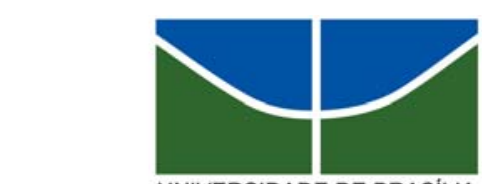

UNIVERSIDADE DE BRASÍLIA

Centro de Excelência em Turismo

Pós-graduação Lato Sensu

Curso de Especialização em Turismo e Desenvolvimento Sustentável

\title{
Turismo em Terra Indígena: o caso da Reserva Pataxó da Jaqueira
}

VICTOR FERRI MAURO

Doutora Tânia Siqueira Montoro

Brasília - 2007 


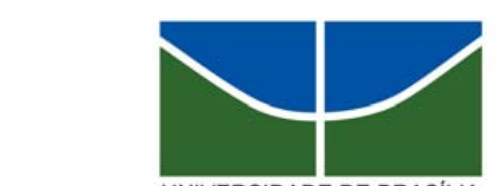

UNIVERSIDADE DE BRASÍLIA

Centro de Excelência em Turismo

Pós-graduação Lato Sensu

Curso de Especialização em Turismo e Desenvolvimento Sustentável

\title{
Turismo em Terra Indígena: o caso da Reserva Pataxó da Jaqueira
}

\author{
Autor: Victor Ferri Mauro \\ Orientadora: Profa. Dra. Tânia Siqueira Montoro \\ Monografia apresentada ao Centro de \\ Excelência em Turismo - CET, da \\ Universidade de Brasília - UnB, como \\ requisito parcial à obtenção do grau de \\ Especialista em Turismo \\ e \\ Desenvolvimento Sustentável.
}


MAURO, Victor Ferri.

Turismo em Terra Indígena: o caso da Reserva Pataxó da Jaqueira / Victor Ferri Mauro. - Brasília, 2007. xvi, 57 f. : il.

Monografia (especialização) - Universidade de Brasília, Centro de Excelência em Turismo, 2007. 112 p.

Orientadora: Tânia Siqueira Montoro.

1.Turismo. 2. Terra Indígena. 3. Reserva da Jaqueira. 4. Pataxó. 5. Sustentabilidade. 


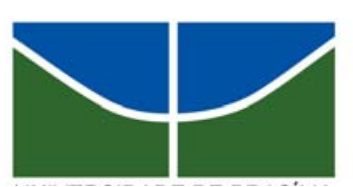

UNIVERSIDADE DE BRASÍLIA

Centro de Excelência em Turismo

Pós-graduação Lato Sensu

Curso de Especialização em Turismo e Desenvolvimento Sustentável

Monografia apresentada ao Centro de Excelência em Turismo CET, da Universidade de Brasília - UnB, como requisito parcial à obtenção do grau de Especialista em Turismo e Desenvolvimento Sustentável.

Aprovado por:

Profa. Dra. Tânia Siqueira Montoro

Departamento de Comunicação - UnB

Prof $^{\text {a }}$. Dra. Iara Lucia Gomes Brasileiro

Centro de Excelência em Turismo - UnB

Prof $^{a}$. Dra. Ellen Fensterseifer Woortmann

Departamento de Antropologia - UnB

Brasília, 08 de maio de 2007. 


\section{AGRADECIMENTOS}

Em primeiro lugar, gostaria de agradecer à minha família, que tanto me incentivou e me apoiou na minha formação. Agradeço também aos professores do curso de especialização em Turismo e Desenvolvimento Sustentável do Centro de Excelência em Turismo da Universidade de Brasília, em especial, à professora Tânia Montoro, pela disposição em orientar este trabalho e pela atenção dispensada. Gostaria ainda de dizer "muito obrigado" aos colegas com quem estive convivendo ao longo desse curso e com quem pude trocar experiências profissionais $\mathbf{e}$ pessoais bastante enriquecedoras. Não poderia deixar de mencionar a minha imensa gratidão à Fundação Nacional do Índio - FUNAI - instituição na qual eu trabalho e que me deu o suporte essencial para que eu pudesse fazer este curso e concluir a presente pesquisa. Sou muito grato também aos vários colegas da FUNAI que colaboraram comigo desde o primeiro momento: ao geógrafo Sandoval Amparo, por ter gentilmente cedido algumas fotos que estou incluindo nos anexos desta monografia; à antropóloga Leila Sotto Maior, por ter cedido fotos, concedido uma entrevista, indicado bibliografia e me ajudado com suas observações pertinentes no momento de construção deste texto; à Karla Carvalho, pela tradução do resumo desta monografia para o Inglês; ao pessoal do GT sobre Turismo em Terras Indígenas, e aos funcionários do Núcleo de Apoio Local de Porto Seguro, sobretudo, ao chefe do Núcleo, Zeca Pataxó, pelo apoio logístico. Para finalizar, deixo registrado aqui meu agradecimento especial aos índios Pataxó da comunidade de Coroa Vermelha e da Reserva da Jaqueira, que tão cordialmente receberam a minha visita e cederam as informações para que pudéssemos realizar nosso trabalho. São muitas as pessoas que contribuíram para que este estudo pudesse ser concretizado. Infelizmente, nem todas é possível mencionar nominalmente aqui. Devo, no entanto, ressaltar que eventuais equívocos e omissões constatados ao longo desta monografia devem ser creditados tão somente à minha pessoa, pois são de minha inteira responsabilidade. 


\section{EPIGRAFE}

Os povos indígenas com sua cultura e seus territórios tentam resistir à extinção não só física, mas também cultural... Até porque a vida é mais que biológica: é um determinado modo de ser, pensar, sentir e agir. Cada vez mais, os povos indígenas afirmam a sua singularidade, a sua diferença, enfim, a sua cultura. Há, portanto, uma existência que poderíamos chamar de objetiva, inspirando o movimento dos indígenas e essa objetividade, sabemos, deriva exatamente de sua afirmação como sujeitos de sua própria História, da sua singularidade.

(Carlos Walter Porto Gonçalves) 


\section{SUMÁRIO}

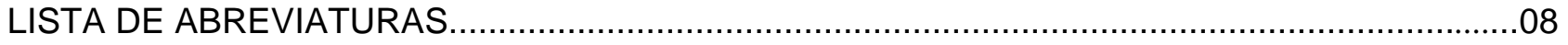

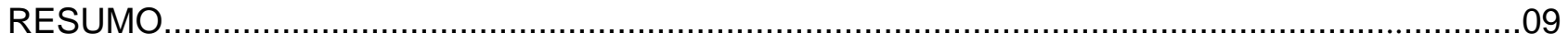

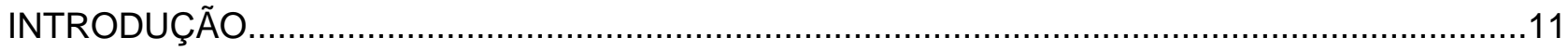

CAPÍTULO 1: O TURISMO ALTERNATIVO E A IDÉIA DE SUSTENTABILIDADE......................15

1.1 - DESENVOLVIMENTO SUSTENTÁVEL: A EMERGÊNCIA DE UM NOVO PARADIGMA.............15

1. 2 - O TURISMO DE MASSA E SEUS EFEITOS NEGATIVOS........................................

1.3 - A ASCENÇÃO DE MODELOS ALTERNATIVOS AO TURISMO DE MASSA..............................20

1.4 - O INTERESSE TURÍSTICO PELAS POPULAÇÕES INDÍGENAS E COMUNIDADES

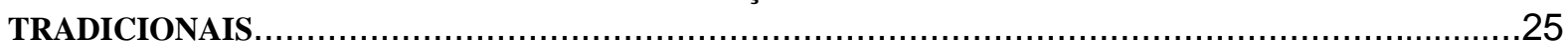

CAPÍTULO 2: SITUAÇÃO LEGAL DO TURISMO EM TERRAS INDÍGENAS.............................29

CAPÍTULO 3: POSSÍVEIS IMPACTOS DO TURISMO EM TERRAS INDÍGENAS........................34

CAPÍTULO 4: PORTO SEGURO: UM DESTINO TURÍSTICO DE MASSA

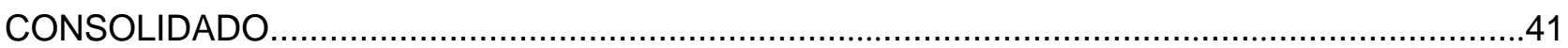

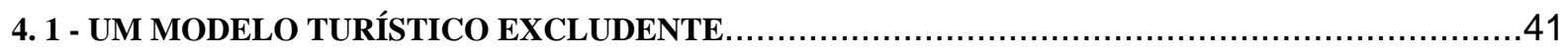

4.2 - INSERÇÃO DOS PATAXÓ NO CENÁRIO TURÍSTICO REGIONAL ...................................46

CAPÍTULO 5: NOTAS ACERCA DO POVO INDÍGENA PATAXÓ.............................................49

5.1 - A PRESENÇA PATAXÓ NA REGIÃO DA COSTA DO DESCOBRIMENTO...............................49

5.2 - MUDANÇAS CULTURAIS E RECONSTRUÇÃO DAS TRADIÇÕES.....................................57

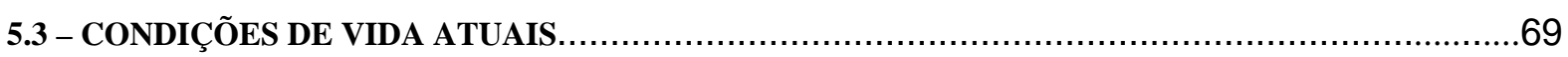

CAPÍTULO 6: O TURISMO NA RESERVA PATAXÓ DA JAQUEIRA......................................74

6.1 - ALGUMAS CARACTERÍSTICAS NATURAIS DA RESERVA........................................74

6.2 - A IMPLEMENTAÇÃO DO TURISMO E SUAS MOTIVAÇÕES.........................................75

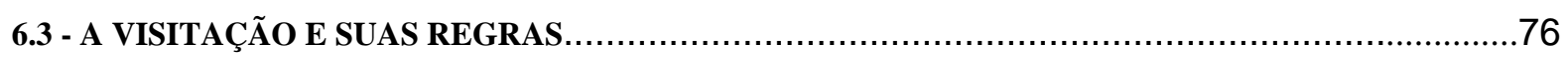

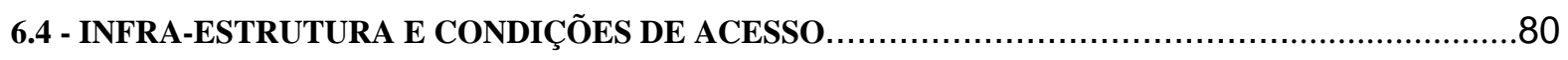

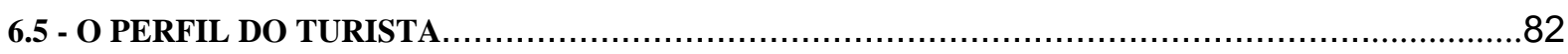

6.6 - PARCERIAS E APOIOS INSTITUCIONAIS PARA A PROMOÇÃO E O

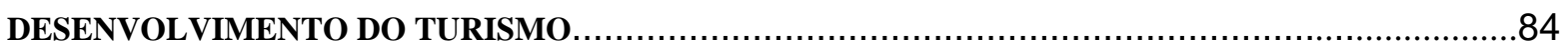

6.7 - GESTÃO DOS RECURSOS E REPARTIÇÃO SOCIAL DOS BENEFÍCIOS...............................87

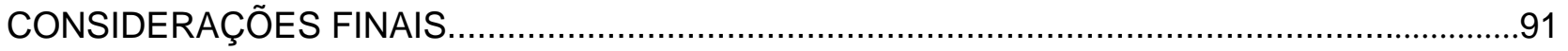

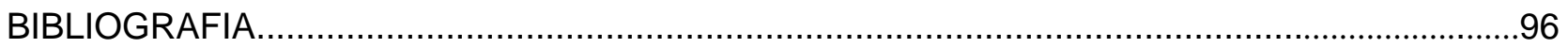

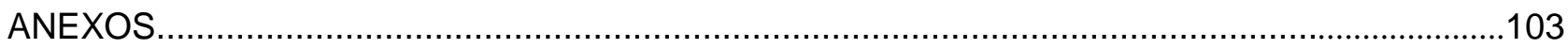

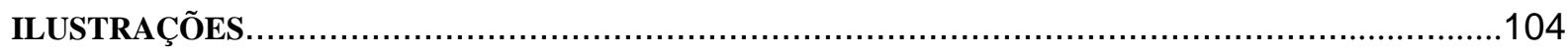

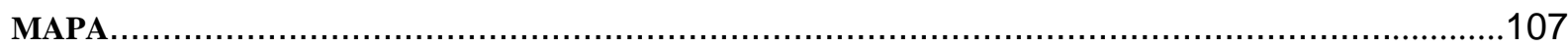

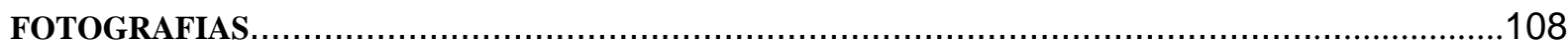




\section{LISTA DE ABREVIATURAS}

ASPECTUR - Associação Pataxó de Ecoturismo

BAHIATURSA - Empresa de Turismo da Bahia S/A

EMBRATUR - Instituto Brasileiro de Turismo

FOIRN - Federação das Organizações Indígenas do Rio Negro

FUNAI - Fundação Nacional do Índio

GTC/Amazônia - Grupo Técnico de Coordenação para a Amazônia Legal

IBAMA - Instituto Brasileiro de Meio Ambiente e Recursos Naturais Renováveis

IBDF - Instituto Brasileiro de Desenvolvimento Florestal (extinto)

ISA - Instituto Socioambiental

MMA - Ministério do Meio Ambiente, dos Recursos Hídricos e da Amazônia Legal

MTUR - Ministério do Turismo

OIT - Organização Internacional do Trabalho

ONG - Organização Não-Governamental

OSCIP - Organização da Sociedade Civil de Interesse Público

PARNA - Parque Nacional

PNMP - Parque Nacional do Monte Pascoal

PROECOTUR - Programa de Desenvolvimento do Ecoturismo na Amazônia Legal

TI - Terra Indígena 


\section{RESUMO}

Há cerca de dez anos, tem se verificado um grande crescimento do envolvimento espontâneo de vários grupos indígenas, das mais diversas regiões do país, na exploração de atividades turísticas, na maioria das vezes, dentro das próprias terras indígenas, e com o consenso, pelo menos parcial, das comunidades ${ }^{1}$. Apesar de as atividades turísticas em terras indígenas não estarem regulamentadas até o momento, são muitas as experiências deste tipo que vêm acontecendo, e ocorrem em contextos e situações bastante diversificados e complexos.

Uma das experiências turísticas desenvolvidas no interior de terras indígenas que está a mais tempo em vigência é a da Reserva Pataxó da Jaqueira, no município de Porto Seguro-BA. Esta Reserva é composta por uma área de 847 ha de Mata Atlântica destinada à conservação. Naquele local, os Pataxó construíram uma aldeia cenográfica, onde desenvolvem um roteiro de visitação ecoturística a cerca de oito anos. Aproximadamente noventa e cinco indígenas estão envolvidos com a exploração do turismo. Eles são membros de uma associação comunitária constituída com a finalidade exclusiva de gerir o empreendimento turístico na Reserva.

O que levou os índios a explorarem o turismo foi principalmente a necessidade de geração de renda para atender certas necessidades da comunidade, mas não se pode desconsiderar nesse processo a motivação em resgatar e valorizar a cultura Pataxó e fortalecer a identidade étnica do grupo, nem se pode deixar de relevar o interesse daqueles indígenas em colocar em prática estratégias de desenvolvimento comunitário que ajudassem a conservar os recursos naturais existentes na reserva.

Em suma, a população Pataxó envolvida com o projeto da Reserva da Jaqueira tem buscado através do turismo, proporcionar condições que levem ao desenvolvimento sustentável da comunidade, e, até o momento, tem sido bem sucedida (pelo menos em muitos aspectos) na busca desse objetivo.

Palavras-chave: turismo, terra indígena, Reserva da Jaqueira, Pataxó, sustentabilidade.

\footnotetext{
${ }^{1}$ Em Lakatos (1991:308) encontramos o seguinte conceito de “comunidade”. “É essencialmente ligada ao solo, em virtude de seus componentes viverem de maneira permanente em determinada área, além da consciência de pertencerem, ao mesmo tempo, ao grupo e ao lugar, e que funcionam em conjunto, no que tange aos principais assuntos de suas vidas. Têm consciência das necessidades dos indivíduos, tanto dentro como fora de seu grupo imediato e, por essa razão, apresentam tendência para cooperar estreitamente”. Consideramos válido o conceito supracitado, no entanto, entendemos que o pertencimento de indivíduo à uma comunidade está mais estreitamente relacionado ao sentimento de pertencimento ao grupo e ao local do que, necessariamente, a sua fixação permanente em determinada área onde concentra-se o grupo. Boa parte dos integrantes da comunidade da aldeia Pataxó de Coroa Vermelha, como veremos em diante, não reside permanentemente naquele local durante o ano todo.
} 


\begin{abstract}
C
During the last ten years it's been noticed a growing interest of the spontaneous interest of several indigenous groups, from different regions of the country, about exploring turistic activities, most of times inside their own indigenous lands, and with the consent, at least partial, of their communities. In spite of the fact that turistic activities inside indigenous lands are not regulated up to this moment, there are lots of experiences of that kind going on, which happen in diversified and complex contexts and situations.

One of the turistic experiences developed inside indigenous lands that is lasting longer is the one going on in the Pataxó da Jaqueira Reserve, in the district of Porto Seguro - Bahia. This reserve is composed of an area of 847 ha of Atlantic Forest, destined to conservation. In this place, the Pataxó built a cenografic village, where for the last 8 years they have been developing a program of ecoturistic visitation. More or less 95 indigenous are envolved in exploring turism. They are members of a community association created with the exclusive finality of managing the turistic enterprise in the reserve.

What led the indigenous to exploring turism was mainly the need to generate income to supply the community needs, but the motivation to value and reafirm the Pataxó culture, strenghtening the ethnic identity of the group should also be considered in the process. It also important to stress the interest of this people to put in practice some strategies of community development that would help to preserve the natural resources found in the village area.

In short, the Pataxó population involved with the project of the Jaqueira Reserve have been looking for providing conditions that lead to the sustainable development of the community through the exploration of turistic activities, and up to this moment they have been well succeed (at least, in many aspects) in the search of this goal.
\end{abstract}

Palavras-chave: turism, indigenous land, Jaqueira Reserve, Pataxó, sustantability. 


\section{INTRODUÇÃO}

O turismo tem sido nas últimas décadas a atividade econômica que vem obtendo os melhores índices de crescimento no Brasil e em vários outros países do mundo.

Devido à saturação de alguns roteiros turísticos de massa e como conseqüência também do aumento da conscientização ecológica da sociedade como um todo, verificada nos últimos 30 ou 40 anos, várias modalidades de turismo alternativas ao modelo "sol e praia" convencional têm despontado. Exemplos disso são: o "turismo de aventura", o "turismo rural/agroturismo", o "turismo cultural", o "turismo étnico", o "ecoturismo", entre outros.

Neste cenário, muitos grupos indígenas brasileiros passaram a explorar em suas terras e fora delas o turismo e atividades relacionadas a ele - em boa parte dos casos, por conta própria e de maneira independente - mesmo não havendo até o momento nenhum tipo de regulamentação para essa forma de turismo. Supõe-se que o principal fator que tenha motivado esses grupos indígenas a se envolverem com o turismo foi a percepção que tiveram da existência de uma demanda específica pela cultura indígena enquanto atrativo e do potencial de geração de renda desta atividade, que poderia ajudar a sanar algumas de suas necessidades econômicas. Dentre os povos indígenas brasileiros que exploram o turismo, os Pataxó aparecem com destaque. Desde a década de 1970 este grupo está relacionado ao circuito turístico de Porto Seguro-BA e região.

Das mais de dez aldeias Pataxó do extremo sul da Bahia, Coroa Vermelha é a que se relaciona com o turismo de forma intensa e direta, embora não seja a única. Esta aldeia é um dos principais atrativos turísticos da Costa do Descobrimento por ficar exatamente na praia onde aportou a esquadra de Cabral no ato do Descobrimento do Brasil. Ali, naquela praia, há anos, os índios montam suas barracas e vendem aos turistas as peças de artesanato que confeccionam. A venda do artesanato constitui a principal fonte de renda das famílias Pataxó de Coroa Vermelha, embora muitos indígenas pratiquem também outras atividades de subsistência. 
Em 1998, um grupo de indígenas provindos da aldeia de Coroa Vermelha fundou uma associação comunitária sem fins lucrativos, a ASPECTUR (Associação Pataxó de Ecoturismo), e a partir daí passaram a explorar o ecoturismo na Reserva da Jaqueira, uma área de aproximadamente 827 hectares de Mata Atlântica, destinada à conservação ambiental, pertencente à Terra Indígena Coroa Vermelha. Este empreendimento ecoturístico continua existindo e hoje em dia são cerca de 95 indígenas que trabalham nele. Os passeios à Reserva conciliam a contemplação da natureza com a apreciação da cultura Pataxó.

Entende-se que as atividades turísticas em terras indígenas precisam ser regulamentadas, pois elas já são realidade há um bom tempo e dificilmente serão revertidas. Entretanto, uma eventual regulamentação da matéria teria, necessariamente, que prever medidas que minimizem os impactos negativos e maximizem os benefícios estendidos às comunidades indígenas, atrelando às experiências turísticas ao cumprimento dos princípios da sustentabilidade, que serão apresentados no decorrer desta monografia.

A Reserva da Jaqueira foi escolhida como objeto deste estudo por ser talvez a experiência turística em terras indígenas mais conhecida do Brasil e melhor consolidada até hoje. Buscamos verificar se ela atende a certos princípios: se o turismo está contribuindo com a proteção da natureza, com a geração de ocupação e renda; se a renda gerada está sendo bem distribuída; se a cultura da população receptora, no caso os indígenas, está sendo respeitada e valorizada; se a comunidade participa dos processos decisórios e da gestão do empreendimento; se os equipamentos e a infra-estrutura existentes são adequados ao uso turístico e se atendem às necessidades, etc. Procuramos também conhecer algumas estratégias de divulgação trabalhadas pela ASPECTUR, as parcerias que são estabelecidas para a viabilização do empreendimento, bem como os órgãos governamentais que prestam algum tipo de apoio.

A maior parte dos dados e das informações aqui mencionados foi obtida através de pesquisa bibliográfica. Foi consultada uma bibliografia razoavelmente extensa que versa sobre o tema do turismo e suas diversas modalidades. O fenômeno do 
turismo na região de Porto Seguro também foi pesquisado. A consulta bibliográfica ainda abrangeu uma série de publicações e documentos que abordam a temática Pataxó, inclusive no que diz respeito à relação desses índios com o turismo, e mesmo sobre o ecoturismo na Reserva da Jaqueira especificamente.

No dia 06 de maio de 2006, por ocasião de um trabalho de campo realizado pela FUNAI, o autor desta monografia esteve na Reserva da Jaqueira acompanhado pelo antropólogo Gilberto da Silva. Tanto um como outro são funcionários do quadro da mencionada instituição. Naquela oportunidade, em conversas com cerca de dez associados da ASPECTUR, foram obtidas informações que, juntamente com as observações feitas in loco, estão constando no teor desta monografia. As conversas que tivemos com os indígenas naquela ocasião não foram gravadas, pois o intuito nosso era deixar os índios mais à vontade para falar. Infelizmente, por falta de tempo durante a permanência em Porto Seguro, não foi possível entrevistar muitas outras pessoas que poderiam prestar informações valiosas para enriquecer este estudo, dentre os quais, o Chefe do Núcleo de Apoio Local da FUNAI, o secretário municipal de turismo, o cacique da aldeia de Coroa Vermelha, além de lideranças importantes e pessoas da comunidade indígena em geral.

Estão inclusas nos anexos deste trabalho, fotografias tiradas pelo seu autor na ocasião da visita de campo. Também constam nos anexos, outras fotos que foram gentilmente cedidas e demais ilustrações.

O primeiro capítulo do trabalho é dedicado à discussão dos problemas gerados pela massificação do turismo e a emergência de modelos alternativos de turismo, verificadas nas ultimas décadas, como conseqüência de uma maior visibilidade mundial para os problemas ambientais e sócio-econômicos.

No segundo capitulo, abordamos a situação legal do turismo em terras indígenas e destacamos a necessidade de uma regulamentação desta atividade, tendo em conta opiniões de profissionais que atuam junto à questão indígena.

No capítulo subseqüente, fazemos apontamentos sobre possíveis impactos (positivos e negativos) que podem decorrer da exploração das atividades turísticas em terras indígenas. 
Entra em analise no quarto capitulo a consolidação do município de Porto Seguro-BA como destino turístico de massa, os efeitos disso para a população local e a relação dos índios Pataxó com este cenário turístico.

No capitulo quinto, fazemos um breve histórico da presença dos Pataxó na região da Costa do Descobrimento, discutimos o processo de mudanças culturais as quais esses indígenas foram submetidos, o fortalecimento de um movimento de resgate e valorização da cultura Pataxó nas ultimas décadas e, por fim, apresentamos as condições de vida atuais desse grupo indígena, dando ênfase aos moradores da aldeia de Coroa Vermelha.

O sexto capítulo é dedicado à descrição do funcionamento do turismo na Reserva da Jaqueira, das parcerias institucionais para a viabilização desse turismo, das estratégias de divulgação adotadas e da gestão do empreendimento propriamente dita.

Finalizamos com as considerações finais, nas quais procurou-se fazer algumas ponderações conclusivas sobre o conteúdo apresentado ao logo de todas as fazes deste trabalho. 


\section{CAPÍTULO 1: O TURISMO ALTERNATIVO E A IDÉIA DE SUSTENTABILIDADE}

\section{1 - DESENVOLVIMENTO SUSTENTÁVEL: A EMERGÊNCIA DE UM NOVO PARADIGMA}

O agravamento dos problemas ambientais e sócio-econômicos em escala global (contaminação dos cursos d'água e do solo, esgotamento dos recursos naturais, desmatamento, poluição do ar, etc.), provocados, sobretudo pelo modelo de desenvolvimento adotado na maioria dos países, fez com que a humanidade acirrasse suas preocupações com a qualidade de vida das gerações presentes e futuras. Dessas preocupações, resultou uma série de convenções internacionais, envolvendo Estados e organizações da sociedade civil, de onde se tirou um conjunto de resoluções e normas e se propôs um novo paradigma de desenvolvimento: o chamado "desenvolvimento sustentável".

A publicação, em 1987, do relatório "Nosso Futuro Comum", da Comissão Mundial sobre o Meio Ambiente e o Desenvolvimento da Organização das Nações Unidas, "foi o catalisador que apreendeu o grande avanço mundial da consciência ambiental" (FIGGIS: 2001). Nesse relatório foram lançadas as premissas de um novo paradigma que viria a ser chamado de "desenvolvimento sustentável", isto é, um modelo de desenvolvimento "que atende às necessidades do presente sem comprometer a possibilidade de as gerações futuras atenderem suas próprias necessidades". (BRUNDTLAND, 1991:46).

A noção de desenvolvimento sustentável reconhece a inadequação ecológica, econômica e social do padrão de desenvolvimento das sociedades contemporâneas (Almeida 2002:25) e se contrapõe a esse padrão hegemônico propondo uma mudança de atitude em escala global, contrariando, muitas vezes, os interesses de grupos econômicos dominantes.

A busca por um novo paradigma de desenvolvimento revela uma mudança de concepção da interação natureza-cultura, que ocorre com segmentos mais conscientizados da sociedade. A crise ambiental teria mostrado as conseqüências nefastas das tentativas do homem em subjugar a natureza ao sabor de sua 
conveniência. Em virtude disso, as pessoas estariam percebendo cada vez mais a necessidade de viverem em equilíbrio com o meio natural, na medida em que estariam passando a se enxergar como parte constituinte da natureza e não mais como um elemento externo á ela.

\section{2 - O TURISMO DE MASSA E SEUS EFEITOS NEGATIVOS}

Para muitos países, o turismo tem sido encarado já há algum tempo como um elemento importante na sua estratégia de desenvolvimento. A atividade é vista como uma alternativa de desenvolvimento econômico na medida em que se tem expectativa de que ela possa atrair divisas para os países, gerar empregos e promover o crescimento regional (WEARING e NEIL, 2001: 33).

Até os anos 1960, os governos da maioria dos países consagrados como destinos turísticos percebia com euforia os resultados econômicos positivos do turismo de massa e deixava de atentar ou não se importava muito com os impactos negativos gerados. Para esses países, sobretudo aqueles situados na periferia do capitalismo, o turismo era tido como uma alternativa promissora que poderia resolver o problema do desenvolvimento interno. $E$ isso acontecia justamente porque a noção de desenvolvimento que se tinha na época superdimensionava a variável do crescimento econômico e subestimava a importância dos aspectos sociais e ambientais.

No Brasil, esse tipo de visão ainda perdura significativamente na mentalidade dos gestores públicos. Estes tendem a enxergar no turismo uma atividade com extraordinário potencial de criação de postos de trabalho, geração de receitas e de arrecadação de tributos, e, muitas vezes, ignoram os impactos negativos de uma expansão turística mal planejada.

Uma questão que parecia estar pouco presente na preocupação desses governos era a de que o turismo massificado, explorado de acordo com a lógica da maximização dos lucros, incentivava e estimulava, na verdade, uma postura de consumo predatório das paisagens e dos recursos naturais, ocasionando impactos extremamente negativos. 
Na realidade, o turismo constituía-se como uma atividade diferenciada que se desenvolvia dentro dos mesmos parâmetros de racionalidade das demais, ou seja, busca incessante a qualquer custo de geração de renda, em detrimento dos recursos naturais e em benefício dos grandes capitais envolvidos na crescente indústria turística internacional. (DIAS, 2003:13-14).

Estimulados pelos agentes que operam esse segmento de mercado, os turistas de massa incorporam um comportamento individualista: ávidos por consumir no menor prazo possível os bens e recursos do destino turístico, sem se envolver profundamente com o lugar visitado e com a população nativa ${ }^{2}$. Esta última, por sinal, acaba sendo sempre a parte mais afetada pelos impactos produzidos pelo turismo de massas, já que ela permanece no local receptor, enquanto o turista retorna ao seu lugar de origem.

Dentre os impactos gerados pela ação de um turismo de massa mal planejado e desordenado, pode-se destacar a poluição sonora, a contaminação dos cursos d'água, o esgotamento de recursos naturais (principalmente a água potável), o desmatamento em função da construção da infra-estrutura turística, a concentração de renda, a exclusão sócio-espacial, o aumento do custo de vida para a população local, o desrespeito com a cultura tradicional das comunidades receptoras, a depredação do patrimônio material e o processo de ocupação desordenada de áreas urbanas (favelização).

As agencias e operadoras que promovem o turismo massificado o poder público local e parte da população receptora, muitas vezes, ignoram a capacidade de carga do destino turístico, isto é, os limites que cada local possui para acolher até uma certa quantidade de turistas sem acarretar a saturação de seu espaço territorial e de seus recursos (físicos, naturais e humanos), desencadeando, com isso, impactos negativos de toda ordem.

Outro problema é que as atrações promovidas pelo turismo massificado, muitas vezes, carecem de autenticidade. São um mero simulacro, e, tão pouco, estão vinculadas à identidade do local visitado e de sua população.

\footnotetext{
2 Por “população nativa” entende-se aqui os moradores que são nascidos ou que residem há muito tempo em uma determinada cidade ou povoado e que possuem um vínculo identitário forte com a cultura daquele local. No caso de Porto Seguro, consideramos como "população nativa” os próprios indígenas e outros moradores tradicionais.
} 
Como afirma Urry (1996:23):

Isolado de um ambiente acolhedor e das pessoas locais, o turismo de massa promove viagens em grupos guiados e seus participantes encontram prazer em atrações inventadas com pouca autenticidade, gozam com credulidade de "pseudo-acontecimentos" e não levam em consideração o mundo "real” em torno deles. Em conseqüência os promotores do turismo e as populações nativas são induzidos a produzir exibições cada vez mais extravagantes para o observador de boa fé que, por sua vez, se afasta cada vez mais da população local.

Para Ouriques (2005), a produção de atrativos turísticos simulados integra uma necessidade que a indústria do turismo tem de produzir o "espetáculo" visando atender ao fetiche do turista em consumir um produto que se cristaliza em imagens exóticas e paisagens cuja relevância é socialmente construída.

Este mesmo autor destaca que, na tentativa de se enquadrarem no estereótipo exigido pela indústria do turismo de massa,

Em várias partes do planeta, comunidades inteiras vêm buscando efetuar o "resgate histórico do passado", de forma a inseri-lo no rol das atrações turísticas. Aliás, fazendo dos hábitos (artificialmente mantidos) e costumes do passado (que há muito deixaram de existir) formas de identidade local. (OURIQUES, 2005: 60).

Não é incomum acontecer a modificação do programa, das atrações e do calendário das festas tradicionais de determinada comunidade em função do mercado turístico, produzindo representações culturais cada vez menos autênticas e mais encenadas de forma espetacular (URRY, 1996). Esse tipo de situação tem afetado inclusive algumas comunidades indígenas brasileiras.

Em muitos casos, a população receptora leva em consideração, em primeiro lugar, o retorno financeiro que se pode auferir da exploração do turismo de massa num plano imediato e não se apercebe rapidamente dos males que a atividade desenvolvida sem sustentabilidade pode provocar. Então, explora-se o turismo continuamente de modo desordenado e mal planejado até que os impactos causados e a degradação da qualidade de vida do local se tornam evidentes. E, uma vez que isso é constatado, o fluxo turístico massivo se redireciona para outros destinos (que igualmente serão degradados), abandonando a população local à própria sorte e deixando de herança para esta última os problemas que o turismo causou ao longo do tempo. 
Segundo Xavier (2006:11):

O turismo de massa causa na população uma sensação de lucro fácil. E quando a mesma não tem preparo para iniciar esta atividade, se deixa levar pelo paradigma do turismo relacionado ao lucro rápido. Só que aos poucos com a saturação do local o turista troca imediatamente de destino, deixando a população em uma difícil situação, já que o seu meio foi "destruído" e não existe um preparo para outras atividades como não houve para o turismo.

O mal planejamento ou a ausência dele no turismo também tem uma enorme capacidade de produzir de forma rápida a descaracterização da sociedade local bem como o rebaixamento de sua auto-estima. Ao lograr esforços no sentido de se adequar aos gostos e costumes dos turistas, a população nativa, com freqüência, tende a mudar - ou pelo menos tentar mudar - seus próprios hábitos, suas preferências, sua visão de mundo, sua fala, seu sistema de trabalho, etc. Não é incomum ocorrer com estes indivíduos uma internalização inconsciente de uma concepção subjetiva que os coloca para si mesmos numa posição de inferioridade em relação ao turista, ocasionando paulatinamente o abandono formas de expressão de sua gente.

Nem todos os indivíduos da população local, no entanto, se esforçam para se ajustar às características desejadas pelo mercado turístico. Podemos dizer até que muitos nativos, principalmente aqueles que pouco ou nada se beneficiam com o turismo, se sentem afetados e invadidos com o intenso fluxo de pessoas estranhas verificado nas épocas de alta temporada.

É importante considerar também aquilo que Ouriques (2005:21) menciona:

É perceptível a visão negativa que muitos visitados têm acerca dos visitantes. Isso, em parte, deve-se ao fato de o período de férias significar, para o viajante, um ritual de inversão, isto é, o turista comporta-se e tem a necessidade de se comportar de forma diferente no local visitado, inclusive agindo de uma forma que se considera socialmente reprovável em sua terra natal.

De fato, alguns turistas convencionais se comportam de modo irresponsável e inconseqüente no local de destino. Sobre isso, Krippendorf (1989:71) afirma:

Longe de casa, o turista se sente enfim livre, não precisa mais atentar para certas normas, pode fazer o que lhe aprouver, vestir-se, comer, gastar, fazer as bagunças que já há tempos queria [...] pelo menos uma vez pode "revelar-se" de verdade. Pouco importa o que os outros vão pensar. 


\section{3 - A ASCENÇÃO DE MODELOS ALTERNATIVOS AO TURISMO DE MASSA}

A crescente conscientização e sensibilização das pessoas quanto aos problemas ambientais e as disparidades sociais, tanto nos países desenvolvidos quanto naqueles em desenvolvimento, ocasionou a partir da década de 80 uma demanda por um "turismo alternativo" ao predominante modelo turístico padronizado e massificado, o chamado por muitos autores de turismo de "sol e praia".

Essa mudança reflete uma transformação de valores e hábitos, encabeçada por pessoas que requerem mais autenticidade no produto turístico que lhes é ofertado. Buscam uma melhor qualidade de vida no contato lúdico com ambientes saudáveis revestidos por paisagens naturais exuberantes e uma maior integração com a comunidade receptora. (DIAS, 2003:16).

De fato, está havendo uma preocupação maior com a sustentabilidade do planeta, e essa noção de sustentabilidade não se limita às questões ambientais, ela abarca todo um conjunto de relações entre o homem e o meio envolvente e dos homens entre si. Nas últimas décadas, a questão da sustentabilidade passou a despertar a atenção também de muitos atores sociais envolvidos com o turismo. A definição da palavra "sustentabilidade" que é mais aceita no meio acadêmico foi formulada por Ignacy Sachs, ela está estruturada em cinco princípios, a saber:

1- Sustentabilidade ecológica, entendida como a proteção da natureza e da diversidade biológica, portanto, o desenvolvimento turístico deve respeitar a capacidade de suporte dos ecossistemas, limitar o consumo dos recursos naturais, e provocar o mínimo de danos aos sistemas de sestentação da vida;

2- Sustentabilidade social, fundamentada no estabelecimento de um processo de desenvolvimento que conduza a um padrão estável de crescimento, com uma distribuição mais eqüitativa de renda, redução das atuais diferenças sociais e a garantia dos direitos de cidadania;

3- Sustentabilidade cultural, implica a necessidade de se buscar soluções de âmbito local, utilizando-se as potencialidades das culturas e o modo de vida local, assim como a participação da população local nos processos decisórios e na formulação e gestão de programas e planos de desenvolvimento turístico;

4- Sustentabilidade econômica, que assegure o crescimento econômico para as gerações atuais e, ao mesmo tempo, o manejo responsável dos recursos naturais, que deverão satisfazer as necessidades das gerações futuras;

5- Sustentabilidade espacial, baseia-se na distribuição geográfica mais equilibrada dos assentamentos turísticos para evitar a superconcentração de pessoas, de equipamentos e de infra-estrutura turísticas e, conseqüentemente, diminuir a destruição de ecossistemas frágeis e a deterioração da qualidade da experiência do turista. (Sachs apud Silveira, 2000:90-91). 
Por "turismo alternativo" costuma se entender de forma genérica uma série de modalidades turísticas que em seus princípios se diferenciam consideravelmente do turismo convencional, de massa. Conforme explicam Wearing e Neil (2001:03), o turismo alternativo compreende "formas não associadas ao turismo de massa em larga escala, sendo, basicamente, de pequena escala, baixa densidade, dispersas em áreas não-urbanas, atendendo ao interesse especial de grupos e pessoas que, essencialmente, apresentam uma educação acima da média e uma renda relativamente alta". Essas formas de turismo "demonstram ser coerentes com os valores natural, social e comunitário e que permitem que tanto hospedeiros quanto hóspedes desfrutem uma interação positiva e conveniente, e compartilhem experiências" (WEARING e NEIL, 2001:04).

Assim sendo, pode-se considerar o turismo alternativo uma terminologia bastante abrangente que abarca modalidades turísticas que proporcionam um maior contato do homem com a natureza e que, em sua concepção, adotam medidas que visam à conservação do ambiente natural, à promoção do bem-estar e à valorização do patrimônio cultural das sociedades envolvidas, não se preocupando unicamente com o lucro, como muitas vezes se pretende o turismo de massa. Dentre as modalidades de turismo que costumam ser classificadas como "alternativas", temos o ecoturismo, o turismo de aventura, o montanhismo, o turismo cultural, o agroturismo, e o turismo científico.

Para Ceballos-Lascuràin (Apud DIAS, 2003:110):

O ecoturismo é aquela modalidade turística ambientalmente responsável, que consiste em viajar a, ou visitar áreas naturais relativamente pouco perturbadas com o fim de desfrutar, apreciar e estudar os atrativos naturais (paisagem, flora e fauna silvestres) dessas áreas, assim como qualquer manifestação cultural (do presente ou do passado) que ali se possa encontrar, através de um processo que promove a conservação, tem baixo impacto negativo ambiental e cultural e propicia um envolvimento ativo e socioeconomicamente benéfico das populações locais.

Na terminologia adotada pela EMBRATUR (1994:19), o "ecoturismo" é:

um segmento da atividade turística que utiliza, de forma sustentável, o patrimônio natural e cultural, incentiva sua conservação e busca a formação de uma consciência ambientalista através da interpretação do ambiente, promovendo o bem-estar das populações envolvidas. 
Tendo em vista os dois conceitos acima expostos, entendemos que é perfeitamente possível classificar a experiência da Reserva da Jaqueira, como ecoturística.

Nas últimas décadas, o ecoturismo, assim como as demais formas alternativas de turismo tem experimentado um crescimento exponencial. Layrargues (2004) mostra que a taxa de crescimento anual do ecoturismo no mundo todo ultrapassa os $20 \%$, e que, no Brasil, anualmente, esta atividade têm gerado cerca de 30 mil empregos diretos e envolvido um fluxo de aproximadamente 500 mil turistas, que têm movimentado em torno de 500 milhões de reais. Segundo este mesmo autor, o crescimento do ecoturismo nos últimos anos está diretamente relacionado à preocupação mundial com a crise ambiental.

A crise ambiental apresentou o mérito de ter afetado, mas não destruído, muitos dos valores do projeto central da modernidade, que se constitui na valoração do artificial em detrimento do natural, que antes era objeto de apropriação e exploração, passa a ser positivamente valorada frente ao panorama de escassez de recursos naturais. [...] Por conseguinte, a nova alteridade natural-artificial provoca novos significados para o viajante que procura o exótico, o diferente. [...] $O$ espaço natural tornou-se o novo objeto de desejo do viajante, imbuído da necessidade de contato e alteridade com as origens, a pureza, a ordem, o ritmo e a estética natural.

Salvati (2001) acredita que há uma tendência crescente dos consumidores de modo geral em verificar se o processo de produção dos produtos que eles consomem respeita os princípios da responsabilidade social e ambiental. Essa tendência de comportamento se aplica também ao praticante do ecoturismo, e do turismo alternativo, de modo geral. De acordo com este mesmo autor, o perfil do ecoturista contém as seguintes características:

- Oriundos de grandes centros urbanos;

- Possuem o cotidiano agitado, estressante e isento de contato com a natureza;

- São ávidos por um contato positivo com o meio ambiente e atividades de relaxamento, contemplação e lazer;

- Procuram acesso á informações sobre o meio ambiente e sobre problemas ambientais;

- Procuram ambientes e culturas diferentes, incomuns e até exóticos, inclusive sobre o pretexto do "antes que acabem";

- Possuem bom nível cultural e educacional (maioria possui nível superior) e financeiro;

- Estão situados na faixa etária de 25 a 40 anos;

- Possuem consciência de que pagam mais caro por programas culturalmente e ambientalmente corretos; 
- São preocupados com a qualidade do ambiente e com a qualidade de vida da comunidade local;

- Alguns postam-se a contribuir, interagindo ou consumindo na comunidade.

Dias (2003:17), afirma que a demanda pelo turismo alternativo "é maior nos grupos sociais identificados com as camadas médias urbanas mais intelectualizadas, que são mais sensíveis às repercussões dos impactos do turismo tradicional no meio ambiente" e enumera uma série de fatores que culminaram no crescimento da demanda por esse tipo de turismo:

- o aumento da consciência da necessidade de preservação dos recursos naturais;

- a necessidade psicológica das pessoas de encontrarem alternativas de lazer diferentes das praticadas nos grandes centros urbanos;

- maior aproximação de formas simples de vida em contraposição à complexidade da vida moderna nos grandes centros urbanos;

- busca de melhor qualidade de vida, que se traduz em maior interação com a natureza. (Idem).

A compreensão do perfil das pessoas que demandam formas de turismo alternativas é um instrumento importante para que os gestores possam traçar estratégias de planejamento turístico e de divulgação dos destinos com vistas a atingir de modo eficiente o público alvo.

Como os roteiros turísticos alternativos costumam ser de pequena escala e baixa densidade, é comum haver uma seletividade do público que se pretende atrair. Essa seletividade costuma ser quantitativa (na medida que se considera a capacidade de suporte dos locais visitados pretendendo minimizar os impactos ambientais e a desestruturação das culturas locais) e qualitativa (ao tentar atrair um perfil de turista que esteja preparado para interagir de maneira respeitosa com a população receptora e que tenha interesse em trocar experiências e adquirir conhecimentos sobre a cultura local).

Para que o turismo se desenvolva em moldes sustentáveis, é desejável que se faça um trabalho de conscientização dos turistas para que os mesmos respeitem as regras de visitação estipuladas e se distanciem da concepção equivocada e arrogante de que o fato de estarem consumindo um produto turístico lhes confere a possibilidade de fazer tudo o que bem entenderem no ambiente visitado. (XAVIER, 2006:13). 
Os agentes envolvidos na promoção e exploração do turismo, principalmente guias e intérpretes ambientais, devem estar aptos para trabalhar a conscientização ecológica dos turistas na ocasião das visitações, através da educação ambiental, transmitindo aos visitantes mensagens que os ajudem a promover uma reflexão, induzindo-os e motivando-os a assumir uma conduta social e ecologicamente responsável. (SALVATI, 2001). O trabalho de conscientização deve ser estendido também à comunidade receptora, para que esta esteja sensibilizada da necessidade - não só econômica, mas também por uma questão de bem-estar social - de se conservar a natureza.

O respeito à capacidade de carga dos locais visitados e o trabalho de educação ambiental são medidas voltadas para a garantia da qualidade do meio natural que asseguram a sustentabilidade do potencial turístico desses locais.

Dias (2003:94) observa que

O turismo, especialmente o voltado para a natureza, está fortemente relacionado com a biodiversidade, particularmente pela atratividade que exercem os ricos e variados ambientes naturais. Ele também pode causar perda da biodiversidade quando a terra e os recursos naturais são pressionados por uso excessivo, e quando os impactos na vegetação, vida selvagem, montanhas, mares e meio ambiente costeiro e recursos d’água excedem sua capacidade de carga. Essa perda da biodiversidade na prática implica perda do potencial turístico.

Além de estar consciente da necessidade da conservação dos ambientes naturais, a comunidade local também deve estar preparada para atuar no processo turístico, sabendo extrair da experiência turística o máximo possível de benefícios para si mesma e para seus clientes.

Segundo Xavier (2006:13):

A população deve aprender a maneira correta de receber o turista, sempre o agradando e sem explorá-lo ou tratá-lo mal, mas deve saber também que é muito importante que mantenha suas características culturais. Deve saber que o lucro rápido através do turismo de massa pode ser bom, mas que o turismo sustentável assegurará sua renda e bem estar por muito mais tempo, conservando o meio ambiente e garantindo saúde às próximas gerações.

Um item fundamental para o sucesso e a sustentabilidade de um empreendimento turístico é a participação efetiva da comunidade local no processo decisório, no planejamento, e na execução do projeto. Tal participação pode fazer com que os benefícios gerados com o advento do turismo contemplem um maior número de 
pessoas, não ficando restritos a um pequeno grupo; pode também assegurar à comunidade o poder e a autonomia de barrar os elementos indesejáveis e promover aqueles que lhes melhor convém.

Segundo Figueiredo (2005:48), uma gestão participativa comunitária do turismo, no que tange ao patrimônio cultural, "pode garantir que os elementos que são representativos para os grupos, e por isso mesmo constitutivos da identidade destes, sejam inseridos na dinâmica da indústria cultural não só privilegiando o lucro, mas também a valorização das peculiaridades do local".

$\mathrm{Na}$ concepção de um projeto turístico, são de vital importância o respeito aos saberes locais, à visão de mundo, aos valores e conceitos, e à ética das comunidades locais. A imposição de saberes e valores externos e de uma dinâmica que não thes é peculiar, pode causar estranhamentos, choques culturais e de interesses, gerando conflitos e dificuldades de relacionamento entre os diferentes atores que compõem o turismo.

Outra condição indispensável para a sustentabilidade de um empreendimento turístico é a capacidade de criar postos de trabalho e gerar renda permanente para as pessoas, sendo que essa renda, ao invés de ficar concentrada nas mãos de poucos indivíduos, deve se estender a uma grande parcela da população local, sobretudo os mais carentes. Uma das formas mais eficientes de obter isso talvez seja a gestão por meio de uma associação comunitária. Atendidas estas condições, os "efeitos multiplicadores" costumam a surtir efeito, na medida em que os trabalhadores do setor turístico e suas famílias passam a consumir uma maior quantidade de bens e serviços, movimentando também outros segmentos da economia local.

\section{4 - O INTERESSE TURÍSTICO PELAS POPULAÇÕES INDÍGENAS E TRADICIONAIS ${ }^{3}$}

Existe uma noção arraigada no senso comum da sociedade brasileira contemporânea de que os índios vivem em harmonia com a natureza e a conservam. Assim sendo, o crescimento do destaque que a questão ambiental tem ganhado nas

\footnotetext{
${ }^{3}$ Lima e Gita (2001:1-3) entendem que o termo “populações tradicionais” pode ser atribuído “àquelas populações não indígenas que, apesar de não terem direitos originários sobre o território, constituem universos culturais específicos, que merecem tratamento cuidadoso para sua abordagem e compreensão”.
} 
últimas décadas, parece ter refletido positivamente na imagem que a sociedade principalmente os cidadãos urbanos - nutre a respeito dos índios.

Uma pesquisa realizada pelo Instituto Socioambiental (ISA) ${ }^{4}$, cuja grande maioria dos entrevistados eram brasileiros moradores das cidades ou regiões distantes das áreas indígenas, revela que $78 \%$ dos entrevistados afirmam ter interesse no futuro dos índios; $88 \%$ acreditam que os índios conservam a natureza e vivem em harmonia com ela; $81 \%$ não os consideram preguiçosos e achavam que eles apenas possuem uma maneira diferente de encarar o trabalho; 89\% acham que os índios não são ignorantes, apenas tem uma cultura diferenciada; também $89 \%$ os consideram violentos, mas só com aqueles que invadem suas terras; $92 \%$ defendem que o direito dos índios viverem de acordo com os seus próprios costumes deve ser respeitado; $67 \%$ discordam que os índios devam ser preparados para abandonar seu habitat e viver segundo os padrões de vida dos não-índios.

Os dados levantados pela pesquisa parecem revelar uma convicção generalizada de que os povos indígenas se encontram numa condição fragilizada e precisam de ajuda para manter boas condições de vida e preservar sua identidade cultural.

Com o crescimento das preocupações ecológicas, segmentos mais conscientizados da sociedade passam a simpatizar cada vez mais com os povos indígenas e com populações tradicionais, se sensibilizando e se envolvendo com suas bandeiras de luta, reconhecendo que estes grupos foram e são ainda, pelo modo de vida que adotam, muito mais eficazes em suas estratégias de conservação da natureza do que a sociedade ocidental. Tal reconhecimento acarreta uma valoração positiva do modo de vida dessas populações, o que acaba por despertar a vontade de muitos indivíduos - citadinos em sua maioria - em conhecer e trocar experiências de vida com um povo indígena, com uma comunidade quilombola ou com grupo de caiçaras, por exemplo.

Figgis (2001), observa que:

Ironicamente, enquanto a diversidade e a integridade das culturas nativas e regiões naturais estavam sob crescente ameaça, viajantes de todo o mundo, educados e conscientes da questão ambiental, buscavam estabelecer contato com elas. Esse tipo de

\footnotetext{
${ }^{4}$ O Instituto Socioambiental é uma OSCIP (Organização da Sociedade Civil de Interesse Público) fundada em 1994, que desenvolve trabalhos referentes á conservação do meio ambiente e questões que envolvem povos indígenas e comunidades tradicionais.
} 
contato 'turístico' trouxe retorno econômico, permitindo que essas comunidades conservassem e celebrassem suas culturas.

Para os adeptos do turismo alternativo, o que faz das populações tradicionais, e mais ainda dos povos indígenas, por si só, um atrativo turístico é justamente a sua diferença, a singularidade que Ihes confere uma identidade própria, autêntica e não simulada e estereotipada. O exotismo étnico dos nativos acaba sendo o próprio objeto de interesse do turista, e, muitas vezes, quanto menor o grau de transformações culturais que determinada sociedade nativa apresenta, maior é a atração que é despertada no turista, pois a compreensão que o turista geralmente tem a cerca das populações tradicionais, e mais intensamente, dos indígenas, está fortemente permeada por uma visão, digamos, "romantizada" do que estes grupos representam.

Seabra (2001:77) é da opinião de que,

[...] localidades potencialmente atraentes para a prática do turismo ecológico, habitadas por povos indígenas, serão tanto mais atraentes quanto mais forem mantidas as características ambientais naturais e sócio-culturais. (Seabra, 2001:77).

Ouriques (2005) entende que os turistas, ao buscarem a experiência do contato com uma sociedade indígena, além de procurar pelo exótico, estão em busca da consumação de um fetiche. Este mesmo autor diz o seguinte:

Quando os turistas [...] ao visitarem localidades onde vivem populações indígenas que não estão trajando vestimentas imaginadas por eles (tangas, pinturas no corpo, cocares, colares etc.) são comuns manifestações de decepção, já que os turistas acham que suas expectativas estereotipadas devem ser confirmadas. $E$ essas expectativas fazem parte das imagens que são vendidas e compradas por eles. (Ouriques, 2005: 110).

Segundo Grünewald (2001), muitas vezes os turistas têm uma impressão negativa a respeito da autenticidade da experiência vivenciada no turismo étnico porque estão acostumados a pensar o fenômeno da aculturação como um fluxo unidirecional, que parte da sociedade complexa para as sociedades tradicionais. "Se soubessem das mudanças conjunturais pelas quais passam os grupos em contato, os turistas os considerariam contextualmente autênticos - afinal, se os nativos têm algo a apresentar, por mais 'descaracterizado' que possa parecer, é porque existe algum fundamento substantivo que pode tornar concreto o elemento cultural apresentado" (Grünewald, 2001:57). 
O autor ainda alerta que, em muitos casos, "a busca pelo exótico está se autodestruindo por causa da influência esmagadora do observador sobre o observado, ou seja, a própria presença do turista torna o nativo menos exótico e tradicional, transformando em um touree, isto é, um ator, que modifica seu comportamento de acordo com a percepção daquilo que é atrativo para o turista - e, querendo ou não, o touree, como objeto de curiosidade, está em exposição, devendo fazer um espetáculo dele mesmo".

Para Grünewald (2001), mesmo persistindo nos Pataxó um certo caráter de tourees, não ocorre entre esses índios a falsificação das suas tradições, mas a criação e renovação constante de elementos culturais em situações de interação social com os turistas. Desta maneira, no caso dos Pataxó, que já estão a séculos em contato com os brancos, a convivência constante deles com os turistas, ao invés de estar concorrendo para descaracterizar a essência da sua cultura, estaria antes contribuindo para a delimitação de sua fronteira étnica e para auto-afirmação de uma identidade coletiva diferenciada. 


\section{CAPÍTULO 2: SITUAÇÃO LEGAL DO TURISMO EM TERRAS INDÍGENAS}

De acordo com a legislação brasileira, as terras indígenas constituem patrimônio da União e são de usufruto exclusivo dos índios. Compete à Fundação Nacional do Índio - FUNAI -, dentre outras ações, exercer a fiscalização e proteção das terras indígenas, além do controle do acesso a elas por parte dos não-índios.

O procedimento regular para o ingresso em terras indígenas requer a autorização por escrito assinada pelo presidente da FUNAI, que só pode ser emitida após consentimento prévio das comunidades indígenas através de seus representantes. Esse tipo de autorização costuma ser concedida apenas no sentido de atender demandas profissionais de pessoas e instituições, tais como pesquisadores, jornalistas, ONG's, missões que desenvolvem trabalhos sociais com as comunidades indígenas, entre outros agentes, não estando previsto até o momento o ingresso para fins turísticos.

Embora o acesso às terras indígenas para fins turísticos não seja regulamentado, nos últimos anos, observa-se o surgimento de diversas experiências de exploração de atividades turísticas nas mais diferentes regiões do país. Estas são promovidas, ora por iniciativa das próprias comunidades indígenas, enquanto uma alternativa de geração de renda; ora se originam de situações em que as comunidades respondem às pressões de agentes do setor turismo, interessados em ter a cultura indígena e/ou os recursos de suas terras como atrativo turístico diferenciado.

O número crescente de solicitações de ingresso em terras indígenas com vistas à prática do turismo encaminhadas à FUNAI na última década revela o aumento expressivo da demanda por essa atividade.

Diante dessa situação, a FUNAI tem recebido cobranças no sentido de definir diretrizes e regulamentos que disponham sobre o ingresso em terras indígenas visando o turismo, estabelecendo assim condições para a pratica da atividade, onde estejam resguardados os direitos indígenas.

As cobranças pela regulamentação da atividade são, muitas vezes, encabeçadas por representantes das próprias comunidades indígenas que vêm explorando o turismo ou que têm interesse em explorá-la futuramente. Na $1^{\text {a }}$ Conferência Nacional 
dos Povos Indígenas, onde mais de seiscentas lideranças indígenas de todo o país estiveram reunidas em Brasília, em abril de 2006, debatendo uma série de temas e apresentando proposições para uma nova política indigenista do Estado brasileiro, foi apresentada e aprovada em plenária a seguinte proposta:

Normatizar o trabalho de ecoturismo feito por povos indígenas ou organizações indígenas, de acordo com $\mathrm{o}$ interesse de cada comunidade, respeitando as especificidades culturais e garantindo recursos necessários para a infra-estrutura, recursos humanos e desenvolvimento da capacidade de gestão de projetos pelas comunidades ${ }^{5}$.

Registros documentais dão conta de que a questão do turismo em terras indígenas é objeto de debate em âmbito governamental desde 1993 e vêm suscitando polêmicas até o presente momento. Reflexo disso é que o órgão indigenista, as comunidades indígenas e demais atores envolvidos não encontraram uma posição consensual e adequada a respeito de procedimentos ou de uma política reguladora da atividade. Enquanto isso, o turismo em terras indígenas vem acontecendo à revelia e sem um controle efetivo por parte da FUNAI.

A falta de um consenso que permeia o debate sobre o envolvimento de indígenas com o turismo fica evidenciada na seguinte explanação de Faria (2005a:74):

O turismo indígena, principalmente o desenvolvimento em terras indígenas, vem promovendo várias discussões e polêmicas junto a lingüistas, antropólogos, geógrafos, indigenistas e indígenas. $O$ cerne da questão reside na presença de turistas, das mais diversas culturas, dentro da terra indígena, o que pode provocar não apenas descaracterização cultural como também perturbar o ambiente natural, o cotidiano das comunidades e promover uma mercantilização da própria cultura. Por um lado, em função desses motivos, ainda há muita resistência para a implantação dessa atividade em terra indígena, onde a relação custo/benefício não é favorável às comunidades, em que os custos ao ambiente e à cultura serão maiores que os benefícios econômicos advindos das atividades turísticas. Por outro lado, mesmo cientes dos riscos dessa atividade, há grupos que acreditam que se o ecoturismo for bem planejado, com participação da comunidade no processo de gestão, com preparação e esclarecimento da população no que se refere à conscientização sobre o turismo e riscos que poderão advir, poderá ser uma alternativa econômica para esses povos.

Em 1995 foi criado um grupo de trabalho interministerial denominado GTC (Grupo Técnico de Coordenação para a Amazônia Legal) sob a coordenação do MMA e com a participação do IBAMA, do Ministério do Turismo, da Embratur, da FUNAI, dos governos dos estados que compõem a Amazônia Legal, associações representantes dos segmentos da economia vinculados ao turismo, organizações

\footnotetext{
${ }^{5}$ FUNADAÇÃO NACIONAL DO ÍNDIO. Conferência Nacional dos Povos Indígenas, em 12 a 19 de abril de 2006, Brasília-DF - Documento Final. Brasília: FUNAI/CGDTI, 2006. p. 29.
} 
não-governamentais e representantes das comunidades locais. O GTC promoveu um workshop em março de 1997 em que foi elaborado o "Programa Piloto de Ecoturismo em Terras Indígenas", onde foram estabelecidos princípios norteadores para o ecoturismo e uma série de critérios para a seleção de áreas prioritárias para o desenvolvimento desta atividade em terras indígenas. Como conseqüência deste último trabalho, o GTC lançou em dezembro do mesmo ano o "Manual Indígena de Ecoturismo", uma espécie de cartilha elaborada para informar e preparar as comunidades indígenas para operações ecoturísticas. De acordo com Melo (2005:70), a presidente da Associação Pataxó de Ecoturismo admite que os índios utilizaram esse manual como norteador para as ações executadas no projeto da Reserva da Jaqueira.

O lançamento do Projeto Piloto e do Manual de Ecoturismo representou um grande avanço das discussões sobre a questão e uma preocupação séria com o desenvolvimento turístico em moldes sustentáveis. Entretanto, muitos anos se passaram sem que os apontamentos levantados pelo Projeto Piloto fossem retomados em discussões sistemáticas que pudessem desembocar numa proposta concreta de regulamentação do turismo em terras indígenas.

Deste modo, a prática do turismo em terras indígenas persistiu carecendo de uma regulamentação, e como conseqüência da falta de legislação regulatória, em alguns casos, a exploração da atividade foi se dando de forma aleatória sem que houvesse qualquer tipo de planejamento estratégico e prevenção de impactos.

Segundo Faria (2005b), a FOIRN (Federação das Organizações Indígenas do Rio Negro), contando com a assessoria de técnicos especializados na área do turismo, realizou entre os dias 16 e 18 de junho de 2004, uma oficina sobre sustentabilidade e ecoturismo indígena, que contou com a presença de representantes de 25 associações filiadas à esta federação. Como resultado da oficina, foi elaborado um guia de ecoturismo indígena para a região do Rio Negro, no Estado do Amazonas, inspirado no Manual Indígena de Ecoturismo, publicado pelo GTC Amazônia em 2007. Faria (2005b) descreve que o guia da região do Rio Negro "é formado por um conjunto de perguntas com temas e conceitos que visam esclarecer as dúvidas 
sobre as vantagens, desvantagens do ecoturismo e informar sobre os conceitos básicos para se desenvolver esta atividade em terra indígena fornecendo subsídios para a elaboração de princípios e diretrizes para o ecoturismo indígena na região".

Por meio da Portaria Presidencial n 179/PRES, de 20 de fevereiro de 2006, a FUNAI institui um grupo de trabalho $(\mathrm{GT})^{6}$ cujo objetivo estabelecido é o de "implementar estudos com vistas à viabilidade na realização de atividades turísticas nas terras indígenas brasileiras". Os trabalhos do GT estão em andamento, e a expectativa é de que os estudos realizados venham a subsidiar uma futura proposta de normatização do turismo em terras indígenas.

A procuradora federal Diana Ribeiro Rocha, em Informação Técnica à Procuradoria Jurídica da $\mathrm{FUNAI}^{7}$, conclui que a Presidência do órgão indigenista têm competência para regulamentar o turismo em terras indígenas e que o instrumento jurídico mais apropriado para tanto seria a Instrução Normativa.

A antropóloga Carmen Junqueira, professora da Pontifícia Universidade Católica de São Paulo, uma das mais conceituadas profissionais que trabalham com a questão indígena no Brasil, defende a opinião de que a FUNAI deve tomar a iniciativa de buscar uma regulamentação para o turismo em terras indígenas que estipule critérios rigorosos para o funcionamento desta atividade, em observância aos princípios da sustentabilidade. Em entrevista para a revista Brasil Indígena, ${ }^{8}$ publicação trimestral editada pela FUNAI, Junqueira discorre sobre a situação atual dos índios moradores do Parque Indígena do Xingu. Mostrando preocupação com o envolvimento de certas populações do Parque com fenômeno do turismo, que tem se dado nos últimos anos, a autora faz uma analogia entre a situação do turismo e a questão da retirada ilegal da madeira e observa que a proibição em si não resolve o problema, é preciso criar alternativas de subsistência para as comunidades.

Quando os índios começaram a ser cooptados, principalmente onde tinha madeira de lei para ser retirada, a gente - me refiro a antropólogos e à Funai - vinha com essa história de que não podia tirar madeira. Mas também não oferecia uma alternativa. Nós nos eximíamos de discutir o problema. $O$ resultado foi que os índios foram cooptados pelas madeireiras, pelos fazendeiros, por empresários e nós perdemos essa batalha. Agora, há algum tempo, os índios estão falando em turismo em terra indígena.

\footnotetext{
${ }^{6} \mathrm{O}$ autor desta monografia é um dos membros do referido GT.

${ }^{7}$ ROCHA, Diana Ribeiro. Informação no 170/CAA/PGF/PFE-FUNAI/2006. Processo no 08620.0812/PJ-FUNAI/2006.

${ }^{8}$ FUNADAÇÃO NACIONAL DO ÍNDIO. Brasil Indígena. Ano III, n 3, jul./ ago./ set de 2006.
} 
Se não fizermos nada a respeito, nós vamos ficar mais uma vez melindrados. Eu acredito que a Funai tenha condições para encontrar uma solução para isso ${ }^{9}$.

A antropóloga então faz recomendações de como esse turismo poderia funcionar de maneira que os impactos negativos fossem minimizados:

O turismo não pode ser aleatório. Não pode ter drogas nem lixo. Tem de ser profissional. Outro ponto importante é a participação de toda a comunidade, por meio de representantes. As decisões não devem ficar restritas a um grupo pequeno de grandes líderes. O lucro deve ser bem dividido. Para o turista, é preciso fazer algumas coisas também - primeiros-socorros, pessoas capacitadas para esse tipo de atendimento, verba para a reposição de medicamento. Isso tudo só se consegue com oficinas. Ainda assim, seria necessário ter uma pessoa "volante", que fosse às aldeias de tempos em tempos para observar o andamento do projeto. Esse tipo de acompanhamento é necessário ${ }^{10}$.

Uma modalidade turística que vêm sendo praticada no interior de algumas terras indígenas ${ }^{11}$ (mas não nas terras Pataxó) e que dificilmente será regulamentada em curto prazo é a pesca esportiva. Existe neste caso uma impossibilidade jurídica, que poderia ser revertida somente com uma alteração na legislação federal - atribuição que compete exclusivamente ao Congresso Nacional -, pois no artigo 18, em seu inciso $1^{\circ}$, da Lei $6.001 / 73$ está colocado que, em terras indígenas "é vedada a qualquer pessoa estranha aos grupos tribais ou comunidades indígenas a prática da caça, pesca ou coleta de frutos, assim como de atividade agropecuária ou extrativa". Nota-se que a lei não estabelece distinções entre os tipos de caça e de pesca. Deste modo, a proibição legal incide inclusive sobre a pesca esportiva, e a caça enquanto modalidade recreativa.

Por uma série de razões que explicitaremos mais adiante, entendemos que a regulamentação do turismo em terras indígenas é a solução mais plausível, e somos levados a concordar com Faria (2005b) no seu entendimento de que "o ecoturismo é a modalidade turística mais adequada a ser desenvolvida nas terras indígenas, tendo em vista o planejamento e a gestão participativa e comunitária dos grupos/comunidade indígena envolvida, que promova a interação entre natureza e comunidade com vistas a uma utilização sustentável e conservacionista do patrimônio natural e cultural indígena, proporcionando melhoria na qualidade de vida dessas comunidades sem causar impactos negativos à sua territorialidade".

\footnotetext{
${ }^{9}$ Idem, p. 16

${ }^{10}$ Idem.

${ }^{11}$ Sobre esse assunto, ver Lustosa, 2006.
} 


\section{CAPÍTULO 3 - POSSÍVEIS IMPACTOS DO TURISMO EM TERRAS INDÍGENAS}

O GTC AMAZÔNIA, na publicação denominada "Manual Indígena de Ecoturismo" (1997:02) conclui que:

O ecoturismo pode ser uma alternativa econômica viável com benefícios diretos e indiretos para as comunidades indígenas envolvidas, como também, um instrumento de resgate cultural, a cosmovisão, a magia e os mitos desses povos, os principais atrativos para o ecoturista. Este é um potencial que está em todas as culturas indígenas do Brasil, em muitos casos desvalorizados e depreciados, que pode e deve ser apresentado como um recurso de inestimável valor. [...] atendendo a crescente pressão interna dos índios e a demanda externa pelo ecoturismo em terras indígenas, o que tem provocado visitas informais e sem controle [...].

No entanto, é preciso atentar que a exploração da atividade turística pode trazer impactos tanto positivos quanto também negativos para as comunidades indígenas envolvidas. Isso vai depender de uma série de fatores, dos quais nem todos são facilmente previsíveis e controláveis. Alguns impactos, uma vez instaurados, são de difícil reversão em curto prazo, principalmente aqueles que trazem malefícios. Até por isso, endossamos a opinião de que uma regulamentação que possa surgir para as atividades turísticas em terras indígenas tem necessariamente que ser bastante criteriosa e responsável.

A exploração do turismo em terras indígenas pode realmente ser uma atividade capaz de gerar desenvolvimento sustentável para as comunidades envolvidas em alguns casos. Para que isso aconteça, é indispensável que uma série de fatores sejam observados. O "Programa Piloto de Ecoturismo em Terras Indígenas" estipula os seguintes princípios que devem nortear a atividade:

- O Ecoturismo deverá levar em conta o grau de contato da sociedade indígena;

- A participação efetiva da comunidade em todo o processo, cabendo à sociedade indígena a gestão do Ecoturismo em suas terras;

- A tradição indígena deve prevalecer sobre os interesses do turismo;

- O Ecoturismo deve respeitar e valorizar a cultura local;

- O uso sustentável dos recursos naturais deve ser incentivado;

- O Ecoturismo deve gerar recursos econômicos que ajudem a melhorar a qualidade de vida das populações envolvidas;

- O Ecoturismo deve ser uma atividade complementar e de apoio às atividades tradicionais.

A seguir, comentaremos superficialmente os itens acima elencados. 


\section{Grau de contato da sociedade indígena}

Como o turismo envolvendo indígenas é um fenômeno muito recente no Brasil, não se tem até o momento um número suficiente de estudos que mensurem os impactos que a atividade tem causado. Entretanto, considerando os impactos que o contato com as frentes de expansão econômica da sociedade nacional causaram para os povos indígenas ao longo dos anos, é possível imaginar que em comunidades que se encontram num estágio de pouco e médio contato com a população não-indígena, o turismo pode produzir efeitos bastante nocivos (sobretudo para os seus costumes e sua cultura), principalmente se não houver um planejamento adequado. Nas comunidades indígenas que possuem um grau avançado de interação com sociedade nacional, como é o caso dos Pataxó, por haver um nível de conhecimento maior dos códigos e dos valores da sociedade não indígena, os impactos negativos do turismo podem ser mais facilmente controlados e minimizados. A atividade pode até trazer muitas conseqüências positivas, auxiliando inclusive esses povos a promoverem o resgate de suas tradições.

O antropólogo Gilberto da Silva, coordenador do Grupo de Trabalho sobre Turismo em Terras Indígenas da FUNAI percebe diferenças nos impactos que o turismo pode causar em se considerando o grau de contato de cada grupo indígena.

Sabe-se que existem comunidades que apresentam um alto grau de interação social com não índios, porém, existem outras que possuem raro contato e, neste caso, uma idéia de turismo coloca em risco seu bem-estar físico, econômico, psíquico e sociocultural. Daí a necessidade de uma avaliação qualitativa de todos os povos indígenas existentes no país um estudo de casos. ${ }^{12}$

Gorgulho (2002) aponta o turismo como uma possibilidade de desenvolvimento para comunidades indígenas, mas faz ressalvas quanto ao grau de contato delas:

[...] temos que encontrar alternativas de auto-sustentação dos povos indígenas para que eles, pela educação, pela saúde, pela produção de alimentos e pela exploração de seus recursos naturais, inclusive o turismo, levando em conta o seu estágio de contato com a civilização, possam conseguir o bem estar e a liberdade.

Este mesmo autor, ciente dos riscos que podem advir da exploração do turismo pelas comunidades indígenas e da necessidade de um bom planejamento para esta atividade, faz a seguinte ponderação:

É um turismo que precisa ser bem ordenado, pois gera impacto negativo forte. Não só pela questão de doenças, costumes e hábitos dos brancos que atingirão as aldeias, como o

\footnotetext{
${ }^{12}$ FUNAI - Informação no 128/CPTI/CGPIMA/2005, de 03 de dezembro de 2005.
} 
consumismo, a destinação do lixo, a disputa pelo dinheiro, mas até mesmo a produção de alimentos pode ser afetada pela supervalorização da produção do artesanato (GORGULHO, 2002).

\section{Participação comunitária na gestão}

Para que experiência turística ocorra de maneira sustentável é indispensável que a comunidade tenha participação na gestão do empreendimento e na tomada de decisões que os afetem. São os próprios índios que devem estabelecer as regras de visitação. São eles próprios que devem gerir os recursos e decidir as prioridades do que será apresentado na arena turística. Inclusive, o envolvimento das mulheres indígenas no empreendimento deve ser estimulado, respeitando-se os costumes de cada grupo étnico.

Acredita-se que as experiências turísticas em terras indígenas em que a iniciativa de explorar a atividade parte das próprias comunidades indígenas, sem muita interferência de agentes externos, tem maiores chances de serem mais bem sucedidas, pois nesses casos é mais provável que haja um comprometimento maior da comunidade com o projeto. Seria interessante, no entanto, que órgãos do governo e ONGs promovessem a capacitação dos indígenas para atuar no negócio e prestassem assessoria às comunidades. Os casos em que o turismo vem sendo explorado por intermédio de empresários e outros agentes externos à comunidade são mais preocupantes, pois isso pode causar a dependência econômica e política dos indígenas em relação a esses agentes - acarretando inclusive modificações nos seus usos e costumes em função das imposições de uma visão mercadológica - e atrelar forçosamente os índios num sistema de trabalho com regras diferentes das quais estão acostumados, sobretudo, em se tratando de grupos com menor grau de contato. Dentre outros impactos negativos, a interferência de agentes externos na gestão do turismo poderia impor modificações no calendário das festividades indígenas; introdução de elementos externos nos traços culturais apresentados ao turista em detrimento da desvalorização dos elementos da cultura tradicional; imposição de uma jornada de trabalho inadequada aos costumes indígenas; relações de trabalho exploratórias, onde os empresários aufeririam lucros substanciais e a comunidade usufruiria uma pequena parte, etc. 
É desaconselhável o desenvolvimento do turismo em comunidades em que há fortes cisões internas e faccionismos, principalmente quando se pressupõe que a exploração da atividade poderia ser foco de polêmicas e acirramento de brigas e divergências.

\section{$\underline{\text { Valorização das tradições e da cultura indígena }}$}

O turista consciente não esta interessado em simulacros; ao contrário, ele valoriza a autenticidade da experiência vivenciada. Por isso mesmo, nos roteiros ecoturísticos em terras indígenas a espontaneidade da cultura e a tradição indígena devem prevalecer sobre outros interesses, justamente porque elas compõem o diferencial da experiência turística daquele local.

A experiência turística deve ser utilizada para a transmissão de conteúdos que enriqueçam os conhecimentos do turista a respeito das tradições indígenas e que o façam ter uma percepção mais positiva a cerca do modo de vida diferenciado que os índios adotam.

O tempo de permanência do turista em território indígena é outra questão importante. Não é aconselhável que o prazo seja muito prolongado, pois quanto mais tempo os turistas permanecem no local visitado, maior é a influência que eles exercem sobre o modo de vida e os costumes da comunidade.

O turismo acarreta a convivência constante da população local com pessoas vindas "de fora" com hábitos de consumo diferentes, tais como: vestuários, alimentos, bebidas, ou, até mesmo, o uso de entorpecentes. Muitas vezes, indivíduos da comunidade anfitriã se sentem atraídos pelos produtos e inovações que são introduzidos na sua realidade pelos turistas e passam a deseja-los, porém, tendo ciência de que para eles esses bens são dificilmente acessíveis. Tal fenômeno pode produzir um rebaixamento da autoestima da comunidade receptora e um sentimento de inferioridade em relação aos visitantes.

\section{Uso sustentável dos recursos naturais}

O uso sustentável dos recursos naturais deve ser incentivado, assim como, deve-se aproveitar as ocasiões dos passeios nas áreas naturais para se fazer um trabalho de educação ambiental junto aos visitantes. Para isso, os guias devem estar bem 
capacitados para transmitir em uma linguagem clara para os turistas, informações sobre a flora e a fauna locais, sobre a serventia de algumas espécies naturais para o uso tradicional da comunidade indígena e sobre a necessidade de se conservar a natureza. Tais informações poderiam também ser repassadas dentro da própria comunidade, aumentando o grau de conhecimento dos próprios indígenas. Os guias turísticos devem estimular o turista a recolher o lixo que produz durante o passeio onde não houver postos de coleta ao longo do percurso. Esta medida evita a sujeira e a contaminação da água, do solo e de locais de uso comum, o que poderia trazer doenças. É também função dos guias dissuadir os turistas de alimentar os animais silvestres, já que isso poderia causar mudanças nos hábitos alimentares e o comportamento da fauna.

É também de suma importância considerar a capacidade de carga dos locais visitados, ou seja, a quantidade de pessoas que determinado local pode comportar em cada visitação sem que impactos muito significativos sejam causados. A saturação dessa capacidade pode acarretar danos ecológicos sérios e com efeitos duradouros, implicando na perda da biodiversidade e, conseqüentemente na deterioração do potencial turístico local. O barulho provocado pelo excesso de turistas circulando na mata, por exemplo, poderia afugentar e estressar os animais silvestres, acarretando modificações nos seus hábitos e comportamentos. Nas trilhas, o pisoteamento contínuo tenderia a provocar impactos na vegetação e no solo: queda ou dano nas hastes ou caule das plantas; redução do vigor das plantas; redução da capacidade de regeneração da vegetação; ocorrência da perda da cobertura do solo; alteração na composição das espécies; perda da matéria orgânica, redução da porosidade e aumento da impermeabilidade do solo; aceleramento do processo de erosão (DIAS, 2003:93).

Outro fator importante para a conservação da natureza é que a possibilidade de obtenção de renda através do turismo pode inibir o engajamento de indígenas na exploração de atividades econômicas muitos mais degradantes para o meio ambiente, como a mineração, a extração de madeira, a caça e a pesca predatórias, o tráfico ilegal de animais silvestres, dentre outras. Sobre esse aspecto, havemos de concordar com a opinião de Baggio (2006:11) quando o mesmo faz a seguinte afirmação:

Os ecoturistas apreciam a paisagem, o conhecimento da flora e da fauna, o estudo geográfico e geológico, o contato com rios e cachoeiras, especialmente quando estes representam um ícone regional, nacional ou internacional. Essa demanda dos ecoturistas poderia conduzir aquelas comunidades indígenas dependentes da exploração 
desordenada e limitada dos recursos naturais a reconstruírem a consciência ecológica que lhes foi roubada por meio do Capitalismo.

Uma outra questão preocupante é a do risco de acontecer a "biopirataria", ou seja, contrabando do patrimônio genético (plantas, sementes, animais, etc.) e a apropriação indevida dos conhecimentos tradicionais associados à biodiversidade. Sabe-se que os povos indígenas assim como outras comunidades tradicionais (quilombolas, ribeirinhos, caboclos, caiçaras, etc.) detém conhecimentos sobre a funcionalidade de diversas espécies da natureza, inclusive sobre o seu potencial medicinal; conhecimentos estes que, muitas vezes, são transmitidos oralmente de geração em geração, dos quais, porém, não existem registros documentais em nenhum lugar. Já ocorreram inúmeras vezes casos em que pesquisadores e cientistas aprendem esses conhecimentos, descobrem os princípios ativos das espécies e registram em seu nome, quase sempre fora do país. Essas "descobertas", muitas vezes, trazem um retorno financeiro significativo para quem detém o registro de patente, mas nem sempre a comunidade detentora do conhecimento tem acesso à repartição de benefícios. Sendo assim, a biopirataria, além de trazer prejuízos ambientais, provoca injustiças do ponto de vista econômico. Com a liberação da prática do turismo em terras indígenas, as condições de acesso a essas unidades ficariam mais facilitadas. Com isso, se teria um risco maior da ocorrência da biopirataria. A comunidade receptora, principalmente os guias, deveriam então ser capacitados e ficar bastante alerta, fiscalizando os visitantes e os alertando para que estes não retirem nenhuma amostra do ecossistema.

\section{$\underline{\text { Turismo como atividade complementar na geração de recursos econômicos }}$}

A implementação do turismo pode trazer benefícios econômicos, gerando postos de trabalho e renda complementar para populações indígenas que se encontram em condições de carência. Contudo, é preciso ressaltar que mesmo nos casos mais bem sucedidos, a exploração do turismo e atividades correlatas não é capaz de por si só garantir uma subsistência digna a um grande número de pessoas. Por isso mesmo, o turismo deve ser visto como uma alternativa complementar a outras atividades econômicas, e não como a única possibilidade, até porque o seu ciclo de desenvolvimento costuma a ser bastante sazonal. Ao abandonarem seus outros afazeres para se dedicar exclusivamente ao turismo, os índios poderiam estar criando uma dependência excessiva e perigosa de uma única atividade que, se abalada, irá 
comprometer todo o sistema econômico comunitário, desencadeando sérias dificuldades de ajustamento.

Deve-se atentar para que os ganhos financeiros beneficiem a comunidade indígena da maneira mais eqüitativa possível, não ficando concentrados nas mãos de um pequeno grupo de pessoas.

A comunidade precisa ter um grau razoável de compreensão do funcionamento de uma economia de mercado, conhecer o sistema de valoração monetária empregado pelo homem branco, para não serem passados para trás, mas também, para não fazerem exigências absurdas dos turistas quanto ao valor dos ingressos cobrados e dos produtos que vendem a eles. Essas noções são importantes também para saberem gerenciar um negócio de maneira sustentável, pensando a médio e longo prazos. É mais fácil alcançar esses objetivos com as comunidades indígenas que se encontram em um grau de integração na sociedade nacional bastante avançado.

Segurança, integridade e satisfação dos turistas

Outra preocupação diz respeito à integridade e segurança dos turistas. Sabe-se que, durante os passeios turísticos, existem riscos de turistas se machucarem, sofrerem acidentes ou serem atacados por animais. Para evitar ao máximo quaisquer incidentes, teria que se evitar ou mesmo impedir a prática em terras indígenas de modalidades esportivas e de lazer que oferecem maior perigo, além de prever medidas de segurança e a presença de equipe médica nas proximidades.

A comunidade indígena deve também estar preparada para receber os turistas com hospitalidade. Trata-los bem, sem ter que bajula-los e transmitir a eles informações sobre a cultura indígena, sobre o meio ambiente e outras que forem necessárias.

Uma vez regulamentadas as atividades turísticas em terras indígenas, para garantir que os danos sejam minimizados e os benefícios sejam maximizados, além haver o planejamento criterioso e eficiente das ações, as experiências turísticas deverão contar com o assessoramento e fiscalização permanente por parte da FUNAl. Resta saber se o órgão indigenista - nas condições em que se encontra, com um orçamento escasso e com um quadro reduzido de funcionários - terá condições de cumprir de modo eficaz essa tarefa. 


\title{
CAPÍTULO 4: PORTO SEGURO: UM DESTINO TURÍSTICO DE MASSA CONSOLIDADO
}

\section{1 - UM MODELO TURÍSTICO EXCLUDENTE}

Consolidado hoje em dia como um dos principais destinos turísticos de massa no Brasil, Porto Seguro foi um lugarejo bastante pacato antes da conclusão das obras da principal rodovia que dá acesso à cidade, a BR-101, em 1974.

De acordo com Aguiar (2003:13):

\begin{abstract}
Porto Seguro, antes da abertura da estrada BR-101, era um pequeno município que vivia, principalmente, da agricultura e da pesca, encontrando-se também bastante isolado, uma vez que o péssimo estado de conservação das estradas impedia o fluxo de automóveis e a maior parte do comércio e dos transportes era realizada a partir de pequenos barcos que atracavam no porto. [...] A energia elétrica era produzida em geradores e não havia na cidade sistemas de água e esgoto.
\end{abstract}

No ano de 1967 se deram as primeiras iniciativas no sentido de transformar Porto Seguro em um pólo turístico com a promoção de excursões e a divulgação do município. Entretanto, somente um pouco antes da inauguração da rodovia BR-101 é que começa haver um afluxo turístico mais constante no local. A maior parte desses visitantes era composta por jovens idealistas à procura de paisagens exuberantes e de contato com a natureza. Outros tantos procuravam fixar residência no local no anseio de levar uma "vida alternativa". (AGUIAR, 2003:13).

Com a inauguração da BR-101, que facilitou as condições de acesso à região, começaram a afluir para lá uma série de empreendimentos que provocaram sérios impactos sócio-ambientais. Trata-se, principalmente, de madeireiras, serrarias e fazendas de criação de gado (ROCHA JúNIOR, 1987:39).

A facilitação do acesso através da abertura da BR-101, somada á intensificação da divulgação de Porto Seguro como destino turístico, atraiu um número bem maior de turistas, os quais possuíam um perfil bem diferente do visitante que freqüentava o local até então. Porto Seguro e os pequenos lugarejos ao seu redor passaram a atrair turistas com um poder aquisitivo relativamente elevado, oriundos de outras regiões do país - principalmente do Sudeste - e também de outros países. A valorização turística da região atraiu também comerciantes e empresários vindos de fora, inclusive, pessoas que tinham a intenção de especular com a compra de 
imóveis (GRÜNEWALD, 2001:25). A chegada desses novos agentes trouxe para a região novos estilos vida e de comportamento, que em princípio causaram estranhamento para a população que tradicionalmente a habitava (ROCHA JÚNIOR, 1987:40).

Além das praias e outras belezas naturais, o conjunto arquitetônico histórico da cidade, tombado pelo IPHAN em 1973, compunha outro fator de atração do turismo.

$\mathrm{Na}$ década de 90, o turismo já se tornara a principal atividade econômica local. Segundo dados da Embratur citados por Grünewald (2005:131), em 1998, Porto Seguro se consolidara como segundo maior pólo turístico do Estado da Bahia, atrás apenas de Salvador, sendo também a sétima cidade brasileira mais visitada por turistas nacionais. Os turistas estrangeiros, sobretudo os argentinos, também se faziam presentes em grande número. (BURMAN e SANTANA, 1992:66).

É também nos anos 90 que, não só Porto Seguro, como outras cidades que compõem o circuito da Costa do Descobrimento (Santa Cruz Cabrália e Belmonte) apostaram fortemente na sua vocação turística. Por meio do PRODETUR (Programa de Desenvolvimento de Turismo no Nordeste), que consiste em uma parceria entre o governo brasileiro e o BID (Banco de Interamericano de Desenvolvimento) esses municípios receberem investimentos da ordem de US\$73,564 milhões. (SILVA e FERNANDES, 2005).

Foram aplicados recursos significativos na implementação e adaptação de infraestrutura nessas cidades. Segundo Silva e Fernandes, "o aeroporto de Porto Seguro foi ampliado, a cidade ganhou sistema de tratamento de água e esgotamento sanitário, trechos de rodovias foram construídos".

Grande parte dos investimentos foi aplicada também no marketing e na divulgação dos destinos turísticos.

O desenvolvimento turístico de Porto Seguro, no entanto, atraiu para a cidade uma grande corrente migratória que fez com que sua população crescesse em ritmo vertiginoso nos últimos 15 anos. Para se ter uma idéia, segundo dados do IBGE, em 1991, o município era habitado por 34.661 pessoas; em 2005, as estimativas do IBGE calculavam a população local em 133.976 habitantes. Tendo como referência dados do IBGE, Muricy (2001:191) demonstra que os municípios de Porto Seguro e 
Santa Cruz Cabrália, onde situam os limites da Terra Indígena de Coroa Vermelha, são os que registraram maiores taxas anuais de crescimento demográfico na Bahia entre os anos de 1991 e 2000, respectivamente 11,94\% e 15,49\%.

Boa parte desse afluxo de pessoas que se instalaram em Porto Seguro e região nas últimas décadas é preenchido por migrantes provenientes das lavouras cacaueiras do sul da Bahia, que enfrentara uma crise por causa dos ataques de uma praga conhecida como "vassoura de bruxa". Com o prejuízo nas plantações, cerca de 200.000 trabalhadores ficaram sem emprego, migrando para cidades da região, atraídos pelas possibilidades de empregos permanentes, temporários e ocupações na economia informal relacionada ao turismo, aglomerando-se nas áreas periféricas.

Em Porto Seguro, já havia um grande déficit habitacional que se acumulara ao longo dos anos e a cidade não estava preparada para abrigar a nova onda migratória. Assim, os novos habitantes da cidade abrigaram-se em casebres feitos da noite para o dia em qualquer local que estivesse desabitado, sobre mangues e encostas de morros nas periferias da zona urbana, sem o mínimo de planejamento (ARAÚJO apud SILVA e FERNANDES, 2005).

De acordo com Almeida Neto, Gottschall e Cypriano (1997:17), citados por Silva e Fernandes (2005), dentre os impactos negativos gerados em Porto Seguro ao longo dos últimos anos em decorrência da migração e da concentração populacional, destacam-se: a falta de controle sobre os novos assentamentos; a favelização; a invasão de terras privadas ou inadequadas para urbanização; a superprodução de esgoto e lixo e conseqüente poluição; o crescimento exagerado do comércio informal com degradação do comércio formal; a sobrecarga da infra-estrutura existente; a massificação das áreas de lazer e praias; o declínio da auto-estima da comunidade local e a sua desestruturação social, além da incapacidade de gestão do problema por parte do poder público municipal.

Mendonça Júnior, Garrido e Vasconcellos (2001:118) asseveram que:

A descoberta de Porto Seguro pelos grandes operadores turísticos nacionais fez surgir um novo segmento, o do turismo de massa, crescendo com ele o número de novos e maiores empreendimentos hoteleiros, que passaram a exercer forte pressão sobre a infraestrutura básica. Esta, por sua vez, não tinha capacidade para suportar a demanda hoteleira, nem para atender às novas necessidades advindas da expansão populacional.

A urbanização desordenada de Porto Seguro, em conseqüência da falta de planejamento e da incapacidade da cidade em absorver adequadamente o 
contingente que migrava para lá assim como os novos empreendimentos que iam surgindo, produziu uma série de impactos ambientais, econômicos e sociais danosos, que fez decair a qualidade de vida local, surtindo efeitos negativos principalmente sobre a população mais pobre.

Segundo Silva e Fernandes (2005):

Do ponto de vista ambiental, a urbanização desordenada e especulação imobiliária ligada ao turismo de massa comprometeram até hoje a maioria dos ecossistemas costeiros da Costa do Descobrimento, riquíssimos em diversidade biológica. A maior parte das restingas e brejos costeiros foram, e ainda estão sendo, substituídos por empreendimentos hoteleiros, condomínios turísticos, centros de show e barracas de praias. Áreas de mananciais, florestas e manguezais estão, por sua vez sendo aos poucos invadidos por loteamentos habitacionais populares e de classe média, bairros de periferias e favelas.

Além da destruição dos ecossistemas, este processo de ocupação alterou grande parte das paisagens mais próximas a Porto Seguro e Santa Cruz Cabrália, comprometendo irreversivelmente a sua beleza e atratividade. $O$ crescimento populacional exponencial e a pressão demográfica sazonal dos turistas, vêm gerando graves problemas de saneamento, ocasionando inúmeros depósitos irregulares de lixo e a poluição dos lençóis freáticos, cursos de água, e conseqüentemente, das praias mais freqüentadas pelos banhistas.

O afluxo massivo de visitantes na cidade teria ocasionado uma mudança significativa nos costumes, na cultura, e, até mesmo, na fala local. As festividades tradicionais só continuam mantendo sua forma típica nos povoados menores e mais afastados do centro. A cultura original da comunidade local permanece sendo ignorada pelos empresários do turismo, que preferem vender atrativos artificiais e simulados, inspirados na cultura negra da região do Recôncavo Baiano. Esse processo acaba por acarretar danos irreversíveis para a identidade da população nativa ao submetê-la ao engajamento numa exploração turística mercantilizada e artificializada. (SILVA e FERNANDES, 2005).

O patrimônio histórico da cidade também foi atingido por esse processo de massificação turística. Nas casas mais próximas da praia, as fachadas têm sido conservadas com seu estilo colonial, no entanto, o interior dos imóveis tem sofrido alterações que visam adaptar os espaços às novas funcionalidades, para uso comercial. O aumento da circulação de turistas na cidade originou uma intensa especulação imobiliária que ocasionou a retirada quase que total dos moradores tradicionais das casas mais bem localizadas (em sua maioria, pescadores) para dar lugar ao comércio que se instalava ali. (AGUIAR, 2003:15). 
Muricy (2001:184) conclui que:

A falta de planejamento urbano, ou a sua inoperância, fez com que a expansão da cidade se pautasse pela lógica dos grandes empresários (sobretudo do setor turístico e imobiliário) em detrimento da lógica das pessoas do lugar. O predomínio da visão utilitarista e imediatista entre os empresários locais e nas esferas governamentais levou a que diversas agressões ao meio ambiente (como aterramento de lagoas e ocupações de manguezais) e ao patrimônio histórico-cultural fossem cometidas.

Em Porto Seguro, poucos são os nativos que se beneficiam substancialmente do turismo e que participam do seu planejamento e gestão. A maioria se encontra subempregada em ofícios sazonais, que exigem pouca qualificação e que proporcionam baixa remuneração. Encontram-se marginalizados economicamente pelo alto custo de vida (alimentação, aluguel, etc.) impulsionado pela presença de turistas com maior poder aquisitivo. Concentram-se em subúrbios e favelas, vivendo num contexto social de pobreza, criminalidade e violência, onde a prostituição e o tráfico de drogas é uma realidade efetiva, estimulada pelo turismo "festivo" que é promovido na cidade.

O quadro de exclusão da população local com o advento do turismo massificado e de outras atividades econômicas que aportam na região fica evidenciado na seguinte explanação de Rocha Júnior (1987:40):

A população urbana teve que se adaptar à crescente invasão e solicitação de estranhos, e uma série de rearranjos espaciais e ocupacionais se processaram [...]. Novas colocações empregam sazonalmente a população urbana pobre, engrossada pelos posseiros expropriados.

[...] Os pescadores artesanais foram afetados, pois suas pequenas canoas, de troncos cavados, não podem competir com barcos motorizados; os grandes cardumes são dizimados em alto mar e já não chegam tantos peixes próximos á costa, ou na zona de exploração das canoas. A esses pescadores restou a proletarização assalariada, trabalhando para os proprietários dos barcos. $O$ peixe e a farinha, alimentos básicos da população, encareceram sobremaneira.

Os impactos negativos do processo de desenvolvimento turístico que ocorre em Porto Seguro e região também são sentidos entre os Pataxó. A população indígena vive marginalizada, embora, nos últimos anos, venham ocorrendo alguns tímidos esforços no sentido de promover sua integração. Hoje em dia, poucos são os indígenas que preenchem postos de trabalho fixos na cadeia turística instalada na região. A maioria dos índios de Coroa Vermelha, por exemplo, vive quase que exclusivamente em função dos parcos rendimentos proporcionados pela venda do artesanato para os turistas além das atividades de subsistência. 
A dependência quase que exclusiva da economia regional em função de uma única atividade, e que é sazonal - o turismo - faz com que a época de alta temporada turística, sobretudo o verão seja aguardado com muita expectativa pela população nativa, inclusive pelos índios. Para Muricy (2001:187), a alta estação do turismo:

É um período ansiosamente aguardado pela grande maioria dos moradores, que vêem aí possibilidade de melhoria de vida, com o aumento dos rendimentos, é sinônimo de trabalho, mas também de diversão e de festa para boa parte deles.

As forças produtivas da região passam assim a estarem quase que inteiramente concentradas no atendimento das demandas daqueles que vêm de fora.

Agitação e as festas, são a marca registrada do verão de Porto Seguro. Durante o dia, os turistas se concentram nas praias e nas barracas, onde toca axé-music e as pessoas dançam as coreografias da moda. Alguns moradores locais também participam da folia. À noite, o movimento se concentra nos clubes e danceterias. Nesses ambientes ocorre o consumo bastante acentuado de bebidas alcoólicas. Sabe-se que também há consumo de drogas ilícitas, embora este geralmente não se faça publicamente. A prostituição, inclusive de menores, também é uma realidade nada incomum, e que as autoridades locais pouco fazem para coibir.

Muricy (2001:191) é bastante precisa ao diagnosticar que:

O discurso turístico em Porto Seguro se baseia, em grande medida, na promessa de prazer, no desejo instituído, da transgressão, da quebra da rotina. Instalam-se um tempo e um espaço imaginários que correspondem a desejos dos quais as pessoas não podem se ocupar no cotidiano. A disciplina do corpo vai ser alterada, com a permissividade proporcionada pelos espaços da "desordem ordenada", que permitem admirar o exótico, o que é alheio a nossa sociedade, e experimentar situações diferentes, ainda que seja necessário um auto-controle para vivenciá-las.

Diante desse cenário, volta e meia, alguns turistas se excedem em seu comportamento, ainda mais quando estão embreagados, pois já vão para o destino turístico imbuídos daquela idéia de que ali eles terão liberdade para agir de forma diferente de como agiriam no cotidiano das cidades onde moram.

\section{2 - INSERÇÃO DOS PATAXÓ NO CENÁRIO TURÍSTICO REGIONAL}

Há um bom tempo os Pataxó da Costa do Descobrimento se relacionam de alguma forma com o turismo. Segundo Grünewald (2002:211-212) desde o início dos 
anos 1970, por causa de uma estratégia regional de marketing turístico que apelava para o ato histórico do Descobrimento do Brasil, os Pataxó são chamados para fazerem representações de sua cultura em contextos escolares, inaugurações municipais e outros atos políticos.

Para a antropóloga da FUNAI, Leila Sotto Maior ${ }^{13}$, nessas encenações públicas que os índios fazem, por vezes ocorre a banalização da cultura indígena, como no caso da apresentação feita na ocasião do dia do índio em 19 de abril de 2006, quando alguns índios dançaram em cima de um palco montado pela prefeitura na Passarela do Álcool ${ }^{14}$ perante uma platéia de centenas de pessoas.

A praia de Coroa Vermelha, onde está instalada uma aldeia que leva este mesmo nome, por ser uma área de interesse histórico, devido ao fato de ser o local do Descobrimento do Brasil, virou uma das atrações turísticas mais visitadas de Porto Seguro e região. Com isso, os índios que ali viviam e os que foram se instalando no local se entusiasmaram com a possibilidade de comercializar o seu artesanato com os turistas. Embora os Pataxó já façam parte do cenário local, a maioria dos turistas que vão até Coroa Vermelha não se dirige para lá com a intenção de visitar os índios. Muitos deles nem sabem previamente que naquele local habitam indígenas.

A respeito do perfil e das expectativas dos turistas que visitam as cidades da Costa do Descobrimento e das estratégias de marketing e divulgação dos roteiros turísticos adotadas pelo poder público e empresas turísticas da região, Grünewald (2005:131-132) faz a seguinte constatação:

Apesar dos turistas que visitam essas cidades em carros particulares ou que chegam isoladamente de avião ou ônibus, buscando tanto o "agito" ou o "retiro" nos distritos de Porto Seguro, [...] a grande maioria dos visitantes é composta mesmo de turistas charter ou de massa. Mas praticamente todos esses tipos de turistas chegam na região (e dirigemse para os passeios) sem saber da presença indígena, o que só vai acontecer quando deparam com eles [...] ou quando avisados que isso acontecerá, pouco antes do encontro, pois, mesmo com toda a movimentação turística e com a bem marcada presença indígena, nem empresas turísticas nem os municípios de Santa Cruz de Cabrália e de Porto Seguro elaboram projetos turísticos envolvendo os pataxós, que acabam por se configurar como uma curiosidade a mais em passeios como à cruz da primeira missa, na Coroa Vermelha, à cidade histórica de Porto Seguro, à noite na feira hippie da Praça da Bandeira também nessa cidade, ou mesmo como atração final de um passeio recreativo a cavalo de Caraíva

\footnotetext{
${ }^{13}$ Informação fornecida em entrevista realizada no dia 21/12/2006, na sede da FUNAI, em Brasília.

${ }^{14}$ A Passarela do Álcool é um espaço semelhante a um “calçadão” localizado no centro de Porto Seguro, onde funcionam lojas, bares, restaurantes e outros tipos de comércio. É talvez o lugar mais badalado da cidade durante a noite.
} 
até a aldeia de Barra Velha - embora neste caso a aldeia já se configure como uma atração turística em si. (Grünewald, 2005:131-132).

Em um outro estudo publicado, este mesmo autor expõe de forma ainda mais incisiva o pouco destaque que se dá à existência dos Pataxó na divulgação do produto turístico local desses municípios litorâneos do extremo sul baiano:

De maneira geral, as prefeituras de Santa Cruz Cabrália e Porto Seguro não enquadram os Pataxó como atração turística, mas apenas como objeto de curiosidade e venda de souvenires. Não há nenhum plano ou projeto turístico no qual os Pataxó apareçam como referencial histórico ou atração cultural [...]. De modo semelhante, as empresas turísticas não mencionam os Pataxó quando vendem seus pacotes nas grandes cidades (Grünewald, 2001: 39).

Na ocasião de nossa visita a Porto Seguro, em maio de 2006, foi constatado que a prefeitura municipal distribuía panfletos de divulgação turística da cidade contendo um roteiro de visitação em que constava como atração turística a Reserva da Jaqueira. Talvez esse possa ser um sinal de uma progressiva conquista de espaço dos Pataxó no cenário turístico regional.

É bem provável que essa recente divulgação do roteiro da Reserva da Jaqueira faça parte de uma estratégia de enfatizar a diversidade da oferta do produto turístico local. Tal estratégia estaria em consonância com o que está colocado no relatório do Fórum Sócio-ambiental do Extremo Sul da Bahia, de 2003 (p.2) que paradoxalmente, o turismo que está sendo implantado na Costa do Descobrimento visa a "descentralização da atividade turística" e o aumento de demanda por lugares exóticos, "dissociados da experiência cotidiana do cidadão".

O projeto da Jaqueira foi criado para atrair pessoas cuja expectativa é vivenciar a interação com os indígenas e com o seu "modo de vida tradicional". Por isso, o apelo turístico desse empreendimento procura reforçar tal expectativa. No caso de Coroa Vermelha, aldeia sede dos índios que se apresentam na Reserva da Jaqueira, a motivação que leva os turistas a se dirigirem para aquele lugar já nem é propriamente a presença dos índios, mas antes a visitação ao local que simboliza a Primeira Missa rezada no Brasil. Essa pode ser uma explicação provável pela qual os meios de divulgação turística de Porto Seguro trabalham o marketing do turismo indígena com maior ênfase para a Reserva da Jaqueira e nem tanto para a aldeia de Coroa Vermelha. 


\section{CAPÍTULO 5: NOTAS ACERCA DO POVO INDÍGENA PATAXÓ}

\section{1 - A PRESENÇA DOS PATAXÓ NA REGIÃO DA COSTA DO DESCOBRIMENTO}

Os Pataxó atuais costumam se apresentar na arena turística como os descendentes dos índios que receberam a esquadra de Cabral em 1500. No entanto, como observa Sampaio (2000), "a detalhada descrição etnográfica contida na carta de Pero Vaz de Caminha não deixa dúvida de que os índios presentes na ocasião do Descobrimento do Brasil eram, na verdade, da etnia Tupiniquim, que na época habitavam o extremo sul da Bahia". De acordo com Rocha Junior (1987:40-41), este último grupo étnico mantinha a posse de todo o território do litoral da Costa do Descobrimento, repelindo incursões de bandos indígenas, que povoavam as matas do interior (principalmente dos Pataxó) e que esporadicamente os atacavam para saquear suas aldeias e plantações. Ainda segundo este último autor (Idem), posteriormente, os Tupiniquim da região de Porto Seguro "foram [gradativamente] sendo integrados e aculturados, até a sua assimilação total à sociedade regional".

$\mathrm{Na}$ época do Descobrimento, os Pataxó - assim como outros grupos indígenas do tronco lingüístico Macro-Jê como os Maxakali, Kamacã e Botocudos, denominados todos eles genericamente como "Aimorés" pelos não-índios - habitavam as matas próximas ao litoral, dispersos em pequenos bandos de famílias, vivendo de forma seminômade e sobrevivendo da caça e da coleta (Sampaio, 2000).

Baseado em relatos etnográficos produzidos no início do século XIX, Rocha Júnior (1987:41) afirma que:

As florestas do rio Mucuri eram habitadas por Pataxós, organizados em bandos dispersos, com certo grau de diferenciação entre si; alguns mantinham contactos intermitentes - como em Alcobaça, por exemplo - mas a maioria eram isolados e aguerridos.

Registros feitos pelo príncipe de Wied-Newied (MAXIMILIANO, 1989:214) no início do século XIX já identificam uma presença esporádica dos Pataxó em rotas predeterminadas da região do Descobrimento onde estes se encontravam com comerciantes regionais para trocar com eles mercadorias que produziam. Mas, apesar disso, a tônica das relações entre os grupos "Aimorés" e os não-índios eram, 
muitas vezes, hostis. Segundo Sampaio (2000), até o princípio do século XIX, eram freqüentes os ataques desses índios as capitanias de llhéus e Porto Seguro, onde saqueavam as populações locais e destruíam suas casas e plantações, até que o governo imperial, preocupado em estabelecer rotas terrestres de ligação entre o Rio de Janeiro, as minas e a região Nordeste resolve patrocinar expedições militares para atacar os "Aimorés". Posteriormente, a cultura do cacau começa a penetrar no sul da Bahia. Buscando ocupar novas terras, os fazendeiros contratam jagunços para expulsarem os índios que viviam na mata.

Maria Hilda Paraíso (1982), porém, com base em referências documentais do século XVII, contata que já naquela época os Pataxó sofriam violentas perseguições dos colonizadores. Segundo esta autora:

As fugas constantes em que viviam [os Pataxó], sofreram violentos ataques desde esta ocasião [século XVII], o que teria provocado redução violenta de sua população e desarticulação social decorrente das imposições e pressões sofridas (PARAÍSO, 1982:105).

Cardoso (2000:54) assinala que:

Foi a partir do século XIX que os contatos entre os brancos e os Pataxó meridionais intensificou-se na região de Porto Seguro. Este contato se deu sob a forma de uma política de integração das áreas das antigas capitanias de Ilhéus, Porto Seguro e Espírito Santo ao mercado de economia nacional.

O príncipe alemão Maximiliano de Wied-Neuwied (MAXIMILIANO, 1989:214-215) esteve em contato com indivíduos da etnia Pataxó em 1816, e em seu livro Viagens ao Brasil descreveu-os da seguinte forma:

Esses selvagens não têm nenhuma aparência extraordinária, não são nem pintados nem desfigurados: alguns são baixos, a maioria é de estatura meã, um tanto delgados, de caras largas e ossudas e feições grosseiras. Uns poucos, somente, traziam, amarrados em volta do pescoço, lenços que lhes deram em ocasiões anteriores; o chefe, que não tinha nada de notável [...] usava uma acarapuça de lã vermelha e calções azuis obtidos algures. Comida era o principal desejo dêles; deram-lhes côcos e um pouco de farinha; abriam aqueles mui destramente, com uma machadinha; arrancando em seguida, da casca dura, com os dentes poderosos, a polpa branca: a avidez com que comiam era notável ${ }^{15}$. [...] Alguns deles tinham muito tino para comerciar. Queriam, sobretudo, facas e machadinhas, sendo que um, entretanto, logo adquiriu um lenço vermelho e o amarrou em volta do pescoço.

[...]

No aspecto externo, os Patachós assemelham-se aos Puris e aos Machacaris, com a diferença de que são mais altos que os primeiros; como os últimos, não desfiguram os rostos, usando os cabelos naturalmente soltos, apenas cortados no pescoço e na testa,

${ }^{15}$ A cena descrita até este ponto é retratada em uma gravura também de autoria do príncipe que se encontra reproduzida nesta monografia na página 101. 
embora alguns rapem toda a cabeça e deixem só um pequeno tufo adiante e outro atrás. Há os que furam o lábio inferior e a orelha, metendo um pequeno pedaço de bambu na abertura. Os homens, à maneira de todas as tribos da costa oriental, trazem as facas penduradas a um cordel amarrado ao pescoço; os rosários que lhes dão, penduram-nos do mesmo modo. A pele tem o tom natural pardo-avermelhado, não sendo pintada. Conservam o curiosíssimo costume de arregaçar o prepúcio com um ramo de cipó, o que dá ao órgão aparência muito singular. [...] As mulheres, tanto como os homens, não se pintam, $e$ andam inteiramente nuas.

Este autor segue em seu livro de viagens, descrevendo detalhadamente vários costumes dos Pataxó e imprimindo inclusive algumas impressões pessoais que teve a cerca desses índios:

os Patachós são, entre todas, os mais desconfiados e reservados; o olhar é sempre frio e carrancudo, sendo muito raro permitirem que os filhos se criem entre os brancos, como as outras tribos o fazem prontamente. Vagueiam pelas matas, e as suas hordas surgem, alternadamente, no Alcobaça, no Prado, em Comechatiba, Trancoso, etc. (Maximiliano, 1989:215).

Não muito tempo depois do encontro com o príncipe alemão, os Pataxó foram sendo expulsos de suas terras tradicionais. Alguns indígenas foram assimilados como mão-de-obra nas fazendas da região; outros se agruparam em novos redutos, em espaços territoriais bem menores. Conforme afirma Sampaio (2005), "tudo indica que, já em meados do século XIX, a maioria da população indígena sobrevivente vivia junto às vilas coloniais costeiras - de Santa Cruz Cabrália a Porto Alegre, atual Mucuri -, para onde fora trazida na tentativa de submetê-la ao trabalho a serviço dos regionais".

Segundo Cardoso (2000:54), "Os primeiros aldeamentos dos Pataxó nesta região [da Costa do Descobrimento] datam de um período anterior ao ano de 1805. Nesta época, os índios que habitavam área próxima ao atual Parque Nacional do Monte Pascoal foram transferidos para a vila do Prado. Nesta área, foram agrupados a outros índios identificados como 'mansos', que ali já tinham sido aldeados".

Em 1861, o governo da província da Bahia, apreensivo com os constantes conflitos entre índios e colonos da região e, também, com a possibilidade de os índios reivindicarem a posse das terras que estavam ocupando, resolveu concentrar compulsoriamente toda a população indígena regional em uma única aldeia, onde hoje é a aldeia de Barra Velha (SAMPAIO, 2005). 
Em Barra Velha foram concentrados não só os Pataxó, mas também indígenas de outras filiações étnicas, como Maxakali, Botocudo, Kamacã, além de remanescentes de ex-aldeamentos Tupi. "Sobre esta muito provável diversidade original, o etnômio Pataxó prevaleceu provavelmente por ter sido destes o maior contingente, além de estar a aldeia situada em território tradicionalmente reconhecido como pataxó" (Idem).

De acordo com Sampaio (2005), até o início do século XX, os índios de Barra Velha viviam sem estabelecer muitos relacionamentos com não-índios, excetuando alguns contatos comerciais intermitentes com a população dos vilarejos locais. $O$ quadro descrito por Rocha Júnior (1987:42), todavia, diz o seguinte:

Instalada a aldeia de Barra Velha, [...] o processo aculturativo foi extremamente rápido, com os índios se adaptando ao sistema de subsistência e pequeno comércio local. Os “caboclos” de Caraívas eram os modelos e também agentes dessa aculturação, diferenciando-se, porém dos Pataxó. Iniciada a aldeia com grupos já pacificados, outros bandos, gradativamente, teriam sido por ela atraídos, pressionados pela crescente expansão, mesmo que lenta, da sociedade regional; nela, ou próximo á ela, buscaram acomodação [...]. Apesar dessa integração intertribal, tais bandos devem ter mantido uma relativa autonomia [...].

Valle (2000) cogita a hipótese de que os Pataxó, no passado, tenham mantido contato com missionários católicos na aldeia de Barra Velha. De acordo com esta autora:

Há relatos da construção de uma igreja em Meio da Mata, lugar próximo de Barra Velha, mas na memória dos índios - e eu indaguei várias pessoas -, no centro da aldeia não chegou a morar nenhum padre, ainda que viessem sempre para visitas. De qualquer forma, o traçado atual dos arruamentos indica um planejamento urbanístico típico dos aldeiamentos missionários (VALLE, 2000:71).

A autora reforça essa sua hipótese ao fazer a seguinte afirmação:

Acredito que os altares nas casas dos líderes, a paixão por festas religiosas, procissões e romarias, também têm a ver com este convívio [com missionários capuchinhos], pois ele se intesificou entre os pataxó da Barra Velha a partir de 1861, época em que eles estiveram entregues à própria sorte, em contato com colonos e aventureiros de toda a espécie (VALLE, 2000:72).

Em 1951 ocorreu um confronto dos Pataxó com os moradores de um povoado vizinho que desencadeou uma violenta reação policial e uma série de perseguições que culminaram na dispersão dos índios pela região (Sampaio, 2005). Segundo Rocha Júnior (1987:42), após esse episódio "os índios se espalharam pela região, 
em pequenos núcleos em simples unidades domésticas, buscando trabalho em fazendas ou novos assentamentos na mata". Mas com o passar do tempo, alguns índios retornaram a Barra Velha, devido á dificuldade de encontrarem condições de subsistência fora desta aldeia.

Valle (2000:88) afirma que: "Ao se reunirem de novo [após as dispersões pela região], muitos [Pataxó] voltaram casados com brancos, negros e mestiços. Esse é o momento da mistura de povos $^{16}$ em Barra Velha. Antes só havia uniões entre membros da mesma tribo". Mais adiante (Ibidem, p.89), a autora acrescenta que: "Os que vieram de 'fora', portanto, juntaram-se aos índios, aos seus valores, ao seu modo de vida, de pensar o mundo".

Em 1961, um decreto presidencial homologou o Parque Nacional do Monte Pascoal (PNMP), que passou a incorporar a totalidade das terras ocupadas pelos índios em Barra Velha. A legislação ambiental proíbe a exploração de recursos naturais em quaisquer condições dentro dos Parques Nacionais (PARNAs), uma vez que esses Parques são considerados Unidades de Conservação de proteção integral. Com isso, os fiscais do IBDF (atual IBAMA), órgão governamental responsável pela gestão do Parque na época, por muitas vezes, chegaram a coibir a iniciativa dos índios em praticar atividades de subsistência como o plantio de roças, a coleta de caranguejos no mangue e a pesca eventual (Rocha Júnior, 1987: 42-43).

De acordo com Sampaio (2005),

[...] os índios foram então compungidos a receber indenizações por suas parcas 'benfeitorias' e deixar sua aldeia [...]. A maioria dos índios resistiu a isto, sendo, porém impedidos de plantar suas roças na área, situação que perdurou por dez anos até que, no início dos anos setenta, o novo órgão indigenista - FUNAI [...] - finalmente implantasse sua assistência e tutela de direitos sobre esses Pataxó. [...].

Foi somente em 1969 que o Governo Federal passou a prestar assistência aos Pataxó, através da instalação de um Posto Indígena (PIN) da FUNAI em Barra Velha. Depois de muitos desentendimentos e conflitos de competência entre FUNAI e IBDF sobre a jurisdição da área sobreposta entre o PNMP e a TI, o órgão indigenista conseguiu assegurar um acordo para que os índios utilizassem parte do território de aproximadamente 210 ha. Isso tudo, porém, não eliminou as dificuldades

\footnotetext{
${ }^{16}$ Grifo do original.
} 
de sobrevivência que o povo Pataxó vivenciava. Conforme descreve Rocha Júnior (1987:46):

\begin{abstract}
A terra, porém, era insuficiente, constituída na maior parte de campos improdutivos, ficando de fora mesmo o famoso mangue; a mata, estreita faixa a oeste, só permitiu a instalação de pequenos lotes familiares, contíguos, dificultando sobremaneira a utilização de técnicas tradicionais, como a coivara; a caça, na área do Parque (cercado com arame farpado) foi terminantemente proibida, e desapareceu fora dessa área, devido aos desmatamentos e instalação de fazendas; mesmo a criação de pequenos animais (porcos, galinhas) se viu prejudicada pela proximidade física entre as roças. Terminada a fertilidade natural de terrenos virgens, a produtividade caiu bastante e a subsistência se tornou difícil - com isso, voltam a crescer as pressões por parte dos índios pela reconquista de todo o Parque.
\end{abstract}

Diante de tantas dificuldades, os índios passam a procurar outras alternativas de subsistência. Ainda nos primeiros anos da década de 1970, a região de Porto Seguro começa a se consagrar como destino turístico. Muitos índios acreditaram que poderiam obter vantagens a partir desse fato. Sampaio (2005) afirma que:

[...] inviabilizados na utilização de suas terras tradicionais, os Pataxó são levados a se engajar como mão-de-obra nas novas atividades econômicas que se implantam na região, sendo também estimulados, a partir dos anos setenta - por pesquisadores, funcionários [da FUNAI] e comerciantes -, a desenvolver sua produção de artesanato, o que se revelaria uma alternativa interessante, capaz de preservar-lhes, em função do fluxo turístico, alguma autonomia econômica.

Segundo Grünewald (2002:209), no início dos anos 70, um funcionário da FUNAI, de nome Leonardo Machado, chefe de posto na época, percebendo a escassez de alternativas de subsistência dos Pataxó de Barra Velha, passou a ensinar indivíduos pertencentes a esse grupo a confeccionar peças de artesanato segundo padrões estilísticos semelhantes aos dos índios Xerente, com quem havia trabalhado anteriormente, e das peças vendidas pela loja Artíndia, da FUNAI. Os Pataxó foram também estimulados por Leonardo a comercializar as peças produzidas. Segundo Carvalho (1977, apud Cardoso, 2000:51), inicialmente os Pataxó encaravam a venda do artesanato como uma atividade secundária e os mais velhos tinham vergonha de ter que comercializa suas peças. Porém, com o tempo, novas formas de artesanato foram sendo incorporadas e criadas conforme a aceitação do público, principalmente dos turistas que começavam a afluir para Porto Seguro.

Em novembro de 1972, a aldeia de Coroa Vermelha começou a ser formada, quando uma família Pataxó se estabeleceu no local onde ocorreu o Descobrimento 
do Brasil. No ano seguinte, várias famílias provenientes da Aldeia de Barra Velha e outros núcleos se mudaram para lá na tentativa de ganhar a vida vendendo e trocando artesanato com alguns poucos hippies que freqüentavam aquela praia. $\mathrm{Em}$ 1974, inaugura-se naquele local o marco do descobrimento, com a instalação inclusive de uma grande cruz de madeira que simboliza a Primeira Missa celebrada no Brasil. A inauguração da rodovia BR-101, e, posteriormente, a abertura de vicinais, aumentou o fluxo de pessoas que se dirigiam a Porto Seguro. Desse momento em diante o turismo começou a se desenvolver na região, num primeiro instante, de maneira bastante tímida, mas, a partir da década de 1980, de forma avassaladora (GRÜNEWALD, 2002:209-210).

Sampaio (1996b:700) relata que inicialmente a ida dos Pataxó para Coroa Vermelha foi apoiada por empresários regionais e também pela prefeitura de Santa Cruz Cabrália, que em 1972 destinou e demarcou informalmente lotes naquele local para os índios, "construindo-Ihes inclusive casas de planta arrendondada e cobertura de piaçava, de modo a corresponder aos estereótipos de indígenas e atender ao público turista". Os empreendedores turísticos e o poder público achavam interessante ter índios caracterizados vendendo artesanato junto ao marco que celebra o Descobrimento do Brasil. Posteriormente, na medida em que Coroa Vermelha foi se valorizando como ponto turístico, esse local foi sendo preterido por interesses do mercado imobiliário. A prefeitura de Cabrália então cedeu vários aforamentos a uma imobiliária - "alguns incidentes em áreas utilizadas pelos índios para criatórios domésticos, hortas etc." (SAMPAIO, 1996b:700) - desencadeando conflitos entre a comunidade indígena e o capital privado pela posse do território, que iriam perdurar por muitos anos até a demarcação da Terra Indígena pela FUNAI no fim da década de 1990 .

Desde a consolidação de Coroa Vermelha como local turístico, a população indígena residente nessa aldeia cresceu significativamente, impulsionada pelo afluxo de muitas famílias oriundas de outros núcleos indígenas da região, principalmente da aldeia de Barra Velha, que tinham a perspectiva de passarem a viver exclusivamente da produção e da comercialização do artesanato com os turistas (GRÜNEWALD, 2002:209-210). Dessa forma, foi se consolidando uma aldeia urbana e comercial. O 
expressivo crescimento demográfico de Coroa Vermelha nas décadas de setenta e oitenta está associado não só ao desenvolvimento do turismo local, mas também às dificuldades vividas pelos índios em outras aldeias e agrupamentos.

Com os rendimentos advindos da venda do artesanato, os índios conseguiam adquirir certos bens de que precisavam e que só poderiam ser obtidos no comércio com os não-indígenas, entretanto, a atividade nunca se mostrou, por si só, capaz de suprir todas as necessidades da comunidade, até mesmo porque a sazonalidade dos fluxos turísticos é grande, fazendo oscilar os ganhos com a venda do artesanato, e são poucos os índios que têm a prática de poupar dinheiro para se manterem na baixa temporada do turismo.

Para que pudesse garantir suas condições mínimas de subsistência, a população indígena necessitava explorar também outras atividades. Por esse motivo os Pataxó ocuparam uma faixa de floresta próxima à praia, de onde retiraram sementes e madeira para utilizar como matéria-prima para a confecção do artesanato. Na época, parte da madeira retirada era comercializada com madeireiras, fato que suscitou muita polêmica dentro da própria comunidade indígena. No local desmatado, os índios passaram a praticar a agricultura e pretendiam também introduzir a criação de animais para sua alimentação e o cultivo de plantas medicinais. (GRÜNEWALD, 2002:210-211).

Em 1998, um grupo de cerca 30 Pataxós moradores de Coroa Vermelha tomou a iniciativa de ocupar uma área de Mata Atlântica, batizada como "Reserva da Jaqueira", se comprometendo a assegurar a conservação ambiental desse espaço e utilizá-lo para a vivencia de práticas indígenas tradicionais e para a exploração do ecoturismo. Segundo a versão dos índios, a área da Reserva "pertencia ao grupo Empreendimento Góes Cohabita, que na época [da ocupação dos índios] planejava a construção de loteamentos no local, abrindo estradas no meio da Mata Atlântica e extraindo recursos como areia, madeira e barro" (ASPECTUR, 2007:12). Esse fato desencadeou a reação dos Pataxó, que, por conseqüência, passaram a ocupar toda a área de mata existente nesse território. 
Na página eletrônica de divulgação da Reserva da Jaqueira ${ }^{17}$, os próprios índios contam um pouco da história da retomada desta área:

No mesmo ano de 1997 ficamos sabendo que uma empresa iria lotear e retirar os recursos naturais de parte de Gleba $B$, ou seja, iria retirar as árvores, plantas e animais que ali existem. [...] Com ajuda de parentes de outras aldeias retomamos o local de forma pacífica.

No dia $1^{\circ}$ de agosto de 1998, num sábado, saímos de Coroa Vermelha em um grupo de 30 índios, entre jovens e adultos, para fazer um passeio na mata. Lá revivemos como os nossos antepassados viviam no seu verdadeiro lugar e percebemos a importância da floresta para fortalecer o nosso espírito e a nossa cultura. Quando voltamos, nos reunimos, conversamos e percebemos que todos tínhamos o mesmo objetivo: vivenciar e demonstrar a beleza da nossa cultura e preservar o meio ambiente.

Atualmente Terra Indígena de Coroa Vermelha está regularizada em uma área total de 1.493 ha dividida em duas partes: "Gleba A" e "Gleba B". A primeira consiste em uma porção territorial de 77 ha localizada á beira da praia, onde há uma aldeia urbana e onde a cruz que simboliza a Primeira Missa rezada no Brasil está instalada. A segunda dista $6 \mathrm{~km}$ da primeira, com seus $1.416 \mathrm{ha}$, subdivide-se na Reserva da Jaqueira (827 ha), destinada à conservação ambiental e exploração do ecoturismo; e mais outra área adjacente, utilizada para a agricultura e para a extração de matériaprima para o artesanato, com aproximadamente 589 ha.

\section{2 - MUDANÇAS CULTURAIS E RECONSTRUÇÃO DAS TRADIÇÕES}

Como a região que os Pataxó sempre habitaram foi uma das pioneiras no processo de ocupação pelos colonizadores do Brasil, ainda que esse grupo indígena tenha conseguido assegurar por muito tempo a sua autonomia, não mantendo relações muito regulares com a sociedade envolvente, os contatos com as frentes de expansão da sociedade nacional atingiram muito mais precocemente estes índios do que os que habitavam outras regiões do país. Tais contatos, inegavelmente, produziram alterações significativas no modo de vida tribal ao longo do tempo.

Os Pataxó, assim como a grande maioria dos povos indígena da região Nordeste, não tardaram a serem submetidos a uma série de compulsões que culminaram na transformação radical de seu modo de vida, na descaracterização de sua cultura tradicional e na desestruturação do sistema econômico e político tribal, processo o qual Darcy Ribeiro denominou como "transfiguração étnica".

\footnotetext{
${ }^{17}$ http://www.rabarsa.com/pataxo/inicial.html
} 
A transfiguração étnica consiste em uma série de fatores causais (compulsões ecológicas, bióticas, tecnológico-culturais, sócio-econômicas e ideológicas) que podem agir simultaneamente ou em etapas sucessivas.

As formas de compulsões ou coerções as quais os indígenas estiveram submetidos ao longo da história foram desencadeadas principalmente por ações e intervenções das frentes de expansão econômica da sociedade nacional, dos missionários religiosos e até mesmo do órgão oficial de proteção aos índios.

Como já foi dito anteriormente, até o início do século XIX, os Pataxó e outros grupos indígenas pertencentes ao tronco lingüístico Macro-Jê continuavam vivendo dispersos pelas matas da região sul da Bahia, organizados em pequenos bandos, sobrevivendo da caça e da coleta e não sofrendo compulsões muito agudas como as que sofreriam posteriormente; porém, alguns desses índios já mantinham contatos com indivíduos da população regional, com quem comercializavam alguns bens que produziam. Daí provavelmente os índios adquiriram as primeiras influências culturais da sociedade envolvente. Pouco mais tarde, já em meados do século XIX, a atração desses índios para aldeamentos e núcleos próximos aos povoados da Costa do Descobrimento, ocasionou um contato já mais regular com a população nacional, que certamente trouxe novas influências para os povos indígenas.

A pressão exercida por agentes da sociedade nacional que tinham interesses em suas terras, como fazendeiros e pecuaristas, fez com que esses índios aos poucos fossem cedendo ao poderio dos "civilizados" e sendo atraídos por estes ao comércio (ROCHA JÚNIOR, 1987:43).

O confinamento forçado dos índios em Barra Velha, que ocorreu a partir 1861, certamente contribui muito para que esses índios fossem gradativamente adotando novos padrões culturais adaptados às novas condições de existência. Sobre essa questão, Rocha Júnior faz a seguinte consideração:

Constituída uma aldeia estável, segue-se uma readequação de vários níveis da cultura indígena, especialmente o econômico. A agricultura se torna mais importante e os pataxó aprendem - se já não o sabiam - a cultivar a mandioca e a produzir farinha. A adoção de uma nova tecnologia, a sedentarização mais prolongada e num ambiente distinto da floresta e a proximidade de núcleos civilizados (e de índios já intensamente aculturados) foram sem dúvida os principais fatores a alterar a cultura pataxó e a coloca-los num novo nível de integração sócio-cultural (ROCHA JÚNIOR, 1987:44). 
Após o agrupamento inicial desses índios em Barra Velha, ainda ocorreu uma série de diásporas que fizeram com que eles se dispersassem pela região, se engajando muitas vezes na condição de empregados de fazendas. Esse fenômeno sem dúvida ocasionou uma convivência maior com a sociedade não-indígena e, conseqüentemente, a adoção de muitos dos seus padrões culturais. Os casamentos interétnicos passaram a ser comuns, decorrendo daí um grau acentuado de miscigenação. A cada nova reconcentração do grupo indígena na aldeia, se faziam notar várias transformações culturais que haviam se sucedido.

É inegável que as condições as quais os Pataxó estiveram submetidos ao longo de séculos de contato com os não-indígenas fizeram com que muitos dos usos e costumes desse grupo étnico sofressem inúmeras transformações, cuja evidência não se pode disfarçar. A língua original dos Pataxó foi perdida; o padrão alimentar desses índios se alterou; a sua crença religiosa sofreu grande influência do cristianismo, mais especificamente do catolicismo; os membros do grupo passaram a usar roupas ocidentais, e assim por diante...

Pelo fato de os grupos indígenas do Nordeste brasileiro - incluindo os Pataxó terem sofrido de forma intensa e prolongada as compulsões inerentes ao processo de transfiguração étnica, hoje o seu padrão cultural se encontra bastante descaracterizado em relação ao que era originalmente. Por esse motivo, a identidade indígena desses povos já foi muitas vezes contestada ou colocada em descrença pelas populações com quem convivem.

Leme e Neves (2005) atestam a discriminação sofrida pelos Pataxó ao afirmarem que, "os indígenas de Porto Seguro sofrem também dificuldades de aceitação pela sociedade local. Persistem acusações de falta de 'autenticidade' não só por parte da sociedade local, como muitas vezes por parte dos turistas".

Até mesmo alguns acadêmicos consagrados e o próprio Estado nacional chegaram a reforçar a descrença quanto à legitimidade do caráter indígena de povos do Nordeste. Segundo Arruti (1995), a etnografia brasileira dos últimos dois séculos muitas vezes se reporta aos índios do Nordeste, de forma genérica, como grupos que teriam sido "exterminados fisicamente ou assimilados completamente à cultura e 
à sociedade regional, passando a compor o tipo humano e cultural do caboclo ou sertanejo". O autor ainda relata o seguinte:

A partir da primeira metade do século XIX os grupos indígenas do Nordeste brasileiro passam a ser tratados, tanto pelo Estado quanto pelos pensadores sociais, como entidades extintas, tornando-se, nas primeiras décadas do século $\mathrm{XX}$, objeto de interesse acadêmico apenas quando da reunião e comentário de textos e gravuras de missionários e viajantes dos séculos XVI, XVII e XVIII, onde eram procurados elementos que permitissem reconstruir antigas repartições geográficas, famílias lingüísticas, fragmentos de vocabulários ou ainda avaliar a “contribuição” destes grupos para o avanço colonial (ARRUTI, 2005:01-02).

As dúvidas sobre a efetividade de algumas populações indígenas do Nordeste chegaram a ser levantadas inclusive por célebres indigenistas brasileiros. Tendo estudado esses índios na década de 1950, Eduardo Galvão (1979 [1957]:225-226) descreve o seguinte a respeito deles: "A maior parte vive integrada no meio regional, registrando-se considerável mesclagem e perda dos elementos tradicionais, inclusive a língua". O mesmo autor chega a se referir aos Pataxó como "índios mestiçados". Darcy Ribeiro (1986) chega a ponto de incluir os Pataxó e outros grupos étnicos dentro de uma listagem de povos indígenas já extintos na década de 1950.

Para Pacheco de Oliveira, a insegurança sobre a legitimidade do caráter étnico diferenciado de grupos indígenas do Nordeste pairava também sobre o órgão de proteção oficial (SPI, depois FUNAI). Diz este autor o seguinte:

O órgão indigenista [...] sempre manifestou seu incômodo e hesitação em atuar junto aos “índios do nordeste”, justamente por seu alto grau de incorporação na economia e na sociedade regionais. $O$ padrão habitual de ação indigenista ocorria em situações de fronteira em expansão, com povos indígenas que mantinham sob seu controle amplos espaços territoriais (ou, inversamente, ameaçavam o controle das frentes sobre estes) e que possuíam uma cultura manifestamente diferente daquela dos não-índios. [...].

No Nordeste, contudo, os “índios” eram sertanejos pobres e sem acesso à terra, bem como desprovidos de forte contrastividade cultural. Em uma área de colonização antiga, com as formas econômicas e a malha fundiária definidas há mais de dois séculos, o órgão indigenista atuava apenas de maneira esporádica, respondendo tão-somente às demandas mais incisivas que recebia. Mesmo nessas poucas e pontuais intervenções, o órgão indigenista tinha que justificar para si mesmo e para os poderes estaduais que o objeto de sua atuação era efetivamente composto por “índios”, e não por meros “remanescentes”. (Oliveira, 1998: 52).

Nas últimas décadas, observa-se o engajamento dos Pataxó no sentido de reconstruir e fazer legitimar uma identidade étnica diferenciada da sociedade envolvente por meio da valorização de suas práticas culturais próprias e a revisão do seu idioma que estava praticamente abandonado. Além disso, esses índios 
procuraram incrementar suas tradições a partir de novos elementos culturais e sinais diacríticos que vão sendo criados ou incorporados através do contato com diversos segmentos sociais com quem interagem continuamente, inclusive com índios de outras etnias.

A língua que os Pataxó atuais se utilizam correntemente para se comunicar entre si e com os não-índios é o português. No entanto, cresce cada vez mais entre os indígenas o uso do Patxohã, idioma que vem sendo construído e adotado para a comunicação interna do grupo. Inclusive, dos índios que participam do projeto turístico da Reserva da Jaqueira, são muitos os que sabem falar - como maior ou menor desenvoltura - esse idioma. Nas placas de sinalização turística da Reseva estão impressas frases escritas em Patxohã.

Conforme Grünewald (2001:83):

O “idioma Pataxó” que os índios apresentam atualmente é composto de uma estrutura gramatical portuguesa e léxico maxakali, tupi e algumas palavras de origem incerta. Não há ocorrência de palavras de uma língua falada pelos antigos Pataxó, tais como as compiladas, por exemplo, por Wied-Neuwied (1820) no primeiro decênio do século XIX. Além disso, os Pataxó não se valem do vocabulário tradicional que compõe a cartilha Bahetá [da Comissão Pró-índio], e os índios usam palavras diferentes para referir-se a uma mesma coisa, não por sofisticação lingüística, mas por pura confusão.

A necessidade de atrair a atenção dos turistas objetivando a venda do artesanato e a luta pelo território e pelo reconhecimento do Estado na prestação assistência, certamente são fatores que têm motivado o esforço dos Pataxó em reforçar a unidade do grupo e ressaltar publicamente a sua especificidade étnica. São perceptíveis as estratégias de delimitar a fronteira étnica do grupo indígena em relação à população que habita o entorno das aldeias e também em relação aos turistas.

Nos anos mais recentes, nota-se uma intensificação da incorporação de sinais diacríticos e artefatos que teriam a função de atestar a "autenticidade" do caráter de "indianidade" do grupo perante os olhos das populações com quem mantém contato (turistas, comunidade local, outros grupos indígenas, etc.). Um exemplo marcante dessa construção social é o que descrevem Giménez e Coelho (2005:162):

Segundo informações colhidas na Barra Velha e aldeias vizinhas, em 1985 a pintura corporal era considerada inaceitável para o padrão de beleza nada ostensivo do grupo. [...] 
A partir dos preparativos para as comemorações no ano 2000, difundiu-se na aldeia de Coroa Vermelha, um tipo de pintura nos braços e rosto, de tipo linear, reto e angular, com retas paralelas longitudinais nas pernas, sem significado social ou religioso aparente. Não sabemos qual foi o elemento externo que introduziu essas pinturas, pois não estão relacionadas com a imitação de costumes de outra etnia indígena. Acreditamos que ocorreram como resposta a uma necessidade crescente de auto-identificação, como nação indígena, que de um modo geral estava sendo cobrado, durante os preparativos para as comemorações dos 500 anos [do Descobrimento].

Desligados da estrutura de linguagem simbólica, as pinturas adquirem desse modo, uma nova conotação que incentiva a assumir a indianidade.

O príncipe alemão Maximiliano Wied-Neuwied, quando esteve em contato com índios Pataxó no início do século XIX, observou que estes não ostentavam pinturas corporais (MAXIMILIANO, 1989:214). Paraíso (1982), porém, tomando como referência estudos das primeiras décadas do século XX, feitos por Nimuendajú e Loukotka, afirma que os Pataxó contatados nesta época:

Pintavam-se seguindo padrões semelhantes aos dos Kamakã: traços geométricos nas cores vermelha e negra. As tintas eram fabricadas com frutos e resinas de árvores e óleos vegetais misturados com óleos animais (PARAÍsO, 1982:108).

Contudo, a pintura que os Pataxó apresentam nos dias atuais não se assemelha no seu padrão estético com a da descrição acima citada; nem os materiais utilizados são os mesmos mencionados. Se os Pataxó no começo do século passado fizeram uso de pinturas corporais, as pinturas que seus descendentes apresentam hoje não são fruto de uma continuidade histórica do grupo, mas sim, criações recentes e adaptações de empréstimos culturais de outros povos indígenas.

Segundo a antropóloga Leila Sotto Maior ${ }^{18}$, em 2001, lideranças Pataxó promoveram um seminário que teve como resultado a definição de padrões de grafismo das pinturas corporais deste grupo indígena. Para cada padrão foi atribuído um significado.

Em uma reportagem publicada na Folha de São Paulo em 07/09/06, encontramos a seguinte explicação para o significado das pinturas que os índios da Reserva da Jaqueira levam em seus rostos: "As pinturas representam o estado civil e o humor de cada um deles. Quando casado, estampam-se em sua face duas linhas paralelas fechadas. Se for solteiro, uma dessas linhas se abre, formando um ' $V$ "'19.

\footnotetext{
${ }^{18}$ Informação fornecida em entrevista realizada no dia 21/12/2006, na sede da FUNAI em Brasília.

${ }^{19}$ Fonte: FOLHA DE SÃO PAULO. Tribo Pataxó Apresenta Seus Costumes em Reserva. Turismo. p. F1. 07/09/2006.
} 
No site da Secretaria Municipal de Turismo de Porto Seguro há um verbete explicativo sobre a pintura corporal dos Pataxó. Esse verbete - que provavelmente foi escrito por um índio - já que faz referência ao grupo Pataxó na primeira pessoa do plural - diz o seguinte:

A pintura corporal é um bem cultural de grande valor para nós Pataxó. Ela representa parte de nossa história, sentimentos do cotidiano e os bens sagrados. Usamos a pintura corporal em festas tradicionais na Aldeia como em ritos de casamento, nascimento, comemorações, dança, luta, sedução, luto, proteção, etc. Temos pintura para o rosto, braço, costas e até mesmo para as pernas. Usamos pinturas específicas para homens e mulheres casados e solteiros. As pinturas têm diversidade de tamanho e significados. ${ }^{20}$

Já nos anos 1970, por ocasião do Dia do Índio (19 de abril) e das comemorações do Descobrimento do Brasil, os Pataxó eram contratados para fazer performances caracterizados enquanto índios de acordo com os estereótipos imaginados pela sociedade nacional. Daí já decorreu a adoção de alguns elementos estéticos pelo grupo. Porém, a partir das comemorações dos 500 anos do descobrimento do Brasil, evento promovido pelo Governo Federal em Coroa Vermelha no ano 2000 e que mobilizou a atenção da imprensa em escala nacional e internacional, o movimento pela afirmação identitária dos Pataxó, inclusive no que tange á adoção de elementos culturais simbólicos, seguramente se intensificou. Com referência a isso Giménez e Coelho (2005:165), asseveram o seguinte:

Diante da expectativa da festa dos $\mathbf{5 0 0}$ anos do Brasil, a atualização de suas tradições era muito importante para, através do encenar de uma autenticidade, alcançar a legitimidade como índios do descobrimento. Se os pataxó não são os tais, precisavam aparentar ser os índios nativos. Há uma cobrança interna pelos líderes do grupo étnico, para que seus membros desempenhem essa ação, que parece ter surgido a partir das cobranças de indianidade demandada pelo púbico e assim eles devem se construir como Índios do Descobrimento, visando tanto à platéia turística compradora de suas peças artesanais $\mathrm{e}$ os órgãos oficiais, que podem legitimá-los como donos da terra, quanto a si mesmos. A referência ao passado aparece ligada à identidade e ao discurso político em construção entre os pataxó.

É bem provável que a convivência estreita com índios de outras etnias em eventos indígenas pelo Brasil afora tenha estimulado os Pataxó nessa busca da afirmação étnica através da adoção de certos sinais diacríticos tal como vemos hoje. A possibilidade, por exemplo, de que certos padrões de pintura corporal adotados pelos Pataxó nas últimas décadas tenham sido inspirados na pintura tradicional dos guerreiros Kayapó e dos índios do Parque do Xingu nos parece bem plausível.

\footnotetext{
${ }^{20}$ Fonte: <http://www.portosegurotur.com.br/porto_lazer-jaqueira2-3.htm>.
} 
Cardoso (2000) também identifica a estratégia dos Pataxó em ressaltar a sua diferença étnica em relação ao restante da população nacional por meio da adoção de sinais diacríticos que os façam serem percebidos conforme o estereótipo que a sociedade brasileira em geral construiu a respeito das populações indígenas. Segundo esta autora:

Os Pataxó têm perfeito conhecimento da representação nacional do índio. Eles sofrem com esta situação e, em parte, tentam reproduzi-la para que, assim, possam ser reconhecidos como índios e, deste modo, conseguir formas de sobreviver. Diante da cobrança para que se afirmem enquanto índios, eles investem tempo e esforços para elaborar um quadro onde constem elementos que os identifiquem enquanto tal - como usar cocares, colares, pinturas corporais, arcos e flechas - em suas representações para os turistas, seja na área da Reserva, seja nas apresentações nos centros urbanos. Nestas ocasiões, eles se vestem com saias e soutiens de palha, pintam seus rostos e corpos com urucum ou batom, cantam e dançam de forma tradicional (CARDOSO, 2000:104).

\section{As tradições Pataxó são efetivadas conforme o que aponta Grünewald (2001:10):}

[...] o termo tradição surge no discurso Pataxó em duas acepções e, em ambas, possui o significado de uma cultura própria ao grupo étnico: mesmo que sua formação histórica inclua elementos externos, a partir de sua incorporação eles passam a ser próprios do grupo, ou seja, de sua tradição. Além disso, mesmo criadas no presente, essas tradições devem se referir a conjunturas culturais (danças, língua, peças artesanais) ou a narrativas históricas (descobrimento do Brasil), a fim de tornar legítimo seu caráter tradicional, de cultura histórica. São inevitavelmente, portanto, tradições em mudança. ${ }^{21}$

Embora perceba uma tentativa de (re)construção social das tradições desse grupo étnico, este autor acredita que esse aspecto não compromete a autenticidade da cultura que é exibida por ele na arena turística, ao afirmar que:

A geração de tradições em fluxos globalizados de cultura não pode ser vista por sua inautenticidade, uma vez que são construções sociais legítimas que posicionam os atores e sua fala no mundo (pós) moderno (GRÜNEWALD, 2001:08).

Desconsiderando a possibilidade de a experiência turística promovida pelos

Pataxó se tratar de um simulacro, o mesmo autor expressa a seguinte opinião:

[...] pensar que existem experiências turísticas inautênticas é não perceber a dinâmica de uma sociedade em termos gerativos, isto é, ignorar que, ao se defrontar com a experiência do turismo, as comunidades e suas culturas localizadas podem se transformar a partir da gênese de novos padrões e permanecer autênticas mesmo através da mudança. (GRÜNEWALD, 2001: 34).

Rocha Júnior (1987), por sua vez, entende que, na tentativa de se enquadrarem nos estereótipos indígenas imaginados pela sociedade ocidental e, assim, agradar os turistas, "os Pataxó se travestem de 'índios', usando as tangas, cocares,

\footnotetext{
${ }^{21}$ Os grifos são do autor.
} 
braçadeiras e colares vistosos de penas que fazem para vender, principalmente na Coroa Vermelha" (ROCHA JÚNIOR, 1987:47), e ainda afirma o seguinte:

Na reserva ${ }^{22}$ ou fora dela, vestem-se como os camponeses da região, mas no comércio de artesanato, ou quando é necessário enfatizar sua identidade (falar com autoridades, participar de atos públicos), transformam-se eles nas imagens dos índios da Primeira Missa, conforme as iconografias mais difundidas em nossa sociedade (ROCHA JÚNIOR, 1987:47).

Deste modo, este último autor parece concluir que a adoção de certos elementos em função das apresentações turísticas afetou a autenticidade da cultura Pataxó. Seguindo sempre essa linha de pensamento, ele coloca o seguinte:

O turismo impactou a identidade étnica dos pataxó, dando-lhes, por um lado, elementos para contrapor à contestação dos regionais, que os vêem como meros "caboclos", mas, por outro lado, realçando sinais diacríticos que não lhe são, talvez, próprios, mas do imaginário brasileiro (ROCHA JÚNIOR, 1987: 46).

Na opinião de Grünewald (2001:59), com a qual estamos de acordo, "o fato de um índio ser turístico e vender-se na arena turística não caracteriza falta de autenticidade [...]. Os Pataxó não são índios só para o turismo, mas nessa arena se fazem e se moldam conforme as expectativas que eles mesmos se impõem".

Grünewald reconhece que há casos em que os turistas se frustram um pouco ao se deparar com índios como os Pataxó, com uma cultura bastante modificada em relação ao estágio anterior ao contato, pois esses turistas têm inicialmente a expectativa de se depararem com índios com uma cultura que eles considerariam "autêntica" por estar pouco afetada pela influência da sociedade nacional em seus costumes. Entretanto, para este autor, o fato de que muitos elementos apresentados pelos Pataxó na arena do turismo serem criações sociais recentes ou mesmo adaptações feitas a partir do contato com elementos culturais de outros grupos, não compromete a autenticidade da experiência turística.

Mesmo na quebra das expectativas quanto à autenticidade das construções culturais locais, isso não tira a autenticidade de sua cultura, uma vez que ela foi gerada em um contexto que, embora não considerado pelos turistas, é socialmente legítimo (GRÜNEWALD, 2001: 36).

Acontece que o turista, de modo geral, é imbuído de uma visão arraigada no senso comum de que as culturas indígenas "autênticas" são aquelas que permanecem "intocadas" pelo processo de "aculturação", enquanto as culturas que

\footnotetext{
${ }^{22}$ Ao utilizar o termo “reserva”, o autor está se referindo ao território indígena de maneira geral.
} 
sofreram influências de elementos exógenos seriam "inautênticas" ou "impuras". A representação mais comumente proferida a respeito dos índios é, segundo Oliveira (2000:23), "a de um indivíduo morador da selva, detentor das tecnologias mais rudimentares e das instituições mais primitivas, pouco distanciado, portanto, da natureza". Para este autor, o que ajuda a fixar tal representação no imaginário das pessoas comuns é a sua veiculação através de manifestações literárias e artísticas, pela ideologia sertanista e pela própria política indigenista atualmente vigente no país.

Oliveira (2000:24) entende que todas as sociedades sofrem transformações culturais advindas dos contatos com grupos externos e nenhuma delas é absolutamente refratária aos fluxos e correntes culturais, e, sendo assim, ele sustenta o seguinte posicionamento:

[...] Para serem legítimos componentes de uma cultura, tais costumes e crenças não precisam ser exclusivos daquela sociedade, freqüentemente sendo compartilhados com outras populações (indígenas ou não). Tais elementos culturais também não são necessariamente antigos ou ancestrais, a adaptação de suas pautas culturais ao mundo moderno e globalizado constituindo-se fato corriqueiro.

A incorporação de rituais, crenças e práticas exógenas não necessariamente significa que aquela cultura já não seria "autenticamente indígena” ou pertencente a "índios aculturados" (no sentido pejorativo de ex-índios ou falsos índios). Operadores externos podem ser ressemantizados e, assim virem a ser fundamentais para a preservação ou adaptação de uma organização social e de um modo de vida indígena (OLIVEIRA, 2000: 24).

Diante da argumentação acima exposta, reconhecemos que as transformações ocorridas na cultura Pataxó em função das representações que fazem para os turistas não comprometem a sua autenticidade, mas antes, a fortalece. Ao analisar o caso Pataxó, Grünewald (2001:29) observa que os fluxos culturais não se dão de forma unilinear; no contato entre os diferentes elementos (indígenas e turistas), estes se influenciam mutuamente. Deste modo, no entendimento do autor, os índios em questão não estariam sendo meros elementos passivos de um processo de aculturação, e sim, "agentes de sua própria formação cultural" (GRÜNEWALD, 2001:21).

Este autor vai ainda mais além ao afirmar que as construções culturais geradas pelos Pataxó são espontâneas e na maioria das vezes não provém da pura assimilação de elementos culturais característicos das populações com quem 
mantêm contato ou impostos pelo processo de globalização. Tais tradições, na verdade,

[...] seguem majoritariamente um contrafluxo, ou seja, da periferia para o centro, e não são repartidas entre os membros dos grupos (pessoas engajadas em fazer sua própria síntese) de forma monolítica, mas caracterizam exemplos de vitalidade cultural que contradizem não apenas o esquema centro-periferia como também a existência de fluxos dentro de cada um desses pólos e até mesmo de localidades, nas quais a cultura deve ser pensada como "intrinsecamente de origem mista, antes que historicamente pura e homogênea” (GRÜNEWALD, 2001:29).

Seguindo praticamente a mesma linha de raciocínio que Grünewald, Leme e Neves (2005), se referindo ao projeto da Reserva da Jaqueira, atestam a autenticidade do caráter cultural do turismo ali promovido. De acordo com esses autores:

[...] o Projeto Jaqueira tem seu sucesso enquanto turismo étnico ou cultural pelo caráter de experiência entre culturas que promove e também por ter como produto o autêntico tão procurado pelos turistas. Autêntico, pois o projeto nasce dos pataxós e pelos pataxós. Não é uma identidade inventada para o turismo, sugerida por agentes externos, mas uma releitura do que é ser um pataxó atualmente, onde o autêntico é a vontade de sobreviver enquanto etnia. E essa vontade de sobreviver é que é vendida justamente para que essa sobrevivência se torne efetiva, através da renda gerada pelo turismo (LEME e NEVES 2005).

O artesanato é o elemento mais representativo que compõe o patrimônio cultural material dos Pataxó atuais e, ao mesmo tempo, é a principal fonte de renda daqueles índios que residem em Coroa Vermelha. Nas formas, nos detalhes e nas pinturas das peças artesanais produzidas por eles estão cristalizados os sinais diacríticos incorporados a partir do contato com outros segmentos e grupos sociais.

Segundo Rocha Júnior (1987:46), o artesanato que os Pataxó comerciam atualmente "é uma criação recente e pouco tem a ver, aparentemente, com os artefatos tradicionais do grupo". Este autor pondera que, nos anos iniciais da década de 1970, antes do boom turístico pelo qual passou Porto Seguro, os Pataxó tinham uma pequena produção artesanal, cujo principal produto era os colares feitos com sementes de "mata-pasto" ainda pouco elaborados. Tal produção era vendida nas festas e em pequenas lojas da cidade. Desde então, teriam sido acrescentados a esse repertório muitos outros itens, que não necessariamente têm uma utilidade prática, a não ser a sua função decorativa enquanto "lembrança dos índios": trata-se de "arco-e-flechas, lanças, bordunas, tangas, brajaú (pequena aljava), casquetes e 
cocares, braçadeiras, bolsas, cortinas, colares de diversos feitios, esculturas em madeira, cestaria, etc." (Idem).

Um relatório do Programa de Regionalização do Turismo no Brasil, do Ministério do Turismo $^{23}$, identifica o artesanato Pataxó como "expressão autêntica das chamadas 'artes do quarto mundo', ou seja, objetos inventados para consumo externo (turistas) e que remetem, ao mesmo tempo, às etnicidades/identidades emergentes ou em mudança. Constitui-se, simultaneamente, de artes étnicas e turísticas que se adaptam às exigências dos consumidores. Mas há nuances entre a arte que é mais definidora de sua tradição (objetos de uso pessoal), e os produtos feitos meramente para venda" (BRASIL, 2006:50-51).

Todavia, a incorporação de novos elementos estéticos ao artesanato indígena não estaria comprometendo sua autenticidade, uma vez que "a mercantilização da cultura não necessariamente destrói o significado dos 'produtos culturais'. Estes, ao se orientarem para o turista, adquirem novos significados para os seus produtores, porque eles podem se tornar uma marca diacrítica da identidade étnica ou cultural, isto é, um veículo de auto-representação da etnia, do grupo, da comunidade diante do público externo" (BRASIL, 2006:51).

As apresentações que os Pataxó fazem de sua própria cultura para os turistas compõem uma espécie de turismo étnico planejado. Procura-se expor ao turista os sinais diacríticos representativos das "tradições" do grupo. Tradições estas, que foram construídas recentemente com o intuito de delimitar uma fronteira étnica que demarque claramente as diferenças entre os Pataxó e a população envolvente, fortalecendo assim a sua identidade e, conseqüentemente, valorizando a autoestima coletiva e o orgulho de ser índio. Esse afloramento do orgulho de ser Pataxó se mostra uma forma de resistência desses índios - cuja "indianidade" muitas vezes é posta em dúvida pela população com quem mantém contato - à dominação cultural preterida pelo processo de globalização homogeneizante. Neste sentido, temos aí um exemplo que nos leva a concordar com o a seguinte afirmação feita por Gonçalves (2004:19):

\footnotetext{
23 BRASIL, Ministério do Turismo. Programa de Regionalização do Turismo - Roteiros do Brasil: Sustentabilidade Sociocultural - Princípio Fundamental. Brasília, 2006.
} 
Os povos indígenas com sua cultura e seus territórios tentam resistir à extinção não só física, mas também cultural... Até porque a vida é mais que biológica: é um determinado modo de ser, pensar, sentir e agir. Cada vez mais, os povos indígenas afirmam a sua singularidade, a sua diferença, enfim, a sua cultura. Há, portanto, uma existência que poderíamos chamar de objetiva, inspirando o movimento dos indígenas e essa objetividade, sabemos, deriva exatamente de sua afirmação como sujeitos de sua própria história, da sua singularidade.

\section{3 - CONDIÇÕES DE VIDA ATUAIS}

$\mathrm{Na}$ aldeia de Coroa Vermelha, local de residência dos índios que operam o ecoturismo na Reserva da Jaqueira, a venda do artesanato é a principal atividade econômica e a fonte de renda mais significativa para a grande maioria dos moradores. Ocorre, no entanto, a exploração de outras atividades que concorrem para a subsistência do grupo.

Segundo um levantamento feito por Espírito Santo em $1998^{24}$, na gleba B de Coroa Vermelha, área reservada para as roças, algumas poucas famílias indígenas praticavam a agricultura, plantando mandioca, feijão, milho, batata-doce, abóbora, melancia, dentre outros gêneros. Os alimentos plantados serviam para o consumo da própria família; quando havia excedente, este era comercializado no interior da própria aldeia. Na gleba $\mathrm{A}$, nos quintais das casas plantava-se também para o consumo próprio das famílias itens como coco, laranja, limão, mamão, manga, pimenta, banana, cana-de-açúcar, plantas medicinais, etc. Foi detectada também a criação de aves, como galinhas e patos.

$\mathrm{Na}$ Gleba B, onde se pratica a agricultura, as terras são divididas entre as famílias indígenas. Cada uma planta em um pequeno pedaço, que pode ser um pouco maior ou menor conforme o tamanho da família. Técnicos da FUNAI acreditam que cerca de 110 famílias fazem uso dessa área para a agricultura, sendo que 85 famílias moram no local.

Alguns índios são proprietários de barracas instaladas na praia de Coroa Vermelha, dentro da terra indígena (Gleba A), onde se vende principalmente artesanato, mas existem barracas que funcionam também como bares. É comum saber de casos de índios que arrendam suas barracas para os não-indígenas, obtendo assim a renda proveniente do aluguel.

\footnotetext{
${ }^{24}$ ESPÍRITO SANTO, Marco Antônio do. Diagnóstico Socioeconômico da comunidade Pataxó da Coroa Vermelha. FUNAI, Brasília, 1998.
} 
Há ainda aqueles índios que praticam a pesca, a mariscagem e o extrativismo vegetal, além de existir um pequeno número deles que conseguem se empregar como assalariados na economia local. No que diz respeito a esse engajamento dos índios como mão-de-obra no mercado local, Sampaio afirma o seguinte:

[...] Embora essa prática seja facilitada pela inserção da aldeia em um meio urbano, ela é percebida pelos índios como desfavorável e indesejável, tanto por fugir às suas tradições, quanto em função de que sua predominante falta de especialização não lhes permite ingresso senão nos extratos inferiores do setor de serviços. Ademais, sua demanda por trabalho ocorre predominantemente nos períodos de "baixa estação", desfavoráveis ao comércio do artesanato, quando, pelas mesmas razões de refluxo do mercado turístico, a oferta de serviços em Porto Seguro e Santa Cruz Cabrália está também deprimida; daí o engajamento pataxó neste mercado se fazer sempre, de fato, em condições muito desfavoráveis de remuneração e sem amparo das regulamentações trabalhistas. [...] (SAMPAIO, 1996: 45).

A venda do artesanato oscila bastante conforme a época do ano, já que depende muito da presença de turistas, e sabe-se que o fluxo turístico naquela região é sazonal. A respeito dessa situação, Macedo (1992:43) descreve o seguinte: "No verão, com o grande fluxo de turistas para a região, a atividade ainda lhes permite sobreviver razoavelmente, mas no inverno mal dá para comer". Sampaio (1996:45) diz que “os meses da 'baixa estação' - de março a junho e de agosto a novembro correspondem, quase sempre, a períodos de penúria da comunidade, quando as famílias que não conseguiram amealhar alguma poupança durante o 'verão' realmente passam por dificuldades". Entre agosto e novembro, as condições de vida da comunidade são ainda mais duras, pois esse é um período de fortes chuvas e enchentes, que inviabilizam a consecução de uma série de atividades de subsistência.

A cadeia produtiva do artesanato Pataxó parece mesmo ocupar bastante gente, e, para a confecção das peças organiza-se toda uma divisão social do trabalho. Nas técnicas, instrumentos e materiais empregados na produção dos artefatos fica bastante evidente a incorporação de alguns elementos modernos, embora rústicos.

A produção [do artesanato] é familiar, havendo uma tendência a uma especialização por sexo e idade na confecção de peças ou parte delas - os homens trabalham com a madeira, talhando-a, enquanto as mulheres cuidam das penas e as crianças dos tecidos em cestarias e acabamentos. A matéria prima, em grande parte, provém da floresta: árvores, cipós, pássaros (papagaios e tucanos), etc., mas entram também na confecção produtos industrializados, como o $Q$-Suco, usado para tingir as penas. As ferramentas são simples: facão, serra, agulhas, faca. Na Coroa Vermelha, os índios compram a matéria prima, seja de outros índios ou de fazendeiros (Rocha Júnior, 1987: 47). 
A antropóloga Leila Soto Maior ${ }^{25}$ afirma que apenas uma pequena parte do artesanato que é vendido em Coroa Vermelha é produzida naquela aldeia. A maior parte seria adquirida dos índios de Barra Velha e Boca da Mata e até mesmo de artesãos não-indígenas.

O panorama descrito por Rocha Júnior em 1987 a cerca da sobrevivência dos Pataxó por meio da venda do seu artesanato, entretanto, denota um quadro de dificuldades vivenciadas por esses índios na época:

Atualmente, o artesanato está em crise, por várias razões: excessiva proliferação do mesmo, a repetição e o desgaste estético, a rarefação e o encarecimento crescente da matéria prima, a competição interna que avilta os preços, a falta de mercados externos e o próprio desgaste da imagem Pataxó, passados já alguns anos de sua "redescoberta" [...]. O órgão tutelar, através da Artíndia, não tem interesse em comercializa-lo, julgando-o de baixa qualidade. Os índios começam a se sentir desesperados e procuram alternativas precárias: incursões a outras praias, como Salvador e Guarapari, vendas em quantidade para órgãos estaduais, como o Instituto Mauá, busca de grandes encomendas junto a lojas, diversificação da produção (adornos carnavalescos, por exemplo), etc. Ao mesmo tempo, revalorizam também as atividades agrícolas, o que reforça suas aspirações por terra. (Rocha Júnior, 1987: 47).

Conforme relata o mesmo autor (Idem), os índios concorriam acirradamente entre eles próprios e com os não-índios pela venda do artesanato aos turistas. Ele inclusive chega a pintar um retrato, a nosso ver, excessivamente dramático, da realidade Pataxó, ao fazer a seguinte afirmação:

[...] a imagem que os Pataxó dialeticamente criaram para si próprios está se revelando demodée e mesmo pouco lucrativa. As condições reais de sobrevivência desse povo estão cada vez mais ameaçadas e restritas; o faccionismo e o individualismo, por sua vez, inibem a emergência de um forte movimento reivindicatório ou de uma unidade política combativa. A inépcia da FUNAI (proverbial) no lidar com essa problemática só fez agrava-la (Rocha Júnior, 1987: 48).

Sampaio aborda em um artigo ${ }^{26}$ a pressão pela restrição de território que sofre Coroa Vermelha e a dependência do artesanato quase que como única fonte de renda. Em linhas gerais, descreve um quadro de dificuldades vivenciadas nesta aldeia:

No caso da Coroa Vermelha, o relativo sucesso desse empreendimento [produção e comércio do artesanato], a forte imigração proveniente de outras aldeias pataxó e o acesso a algumas outras alternativas, inclusive à pesca e à mariscagem, talvez não permitam caracterizar a situação como de fome, mas é bastante perceptível uma sensível

\footnotetext{
${ }^{25}$ Informação fornecida em entrevista realizada no dia 21/12/2006, na sede da FUNAI em Brasília.

${ }^{26}$ SAMPAIO, José Augusto L. Terras e Povos Indígenas do Nordeste: Notas para um Mapa da Fome. In: Mapa da Fome entre os Povos Indígenas no Brasil. INESC - PETI/MN - ANAÍ/BA, 1995.
} 
deterioração das condições de vida, causada pelo incremento populacional e, sobretudo, pelo avanço das invasões e pela falta de saneamento (Sampaio, 1995: 35).

De fato, em Coroa Vermelha, apesar de o cenário não ser de miséria absoluta, existem varias famílias que passam por dificuldades econômicas. Além disso, são perceptíveis os problemas de infra-estrutura, limpeza, segurança, saneamento, iluminação, organização interna e poluição visual do local.

O território da gleba A é bastante reduzido, são cerca de 77 hectares que foram e continuam sendo densamente ocupados de maneira desordenada, o que faz com que a pressão demográfica seja considerada bem alta para o padrão de uma terra indígena. O espaço da Gleba B reservado para a agricultura é insuficiente para atender a contento às necessidades de todas as famílias.

Um censo realizado pela FUNAI em julho de 1998 (Espírito Santo apud Grünewald, 2001:70), registrou uma população de 1.546 indivíduos residentes em Coroa Vermelha, contudo, sabe-se que esse número é impreciso, uma vez que a população dessa aldeia oscila bastante conforme a época do ano. $\mathrm{Na}$ alta temporada do turismo muitas famílias que vivem em outras aldeias se estabelecem em Coroa Vermelha, onde vendem artesanato, retornando à suas aldeias de origem quando a temporada acaba. Grünewald (2001:69) observa que "além de crescer em termos demográficos com as migrações permanentes, Coroa Vermelha é o centro receptor dos pataxós de diversos locais, principalmente no verão. Esse caráter migratório é possibilitado pelo grande fluxo turístico nessa estação, quando as casas de alguns índios ficam abarrotadas de parentes e contraparentes que residem fixamente em outras aldeias".

O diagnóstico sócio-econômico elaborado pela empresa Veracruz Florestal $^{27}$ em 1995 faz a seguinte análise à cerca da situação do povo indígena Pataxó naquele momento:

As características sociais e econômicas do grupo se enquadram na categoria de subsistência cuja sobrevivência depende cada vez mais, da geração de excedentes comercializáveis. A predominância do artesanato, além de inerente à origem do grupo representa uma alternativa concreta de renda e possibilidades de troca por produtos alimentares e manufaturados de uso crescente pelo grupo. A relação com a sociedade ambiente está condicionando mudanças no padrão de consumo, sem a correspondente mudança na organização econômica. Evidencia-se, portanto, a necessidade de redefinir o

\footnotetext{
${ }^{27}$ VERACRUZ FLORESTAL LTDA. As Comunidades Indígenas da Região Sul da Bahia: diagnóstico sócio-econômico. Porto Seguro, 1995. Mimeografado. p.44
} 
padrão de relações do grupo com a sociedade e o sistema tutelar, atualizando-os á sua situação e aos processos sociais a que estão submetidos.

É incontestável o fato de que a interação com a sociedade envolvente ao longo de séculos ocasionou alterações significativas no modo de vida Pataxó que Ihes impuseram novas necessidades de consumo, as quais o sistema organizacional interno do grupo não dá conta de suprir. Desta maneira, eles se vêem cada vez mais dependentes da aquisição de bens e serviços no mercado regional, tendo que, de alguma forma, obter renda monetária. Diante dessa realidade, os Pataxó, sobretudo os de Coroa Vermelha, procuram no turismo e em atividades a ele associadas uma alternativa de subsistência e inserção social.

Não se pode negar que a necessidade econômica foi um fator determinante para o engajamento de um contingente considerável de indígenas na exploração turística na Reserva da Jaqueira, embora houvesse também outras motivações bastante fortes, principalmente de ordem cultural e também ecológica. 


\section{CAPÍTULO 6: O TURISMO NA RESERVA PATAXÓ DA JAQUEIRA}

\section{1 - ALGUMAS CARACTERISTICAS NATURAIS DA RESERVA}

Logo na entrada da Reserva os visitantes se deparam com uma grande Jaqueira, árvore esta que serviu de inspiração para o nome de batismo dessa área, que é composta por 827 hectares inteiramente preenchidos por Mata Atlântica primária em bom estado de conservação e secundária em estágio avançado de regeneração (SIMBIOS, 1999:169).

A Mata Atlântica é o bioma brasileiro que concentra a maior diversidade de espécies vivas. Da área que originalmente ocupava, só restam hoje cerca de $7 \%$, e a degradação desse ecossistema continua em curso apesar dos esforços que os governos e várias entidades representantes da sociedade civil têm feito para evitar que isso aconteça. Assim sendo, a Reserva da Jaqueira assume nos dias atuais um valioso papel na conservação ecológica.

Nesta reserva é possível encontrar, além de uma fauna bastante diversificada (mamíferos, aves, répteis, anfíbios, insetos, etc.), 19 espécies vegetais endêmicas da floresta tropical atlântica, 14 espécies ameaçadas de extinção e 6 vulneráveis (Idem, p.189).

O relevo da área é bastante íngreme e acidentado em alguns pontos. Para que as pessoas possam chegar ao local onde ocorrem as principais atividades turísticas, é preciso enfrentar uma subida razoavelmente acentuada através de uma estrada de terra. No local onde ocorrem tais atividades, o relevo se torna bem mais plano.

A Reserva da Jaqueira compõe, juntamente com outras áreas naturais, um importante corredor ecológico. Segundo Mendonça (2002:65):

O resultado da SIMBIOS (1999:183) apontou que a Reserva da Jaqueira desfruta de excelentes condições naturais. A proximidade da mesma (827 ha), com as áreas da Estação Veracruz (6.040 ha) e a ESPAB - Estação Ecológica do Pau-Brasil (1.145 ha) leva-se a imaginar que a implantação de um corredor ecológico natural levaria a um espaço contínuo que permitisse aumentar a variabilidade das espécies e favorecer grupos que necessitam de áreas extensas de ocupação, aproveitando os vales formados pelas bacias hidrográficas das áreas de ligação. 
Para proteger esse importante patrimônio natural da Reserva, os próprios indígenas mantêm uma equipe para fiscalizar a área e impedir a entrada de caçadores não-índios e outros agentes que possam provocar perturbações. Há também um grupo de aproximadamente dez indígenas que foram capacitados para combater incêndios. A ASPECTUR recentemente esteve reivindicando junto à FUNAI a construção de uma torre de vigilância na Jaqueira, sob a alegação de que a tamanho relativamente grande da Reserva dificulta o total monitoramento e fiscalização terrestre da área.

É importante valorizar o cuidado que os Pataxó têm tido com a Reserva da Jaqueira, uma vez que o importante patrimônio natural que compõe esta área está sob ameaça, uma vez que "os impactos ambientais no seu entorno se intensificam, atingindo a Reserva de duas maneiras: uma vinda do litoral, pela expansão urbana da planície costeira e na borda do tabuleiro, e outra proveniente do interior, devido ao crescimento da agropecuária, principalmente plantios de coco e pastagens de braquiária, com ameaça de queimadas e incêndios florestais". (ASPECTUR, 2007:14).

\section{2 - A IMPLEMENTAÇÃO DO TURISMO E SUAS MOTIVAÇÕES}

Quando os indígenas ocuparam a Reserva da Jaqueira, seu objetivo inicial era utilizar a área como um espaço de promoção e resgate de práticas tradicionais da cultura Pataxó, o que, de fato, tem sido feito. Um bom exemplo disso são as aulas da língua Patxohã que são ministradas na Reserva, principalmente para as crianças. Logo os índios perceberam que a reserva também tinha um grande potencial para a exploração do ecoturismo, e com a permissão do cacique de Coroa Vermelha, começaram então a desenvolver a atividade, ainda de forma tímida no começo.

Segundo recordam os próprios índios, a exploração turística na Reserva da Jaqueira teve início exatamente no dia $1^{\circ}$ de agosto de 1998, quando recepcionaram os estudantes de uma escola do município vizinho de Teixeira de Freitas.

A iniciativa de explorar comercialmente o turismo foi tomada por cerca de 30 indígenas. Em 25 de janeiro de 1999, foi fundada a ASPECTUR, associação 
comunitária, sem fins lucrativos, cuja finalidade principal é organizar a exploração turística e captar recursos para desenvolver a atividade.

Segundo Nayara Pataxó, uma das fundadoras da ASPECTUR, a idéia de explorar o ecoturismo na reserva foi motivada, em primeiro lugar, pela necessidade de promover a afirmação e o fortalecimento da identidade cultural dos Pataxó por meio de iniciativas desenvolvidas no local que valorizassem a cultura tradicional desse povo. A necessidade de geração de ocupação e renda para a comunidade e o intuito de conservar a área de mata nativa também influenciaram significativamente a decisão do grupo.

Com o tempo, o projeto da Reserva da Jaqueira foi se consolidando como um roteiro turístico local e um maior número de indígenas oriundos de Coroa Vermelha foi se inserindo nele. Atualmente, o número de indígenas que trabalham na reserva é de aproximadamente 95 indivíduos (entre crianças, jovens e adultos, de ambos os sexos), porém, segundo o que fomos informados, apenas duas famílias residem de fato naquele local, os demais índios, principalmente os jovens, que estudam na cidade, moram na Gleba A de Coroa Vermelha, porque esta aldeia tem melhor infraestrutura e de lá o acesso é mais fácil até o local de estudo.

Pessoas envolvidas no projeto de ecoturismo da Jaqueira alegam que, nos últimos anos, têm resistido a pressões por parte de alguns indivíduos da própria comunidade indígena de Coroa Vermelha que tencionam ocupar parte da área de mata para fazer roças e construir moradias. Contudo, acredita-se que em breve algumas retomadas de terra dos Pataxó na região devem ser regularizadas pelo Governo Federal, o que aumentaria a área disponível para o extrativismo e os cultivos agrícolas do grupo, fazendo diminuir a pressão sobre a área de mata, pelo menos, pelos próximos anos.

\section{3 - A VISITAÇÃO E SUAS REGRAS}

A Reserva da Jaqueira fica aberta para a visitação de segunda a sábado, das 09:00 às 17:00. Diariamente podem ser oferecidos dois passeios, para um público máximo de cinqüenta pessoas em cada passeio, que tem duração média de três horas. Os turistas são subdivididos em grupos que variam entre dez e quinze 
pessoas, que se revezam na visitação dos diferentes atrativos da Reserva. Cada um desses subgrupos é acompanhado por dois guias indígenas devidamente capacitados.

A seletividade na quantidade de pessoas permitida em cada passeio se explica pela preocupação dos guias indígenas em minimizar os impactos ambientais oriundos da visitação. Os Pataxó tem consciência de que a extrapolação da capacidade de carga do local visitado acarretaria sérios danos ao meio-ambiente. $\mathrm{O}$ barulho provocado pelo excesso de turistas circulando na mata poderia afugentar e estressar os animais silvestres, acarretando modificações nos seus hábitos e comportamentos. Nas trilhas, o pisoteamento contínuo tenderia a provocar impactos na vegetação e no solo, tal como enumera Dias (2003:93): queda ou dano nas hastes ou caule das plantas; redução do vigor das plantas; redução da capacidade de regeneração da vegetação; ocorrência da perda da cobertura do solo; alteração na composição das espécies; perda da matéria orgânica, redução da porosidade e aumento da impermeabilidade do solo; aceleramento do processo de erosão.

Se ocorressem tais impactos acima mencionados, certamente isso implicaria na perda da biodiversidade e, conseqüentemente, na deterioração do potencial turístico do local.

Outra razão para a limitação do número de visitantes e da divisão destes em pequenos grupos é entendimento de que desta forma os guias indígenas podem dar mais atenção aos turistas e transmitir melhor as informações do roteiro.

Antes mesmo de iniciar o passeio, os guias Pataxó conversam com os turistas sobre a relação de sua comunidade com o meio ambiente, sobre a importância de preservar a natureza e explicam as normas de conduta dentro do recinto. Dentre as regras de visitação, está colocado que é proibido descartar lixo no chão e ao longo das trilhas, fumar e portar bebidas alcoólicas. 
Quase todos os ambientes da Reserva estão liberados para visitação pública, com exceção dos Kijemes ${ }^{28}$ utilizados pelas famílias indígenas como moradia e dos locais considerados sagrados pelos Pataxó, onde o acesso é restrito aos membros do grupo étnico; medida esta, que mostra uma preocupação dos índios em assegurar a preservação do local e a privacidade do grupo. Os Kijemes que não são habitados, no entanto, podem ser visitados sem restrições.

Após a conversa inicial, os grupos de turistas são subdivididos (podendo chegar até quatro grupos pequenos, dependendo da quantidade de pessoas no passeio) e seguem acompanhando os guias pelas trilhas na mata. São três as trilhas existentes na reserva. Todas são consideradas de nível médio de dificuldade e são sinalizadas com placas informativas, visando propiciar ao visitante, informações sobre o percurso e o bioma. Nesse percurso os guias apresentam aos turistas alguns exemplares da flora e da fauna local, explicando a sua funcionalidade. São mostradas também réplicas de armadilhas utilizadas para capturar animais na mata. Em seguida, os turistas são levados a conhecer os cultivos agrícolas dos índios, a sua plantação de ervas medicinais e o viveiro de aproximadamente quinhentas mudas de espécies endêmicas da Mata Atlântica - algumas ameaçadas de extinção, como o Jacarandá e o Pau-Brasil - além de outras espécies que fornecem a madeira e as sementes para a confecção do artesanato. Os turistas também são convidados a plantarem as mudas. As mudas cultivadas são destinadas à recuperação de áreas degradadas da Mata Atlântica.

Nessas atividades, os turistas se integram ao cotidiano dos índios e ampliam o seu repertório cultural, ficam conhecendo a relação que aqueles índios estabelecem com o meio natural, conhecendo também parte da diversidade biológica da Mata Atlântica e ainda são incentivados a tomarem iniciativas concretas no sentido de conservar a natureza.

Após essa etapa os visitantes assistem a uma palestra de cerca de 20 minutos em que os índios falam a respeito do seu modo de vida tradicional, suas crenças,

\footnotetext{
${ }^{28}$ Os kijemes são pequenas casas construídas sob os moldes da arquitetura tradicional dos Pataxó, com paredes de taipa e troncos de madeira e cobertura de palha de coqueiro.
} 
suas tradições, suas lendas e sua cultura de maneira geral. Em seguida, os turistas são convidados a conhecer a gastronomia típica dos Pataxó, podendo degustar a tapioca, o peixe assado envolvido na folha da patióba ${ }^{29}$ (mukussuy) e saborear o cauim, bebida tradicional à base de mandioca fermentada.

Na seqüência, os índios fazem demonstrações no jogo de arco-e-flecha, dançam e cantam o awê, onde o turista também é convidado a participar. E tem até aqueles turistas que pedem para ser pintados iguais os índios. O awê é tido como a dança mais característica dos Pataxó. No site da Secretaria de Turismo de Porto Seguro ${ }^{30}$ há um verbete explicativo sobre esta dança, escrito provavelmente por um indígena, que diz o seguinte:

O Awê para nós Pataxó significa o amor, a união e a espiritualidade com a natureza. $O$ Awê nos traz segurança e a dança e o canto são instrumentos de comunhão entre nós Povo Pataxó e a natureza. Através do canto e da dança transpiramos e adquirimos novas energias da terra, do ar, da água, do fogo e de todas as energias positivas que formam a natureza.

Outra manifestação cultural apresentada pelos Pataxó aos turistas é o Toré, ritual acompanhado de dança que se tornou a expressão mais típica dos índios da região Nordeste.

Por último, os convidados são levados para conhecer o Kijeme onde ficam expostos os produtos artesanais, ocasião em que podem adquirir as peças. $\mathrm{O}$ artesanato colocado à venda é bem diversificado e os artefatos são vendidos a um valor mais alto do que na praia de Coroa Vermelha, até porque as apresentações artísticas e rituais ajudam a agregar valor às peças de artesanato. Ao visualizar as funções do uso dos artefatos nas apresentações dos índios, o turista atribui maior capital simbólico a esses artefatos e se dispõe a pagar um maior preço por eles. É possível encontrar desde lanças, bordunas, arco-e-flexas, até colares feitos de sementes, gamelas de madeira polida e essências feitas com substrato extraído da Amesca ${ }^{31}$.

A essa altura do passeio, os turistas interagem fortemente com a cultura indígena, desenvolvendo, geralmente, um sentimento de simpatia em relação a ela.

\footnotetext{
${ }^{29}$ A Patióba é uma espécie de palmeira abundante na Mata Atlântica.

${ }^{30}$ http://www.portosegurotur.com.br/porto_lazer-jaqueira2-3.htm

${ }^{31}$ A Amesca é uma espécie de árvore cuja resina extraída da seiva é utilizada por muitos povos indígenas em rituais de cura.
} 
Isso serve para incutir na mente do turista uma representação positiva das sociedades indígenas de maneira geral e desmistificar os estereótipos pejorativos que a indústria cultural insiste em disseminar.

Ao participar de tantas atividades, é comum que os turistas sintam a necessidade de se hidratar. Nesse caso, eles podem adquirir garrafas d'água de $300 \mathrm{ml}$, em temperatura natural, que os Pataxó colocam à venda por um preço unitário de $\mathrm{R} \$$ 2,00 . Os guias orientam os turistas a descartarem as garrafas plásticas de água, assim como o restante do lixo produzido, nos cestos de lixo, feitos de palha trançada em estilo indígena, que se encontram espalhados pela Reserva. Nada deve ser jogado no chão.

Encerrado o passeio, os turistas são acompanhados até o portal da Reserva da Jaqueira e voltam para o local onde estão hospedados.

No passeio programado não está previsto o pernoite de turistas, mas os indígenas relataram que já houve casos em que, mediante o pagamento de um valor adicional, permitiram por vezes que turistas dormissem na Reserva, fato que pode ser preocupante, uma vez que a permanência prolongada do turista pode provocar uma interferência excessiva no cotidiano dos índios.

Os próprios índios mantêm um sistema de controle de visitação dos turistas que vão à Reserva da Jaqueira. Eles anotam dados com nome, endereço e telefone dos visitantes, mas, segundo Mendonça (2002:68), "destes dados, pouco tem sido utilizado para se extrair informações estatísticas que os ajudem na gestão do empreendimento". A montagem de banco de dados dos visitantes poderia, de fato, ajudar no planejamento e no monitoramento das estratégias de gestão.

\section{4 - INFRA-ESTRUTURA E CONDIÇÕES DE ACESSO}

A Reserva da Jaqueira dista apenas 12 quilômetros do centro de Porto Seguro. Parte do percurso da cidade até a reserva é feito pela Estrada do Côco, que é asfaltada, e outra parte (de aproximadamente $2 \mathrm{~km}$ ) é de estrada de terra. Esta última costuma ficar em más condições de tráfego quando chove forte, principalmente no verão. Mendonça (2002:90) constatou que "o acesso à área é condicionado à época 
da chuva, uma vez que a estrada fica ruim formando um lamaçal, chegando até mesmo a desestimular a visitação, porém, na época da seca a estrada é boa".

Não existe nenhuma linha regular de ônibus urbano que transporta as pessoas até o local. Isso é ruim, nem tanto para os turistas, que costumam a serem fretados pelos ônibus e vans das empresas de turismo ou por carro próprio, mas mais para os índios que trabalham na Jaqueira e residem na aldeia de Coroa Vermelha, a seis quilômetros dali. Esses índios são transportados pela caminhonete da associação ou perfazem o trajeto a pé.

Ao chegarem na Reserva, os turistas e as operadoras turísticas podem estacionar seus veículos no pequeno pátio que existe em frente ao portal. A entrada de veículos automotores é proibida, a não ser em casos que envolvam o transporte de pessoas que tem dificuldades de locomoção. A proibição tem um caráter de medida ecológica, já que a presença de veículos no interior da reserva ocasionaria a queda da qualidade do ar provocada pela emissão de carbono e o barulho dos motores assustaria os animais que vivem na mata.

Em termos de infra-estrutura adaptada ao turismo, a Reserva Jaqueira conta com placas de sinalização nas entradas das trilhas e corrimão ao longo delas para evitar maiores acidentes. Os onze Kijemes temáticos existentes foram construídos segundo uma concepção arquitetônica típica das populações indígenas, com estrutura de madeira e cobertos por piaçava, e estão harmonizadas esteticamente com o ambiente do lugar. Possuem uma estrutura reforçada, capaz de abrigar as pessoas com segurança em caso de uma chuva mais forte. Logo na entrada da reserva está instalado um pequeno quiosque onde funciona o centro de informações turísticas. Há também uma pequena edificação com dois banheiros (feminino e masculino) que os turistas podem utilizar. Esses banheiros são munidos de fossas sépticas e caixas d'água, abastecidas por bomba d'água. A manutenção das instalações existentes na reserva é executada pela própria ASPECTUR, através de uma equipe de índios designada por ela.

Lideranças Pataxó estiveram recentemente em Brasília, na sede da Funai, reivindicando, entre outras coisas, a construção de uma torre de vigilância e de uma 
ponte suspensa na Reserva da Jaqueira. A torre seria um ponto de fiscalização de incêndios e da entrada de invasores na área; já a ponte suspensa teria a função de ser mais um atrativo turístico.

$\mathrm{Na}$ Reserva da Jaqueira não existe nenhum centro de atendimento emergencial instalado caso haja alguma ocorrência de acidente ou problema de saúde com alguém. Felizmente, nunca foi registrado nenhum caso em que houvesse essa necessidade. Como a reserva não fica muito longe da cidade, em caso de emergência, o deslocamento até o hospital mais próximo em condições normais não demora mais de meia hora.

\section{5 - O PERFIL DO TURISTA}

O número de visitantes na Reserva da Jaqueira tem crescido a cada ano. A ASPECTUR registrou a visitação de mais de 7 mil pessoas no ano de 2006 (ASPECTUR, 2007:04).

Segundo os indígenas que trabalham no projeto da Jaqueira, são muitos os turistas brasileiros que procuram o local, principalmente os que vêm da região Sudeste, mas a maior quantidade dos freqüentadores da reserva é mesmo de estrangeiros; europeus em sua maioria (holandeses, franceses, portugueses, italianos, espanhóis, etc.). Como muitos desses estrangeiros não falam português, as agências ou os hotéis que levam esses turistas até o local se encarregam de providenciar tradutores para os acompanharem. Alguns guias indígenas, porém, já começam a estudar idiomas estrangeiros na perspectiva de poderem futuramente se comunicar diretamente com turistas vindos de países do exterior sem necessitar de intermediários, entendendo que, dessa maneira, a compreensão de parte a parte ficaria facilitada.

Mesmo sem termos realizado nenhuma pesquisa para o levantamento do perfil do turista que visita a Jaqueira, é possível supor que, na maioria dos casos, trata-se de pessoas que têm um nível cultural relativamente elevado, já que se interessam por destinos turísticos alternativos ao modelo convencional do "sol e praia", e demonstram uma preocupação mais acentuada com os problemas sociais e 
principalmente ambientais. Supõe-se também que esse turista possui um alto poder aquisitivo se comparado à média da população nacional, pois as camadas populares dificilmente se dispõem a desembolsar $\mathrm{R} \$ 35,00$ ou mais pela visitação de um atrativo turístico.

São raros os moradores do município ou da região que manifestam interesse em fazer os passeios na reserva, a não ser os grupos organizados por escolas. A maior parte do público visitante, como já foi dito anteriormente, é composta mesmo por freqüentadores turísticos das cidades da região, atraídos principalmente pelas praias e pelo patrimônio arquitetônico histórico. Essas pessoas, muitas vezes, só chegam a tomar conhecimento de que existe uma comunidade indígena em Porto Seguro quando chegam na região. Sabendo da existência dos passeios na Reserva da Jaqueira, acabam se interessando.

Leme e Trevisan (2006:109) entendem que o sucesso de um empreendimento como a Reserva da Jaqueira em um local conhecido pela receptividade do turismo "praia e sol", como é o caso de Porto Seguro, pode ser um indício de mudança que vem se realizando aos poucos no turismo de massa.

A maioria dos turistas, particularmente os que praticam o chamado "turismo de massa", em locais já bastante explorados pela atividade e onde terá preços reduzidos, não tem ainda uma visão tão ampla de quão interessante pode ser a cultura do outro, como tem os $\operatorname{cosmopolitas}^{32}$. No entanto, há indícios de que isto já está mudando. Testemunha disso são os passeios do Projeto Jaqueira onde os turistas, em um destino onde é realizado o turismo de massa (Porto Seguro), pagam uma quantia não tão pequena para entrar na reserva indígena [...] (LEME e TREVISAN, 2006:109).

Os passeios turísticos na Jaqueira são mais freqüentes no período entre novembro e fevereiro e em julho. Os meses de março, abril, maio e agosto são os de menor visitação (Mendonça, 2002:68). Isso demonstra que a sazonalidade do turismo na Costa do Descobrimento afeta o empreendimento, já que a visitação nele oscila de acordo com a alta e a baixa temporada turística na região.

Quanto ao comportamento do turista, na ocasião de nossa visita técnica, os indígenas entrevistados foram unânimes em afirmar que dificilmente ocorrem casos

\footnotetext{
32 Leme e Trevisan se utilizam nesse caso da concepção de “turistas cosmopolitas” formulada por Hanners (1999). Este último denomina por "cosmopolitas aqueles turistas que se orientam, acima de tudo, pelo convívio com povos e culturas diferentes”.
} 
de desrespeito em relação à cultura indígena e ao regulamento da Reserva da Jaqueira, no entanto, Mendonça, em sua pesquisa de mestrado constatou que:

[...] para o verificador comportamento preconceituoso de visitantes, registrou-se que os mesmos chegam, de modo geral, ao empreendimento com visão distorcida em relação aos hábitos culturais [dos índios], ocasionado pela falta de conhecimento, pelo imaginário de encontrar índios nus como a quinhentos anos atrás, entre outras opiniões, formando desse modo um estereótipo negativo (MENDONÇA, 2002:79).

A citação colocada acima parece estar em contradição com o que Melo (2005:72) constatou a partir da fala da indígena Pataxó Maria das Neves Nitinawã, então presidente da ASPECTUR, em palestra no fórum mundial de turismo no Rio de Janeiro em 2005:

Segundo Maria das Neves, $\mathbf{9 0 \%}$ dos visitantes [da Reserva da Jaqueira] são estrangeiros e a grande maioria destes já chegam à aldeia com uma consciência de respeito e preservação da cultura e do meio-ambiente e, muitas vezes, com o intuito de ajudar a comunidade de alguma forma (MELO, 2005: 71).

6.6 - PARCERIAS E APOIOS INSTITUCIONAIS PARA A PROMOÇÃO E O DESENVOLVIMENTO DO TURISMO

A ASPECTUR trabalha em parceria com quatro agências de viagens de Porto Seguro (Taipe, Brasil Travel, Pataxó Turismo e Terra Turismo), embora não tenha contrato assinado com nenhuma delas. O tipo de relacionamento que a associação mantém com as agências é de comissionamento: as agências se responsabilizam pelo transporte dos turistas até a reserva e da reserva para dentro, a responsabilidade é da ASPECTUR; a venda dos pacotes de visitação é feita pelas agências, que cobram o preço que elas mesmas estipulam e repassam para a associação indígena um valor fixo de $\mathrm{R} \$ 35,00$ por pacote vendido.

Além das visitações promovidas em parceria com as agências, a ASPECTUR permite a visitação de grupos turísticos independentes, desde que combinado com antecedência. Nesse caso, o visitante paga diretamente aos índios a taxa de $\mathrm{R} \$$ 35,00 .

A ASPECTUR recebe apoio de alguns órgãos governamentais e outras instituições, inclusive do setor privado. O IBAMA, por exemplo, desenvolveu cursos de capacitação para os índios em educação ambiental, fiscalização e combate e prevenção de incêndios florestais (este último através do PREVFOGO). O Ministério 
do Meio Ambiente (através do PROECOTUR ${ }^{33}$ ), em 2001, investiu recursos na reforma e construção de instalações da Reserva da Jaqueira, na sinalização, na confecção de materiais de publicidade, entre outros. Ao todo, o PROECOTUR investiu R\$ 130 mil através do Projeto de Desenvolvimento Sustentável e Preservação da Mata Atlântica da Reserva da Jaqueira, aprovado em 2000 (ASPECTUR, 2007:04). O IPHAN, segundo Mendonça (2002:111) patrocinou a construção de um módulo de sanitários no empreendimento. Em 2005, a Bahiatursa, órgão do Governo da Bahia para a promoção, fomento e desenvolvimento do turismo no Estado, desenvolveu um curso de capacitação de monitores de turismo para 40 índios Pataxó ${ }^{34}$. O Núcleo de Apoio Local da FUNAl em Porto Seguro tem editado desde outubro de 2005 um jornalzinho de circulação local bimestral chamado "Awê Pataxó", que costuma a divulgar em suas edições os passeios turísticos da Reserva da Jaqueira. A FUNAI tem ajudado também na compra de materiais para a fiscalização da reserva e combate a incêndios. A Secretaria Municipal de Turismo de Porto Seguro faz publicidade do turismo na Reserva em seu site ${ }^{35}$. Em 2004, a Veracel Celulose, empresa privada que opera na região, doou uma caminhonete S10 diesel para o transporte dos indígenas. Luíndia (2004:07) menciona que o proprietário de uma das agências de turismo que operam em parceria com os Pataxó recebe doações de grupos estrangeiros que são repassadas ao projeto da Jaqueira. Em 2002, o projeto teria recebido US $\$ 600$, e em 2003 US $\$ 800$.

Mendonça registrou em sua dissertação de mestrado ${ }^{36}$ que havia um entendimento da direção da ASPECTUR, de que o Núcleo de Apoio Local da FUNAI na região prestava um apoio muito insuficiente ao empreendimento da Reserva da Jaqueira. Diz esse autor o seguinte:

A relação da Funai regional com o empreendimento não é o que se espera do órgão oficial da política indigenista no tocante ao apoio no desenvolvimento das comunidades indígenas. [...] Poderia, mesmo sem as condições de recursos humanos, financeiros, entre outros, prestar assistência administrativa do projeto, tirando dúvidas e prestando esclarecimentos via telefone. Vez por outra fazer uma visita em campo para identificar

\footnotetext{
33 PROECOTUR (Programa de Desenvolvimento do Ecoturismo na Amazônia Legal).

${ }^{34}$ Fonte: <http://www.sierramar.com.br/noticias/visualizar.asp?Cod=17>.

$35<$ http://www.portosegurotur.com.br/porto_lazer-jaqueira2.htm>

${ }^{36}$ MENDONÇA, Roberto Costa e Silva. Associação Pataxó de Ecoturismo - Reserva da Jaqueira, Porto Seguro, Bahia: facilidades e restrições para a sua sustentabilidade. Dissertação (Mestrado em Desenvolvimento Regional e Meio Ambiente) Universidade Estadual de Santa Cruz, Ilhéus, 2002.
} 
necessidades e buscar solução para a ASPECTUR. Os dirigentes da Associação ressentem-se da ausência desse órgão no empreendimento (MENDONÇA, 2002:102).

É possível que, da época que Mendonça escreveu para os dias atuais, a relação da ASPECTUR com a FUNAI local tenha melhorado. Talvez, a edição do jornalzinho Auê Pataxó seja uma prova disso. Contudo, essa hipótese não pôde ser verificada com precisão por nós. Uma coisa que dificulta o apoio formal e mais constante da FUNAI ao empreendimento é a inexistência até o momento de uma regulamentação das atividades turísticas em terras indígenas, já que as ações do órgão precisam estar fundamentadas juridicamente.

Além do apoio das instituições já mencionadas, existem também parcerias para a divulgação do empreendimento e promoção do turismo. No site da Secretaria de Turismo de Porto Seguro (www.portosegurotur.com.br), por exemplo, é possível encontrar um link exclusivo com informação sobre os passeios turísticos na Reserva da Jaqueira. No próprio site do Ministério do Turismo, dentro do link de divulgação de Porto Seguro, está mencionado o turismo na Reserva. Há outros vários endereços eletrônicos de hotéis e agências de turismo locais que também divulgam o turismo indígena.

Segundo os índios, o fato de contarem com parcerias e ajuda externa não compromete a autonomia da comunidade na concepção do projeto turístico, no seu planejamento e na tomada de decisões nos assuntos de seu interesse. De acordo com um dos indígenas integrantes da ASPECTUR, eles já chegaram a recusar uma proposta da operadora CVC turismo, que pretendia levar diariamente 300 turistas para conhecer a Reserva, o que certamente ocasionaria uma saturação da capacidade de carga do ambiente.

Os indígenas com os quais conversamos nos contaram sobre o plano da ASPECTUR em montar um quiosque no centro histórico de Porto Seguro, ou na praia, para fazer a divulgação turística da Reserva da Jaqueira, o que ainda estava dependendo de autorização da prefeitura do município. 


\section{7 - GESTÃO DOS RECURSOS E REPARTIÇÃO SOCIAL DOS BENEFÍCIOS}

Hoje em dia a ASPECTUR conta com um quadro de 9 funcionários que recebem remuneração fixa, são eles: presidente, vice-presidente, $1^{\circ}$ e $2^{\circ}$ secretários, $1^{\circ}$ e $2^{\circ}$ tesoureiros e mais 3 fiscais ambientais. As demais pessoas que trabalham no projeto da Jaqueira não possuem um vínculo empregatício formal com essa associação. Estas são chamadas de "voluntários", embora geralmente consigam auferir algum rendimento a partir do seu trabalho.

A arrecadação obtida pelos índios com a venda dos ingressos de visitação e de outros produtos na Reserva da Jaqueira é centralizada pela ASPECTUR, que, por sua vez, desconta uma parte desse valor para o pagamento de suas despesas, repassa uma outra parcela aos "voluntários" Pataxó que trabalham com o ecoturismo na reserva e reinveste o restante na manutenção do próprio empreendimento. Às vezes sobra um dinheiro para ser destinado à ajuda para a comunidade de Coroa Vermelha (MENDONÇA, 2002:73). De acordo com uma estimativa da própria ASPECTUR: "O orçamento médio mensal da associação está na faixa de $R \$ 7.500$ e abrange despesas como alimentação, salário de funcionários, combustível, telefones fixo e móvel" (ASPECTUR, 2007:04).

Os valores que cada trabalhador "voluntário" aufere individualmente com a exploração do turismo são insuficientes para o sustento de uma família. Por isso mesmo é que as pessoas costumam a se dedicar simultaneamente a outras atividades produtivas, evitando, deste modo, uma dependência exclusiva do turismo.

Mendonça (2002:70) traça o seguinte panorama a cerca do processo de repartição dos benefícios financeiros entre os índios:

Há remuneração proporcional à participação de cada um, só que antes de acontecer essa divisão é retirada a parcela correspondente à manutenção e o funcionamento do empreendimento. Chamou-se a atenção que a remuneração beira ao voluntariado, que por força de vontade continuam no empreendimento, pois acreditam que a sustentabilidade econômica é uma questão de tempo e de trabalho.

Os valores obtidos com a venda das peças de artesanato na reserva são repassados diretamente aos produtores. A confecção desses artefatos é permitida a 
todos. Quase todas as famílias envolvidas no empreendimento têm seu estande no Kijeme que funciona como centro de vendas de artesanato.

Em sua dissertação de mestrado ${ }^{37}$, Mendonça constata a existência de um indicador que pode contribuir de forma importante para a sustentabilidade econômica do empreendimento ecoturístico: a distribuição eqüitativa dos benefícios.

[...] os entrevistados registraram que existe equidade na distribuição dos resultados do empreendimento e que essa distribuição fica a cargo da associação, sem interferência alguma de quem quer que seja. Os Pataxó contestaram a tese de que há marginalização por parte da comunidade quanto ao recebimento dos benefícios. Contudo, por serem insuficientes, somente os associados são beneficiários até o momento, recebendo proporcionalmente, ao trabalho desempenhado, esses benefícios financeiros. Contudo a comunidade, como um todo, não é esquecida, sendo beneficiada através de doações e compras de materiais para a escola, principalmente. Os entrevistados negaram que haja Concentração de Renda nas famílias das lideranças e fizeram questão de ressaltar que há igualdade nessa distribuição, sem privilégios de qualquer espécie (Mendonça, 2002: 84-85).

Por outro lado, a situação que Luíndia (2004:07) relata é bem diferente. Segundo o que esta autora constatou, há desigualdade na repartição comunitária dos lucros do projeto. Os líderes estariam ganhando mais do que todos; em seguida viriam os associados da ASPECTUR que mais se destacavam e por último na divisão dos lucros, estaria o restante dos trabalhadores. A autora também comenta que, em conversa que teve com alguns "voluntários" que trabalham no projeto, os mesmos se mostraram descontentes com a porcentagem recebida e se queixaram de atrasos nos pagamentos. A autora registra ainda que, durante as visitas que fez à Reserva da Jaqueira em 2003 e 2004, observou que muitos jovens estavam deixando o empreendimento turístico para buscar outra fonte de renda.

Luíndia (2004:28), por fim, conclui que há sérios obstáculos para que a Reserva da Jaqueira se torne um empreendimento sustentável:

En el caso Pataxó, se observó una falta de confianza y de lazos sociales entre los dirigentes y los trabajadores, bien como en relación a los otros indígenas a respecto del proyecto. Los trabajadores llamados de voluntarios por la ASPECTUR por no recibieren sueldos substanciales a ejemplo de los líderes, no se involucran de manera efectiva en el proyecto, principalmente, porque las ganancias mayores se quedan apenas con los líderes. Todos trabajan, todos tienen sus responsabilidades mismo siendo diferentes cada una, pero sólo los costos son divididos y entre "los voluntarios".

\footnotetext{
37 MENDONÇA, Roberto Costa e Silva. Associação Pataxó de Ecoturismo - Reserva da Jaqueira, Porto Seguro, Bahia: facilidades e restrições para a sua sustentabilidade. Dissertação (Mestrado em Desenvolvimento Regional e Meio Ambiente) Universidade Estadual de Santa Cruz, Ilhéus, 2002.
} 
Um outro problema que tem causado certa insatisfação entre alguns Pataxó é que o empreendimento só tem conseguido absorver como mão-de-obra uma pequena parcela de indivíduos da comunidade da aldeia de Coroa Vermelha. Alguns indígenas de Coroa Vermelha estariam se queixando de que o projeto da Reserva da Jaqueira inclui poucas pessoas e deixa de incluir a maior parte da comunidade. Leme e Trevizan ${ }^{38}$ constatam que "Para muitos Pataxós, a inclusão no projeto [de ecoturismo na Reserva da Jaqueira] de apenas algumas famílias é um erro grave que acarretou brigas entre os próprios índios". Estes mesmos autores ${ }^{39}$ registram o descontentamento do índio Taquari que teria afirmado que "os [indígenas] que elaboraram o projeto e seus gestores não levaram em conta uma questão primordial na cultura indígena atual: a solidariedade para com os outros 'parentes' que são os membros das comunidades vizinhas". Taquari também teria dito que "na reserva de Coroa Vermelha ficou o sentimento de incômodo pelas diferenças de oportunidades geradas". ${ }^{40}$

As lideranças do projeto da Jaqueira, no entanto, negam que haja um sentimento generalizado de insatisfação por parte dos demais índios da comunidade de Coroa Vermelha. Afirmam que, pelo contrário, o projeto é até bem visto pelo restante dos indígenas que não participam dele, pois parte da arrecadação é investida em benfeitorias, que beneficiam a comunidade como um todo, como melhorias no posto de saúde e na escola da aldeia.

O problema da exclusão de membros da comunidade no projeto de ecoturismo é de difícil solução, pois se hoje em dia os rendimentos obtidos com a exploração do ecoturismo são insuficientes para garantir por si só a sobrevivência das cerca de 95 pessoas envolvidas com o projeto, mais difícil ficaria a situação se um contingente maior de indígenas se incorporasse a ele.

O ideal seria que estivessem em curso outros projetos de desenvolvimento comunitário para a população de Coroa Vermelha, para que fosse possível

\footnotetext{
38 LEME, Fernanda B. M.; Trevizan, Salvador D. P. O Resgate da Identidade Cultural: meio para uma sustentabilidade local. In: Interações Revista Internacional de Desenvolvimento Local. Vol. 7, № 12, p. 101-110, Campo Grande-MS: UCDB, Mar. 2006. p. 107. ${ }^{39}$ Idem.

${ }^{40}$ Idem.
} 
proporcionar renda para um maior número de pessoas, além de diversificar o potencial de atividades produtivas daquela comunidade. 


\section{CONSIDERAÇÕES FINAIS}

Como vimos anteriormente, o povo Pataxó, ao longo de séculos de contato com a sociedade envolvente, sofreu uma série de compulsões e foi coagido a abandonar paulatinamente os hábitos culturais indígenas, a se miscigenar e a aderir aos costumes da população regional. Com o passar do tempo, o grupo que era nômade e vivia disperso nas matas, sobrevivendo da caça e da coleta foi forçado a se concentrar em aldeias fixas e se sedentarizar; a língua Pataxó original deixou de ser praticada e se perdeu; as danças e as crenças foram sendo deixadas de lado, o sistema econômico tribal foi se desorganizando em detrimento da inserção dos índios na economia de trocas regional e no mercado de trabalho, e assim os índios foram se descaracterizando em relação ao que eram originalmente.

Nas últimas décadas, no entanto, observa-se entre os Pataxó o fortalecimento de um movimento de resgate cultural, de reconstrução das tradições e de afirmação da identidade indígena. Exemplos concretos disso são: a produção do artesanato com motivos indígenas, a criação de padrões de pintura corporal, a adoção de nomes indígenas e as tentativas de resgate e recriação de uma língua Pataxó, o Patxohã.

Quando a cidade de Porto Seguro se consagrou como destino turístico de massa a partir dos anos 1970, e mais intensamente a partir da década seguinte, o contato dos Pataxó com turistas vindos de outras regiões do Brasil e de países do exterior se tornou um fato constante, até mesmo porque a praia de Coroa Vermelha, onde havia uma grande aldeia instalada, se tornou um dos pontos mais visitados da região, exatamente por ser o local de descobrimento do Brasil.

O contato com os turistas, ainda que involuntariamente, produziu um incentivo para a reconstrução da identidade Pataxó, pois estes índios passaram a valorizar cada vez mais a sua especificidade étnica nas representações que faziam na arena turística através da adoção de sinais diacríticos que os caracterizavam como indígenas segundo o imaginário popular.

A reconstrução dos elementos simbólicos afirmadores de uma tradição cultural Pataxó, no entanto, não pode ser vista como um processo ilegítimo, até porque toda e qualquer cultura é dinâmica, isto é, sofre mutações o tempo todo, e as tradições são constantemente reinterpretadas. Aquilo que os Pataxó apresentam na arena 
turística não é um mero simulacro; é uma manifestação espontânea e autêntica, uma vez que o sentimento de pertencimento a uma etnia diferenciada transcende ao convívio com os turistas, permeando a vivência cotidiana dessa população.

Está claro que o modelo de turismo que os Pataxó exploram está intimamente conectado com a dimensão cultural, mesmo porque o exotismo da sua cultura é justamente o diferencial que faz desse grupo indígena por si só um atrativo turístico. A exposição turística consegue dar uma visibilidade significativa para esses indígenas enquanto atores sociais distintos. Não há como negar também que a necessidade econômica foi e continua sendo um fator decisivo na motivação dos Pataxó em se engajarem na exploração do turismo. A renda auferida com atividades correlatas ao turismo, principalmente a venda do artesanato, em se tratando da comunidade de Coroa Vermelha, acabou por se tornar o principal meio de sustento de uma população que vive em condições consideravelmente precárias e que não dispõe de muitas alternativas econômicas.

O programa de turismo desenvolvido na Reserva da Jaqueira, por sua vez, ressalta, acima de tudo, os aspectos da cultura Pataxó, mas tem também um viés conservacionista. Nesse espaço, que é uma reserva ecológica, optou-se por desenvolver o ecoturismo, por ser esta uma atividade que possibilita a geração de recursos financeiros sem causar muita degradação no ambiente natural. Na ocasião das visitas turísticas, trabalha-se a conscientização e a sensibilização das pessoas por meio da educação ambiental e das mostras dos costumes e tradições Pataxó.

O modelo de turismo que os Pataxó desenvolvem na Reserva da Jaqueira, desde que aperfeiçoado e bem orientado, tem um grande potencial para se tornar uma experiência que esteja em consonância com a concepção que a Embratur (1994:19) tem a respeito do ecoturismo; isto é, um segmento do turismo que promove o uso sustentável do patrimônio natural e cultural, incentiva a conservação da natureza e a formação de uma consciência ambientalista e promove o bem-estar das populações envolvidas.

É perfeitamente possível também fazer com que a experiência da Reserva da Jaqueira se aproxime ainda mais daquilo que Layrargues (2004) chama de "ecoturismo de base comunitária", cujos princípios são: 
- A comunidade local é a própria operadora do negócio ecoturístico, permitindo o desenvolvimento comunitário local, a emancipação política e favorecendo a distribuição de renda;

- A renda gerada permanece na comunidade local e é distribuída entre os trabalhadores da atividade;

- Há espaço para inclusão e inclusive ascensão social, já que a própria comunidade local é responsável pela gestão da atividade;

- O pacote ecoturístico envolve múltiplas dimensões: natureza, história e cultura como variáveis indissociadas [...];

- O turista imerge na realidade local, se impregna da vida cotidiana da coletividade, vivencia o envolvimento profundo e legítimo da rotina da comunidade local naquele espaço protegido. $O$ turista experimenta a alteridade de si com o outro como continuidade da natureza;

- O turista experimenta um contato direto com a realidade, com pouca mediação do guia.

Se formos seguir a conceituação proposta por Mourão (2001:25), podemos afirmar que o modelo turístico adotado na Reserva da Jaqueira une as características do ecoturismo com as do turismo cultural. $\mathrm{O}$ autor entende por ecoturismo "Programas com atividades ligadas ao meio ambiente natural, em geral amadoras, onde os participantes mantêm contato com a natureza. Atividades: Caminhadas, Observação de Aves, Etc.". O Turismo Cultural, por sua vez, é qualificado como "Programas direcionados a participantes interessados em conhecer costumes de determinado povo ou região. Atividades: Artesanato, Folclore, Etc.".

Leme e Neves (2005) desenvolveram pesquisa acerca do projeto de ecoturismo da Reserva da Jaqueira, concluindo que:

Com o projeto, [...] houve não só ganhos financeiros para a comunidade, mas culturais e sociais, com a valorização da cultura pataxó e do movimento de reivindicação, por parte dos membros da comunidade e dos turistas. Isso, somado à possibilidade de preservação da mata atlântica presente na área da reserva e que agora, com o projeto, é utilizada para a educação ambiental dos turistas.

Verificando os princípios da sustentabilidade apontados por Sachs apud Silveira (2000:90-91) ${ }^{41}$, Mendonça (2002) fez uma análise a respeito das facilidades e restrições para à sustentabilidade da ASPECTUR e do empreendimento ecoturístico da Reserva Pataxó da Jaqueira, chegando à seguinte conclusão:

[...] a ASPECTUR demonstra que: há proteção da natureza e da diversidade biológica através do respeito à capacidade de carga do ecossistema (sustentabilidade

\footnotetext{
${ }^{41}$ Ver conceito nas páginas 19 e 20 da presente monografia.
} 
ecológica); há garantias do direito de cidadania, distribuição eqüitativa de renda, ainda que insuficiente e irregular; encaminha-se célere para a autogestão (sustentabilidade social); há potencialização da afirmação cultural e do modo de vida; há forte participação dos associados nos processos decisórios; há resgate da auto-estima da comunidade através do sentimento do orgulho de ser Pataxó; há necessidade de melhorar o envolvimento da comunidade local (sustentabilidade cultural); há o manejo responsável dos recursos naturais; há falta de fluxo de visitantes que assegurem a sobrevivência exclusiva na atividade (sustentabilidade econômica); há precaução de não comprometer a qualidade ambiental e a experiência dos visitantes; há possibilidade de replicação da experiência ecoturística em outras aldeias Pataxó (sustentabilidade espacial). Ao consolidar-se o empreendimento pode vir a representar, de fato, uma alternativa de ecodesenvolvimento, contribuindo para a melhoria de vida e, imperativamente, caminhar para a autodeterminação Pataxó.

Em concordância com a opinião do autor supracitado, entendemos que, para que a experiência da Reserva da Jaqueira atinja uma condição ideal de sustentabilidade, ainda há muito que ser feito, mas o empreendimento parece estar no rumo certo. A capacidade de organização da comunidade indígena envolvida no empreendimento é surpreendente. Apesar de haver um grau razoável de empirismo e improvisação por parte dos índios no planejamento das ações e estratégias relacionadas ao turismo, o empreendimento parece estar sendo gerido de maneira eficaz dentro das possibilidades.

Se o poder público, principalmente a FUNAI, puder dar um maior apoio ao desenvolvimento dessa experiência, aumentam as chances de ela se firmar como um exemplo bem sucedido de turismo sustentável. Entretanto, a consolidação de um apoio efetivo ao turismo na Reserva da Jaqueira depende da regulamentação das atividades turísticas no interior das terras indígenas. Ainda que o órgão indigenista demonstre estar engajado nessa tarefa, sabe-se que a questão não é fácil de resolver, uma vez que estão proliferando em todas as regiões do país experiências turísticas em território indígena, algumas com maiores, outras com menores impactos ambientais e sócio-econômico-culturais. Desse modo, a regulamentação terá que ser bastante criteriosa para estabelecer em que condições o turismo pode ou não pode ocorrer.

Nos parece claro que, no caso da Reserva da Jaqueira, a proibição categórica da atividade turística não seria a solução mais adequada, mesmo porque os impactos produzidos têm sido mais positivos do que negativos. A FUNAI precisa ter cuidado 
para que, na tentativa de proteger da dominação local e privada um grupo indígena bastante integrado aos costumes da sociedade envolvente, como o Pataxó, não incorrer no erro de este próprio órgão indigenista acabar exercendo uma dominação sobre os índios, tolhendo a sua autodeterminação.

Caso fosse estabelecida a proibição indistinta do turismo em terras indígenas - o que não consideramos salutar - seria importante, pelo menos, que o Estado viabilizasse atividades econômicas alternativas que amenizassem a situação de carência dos índios. Há de se pensar que, caso a exploração do turismo na Reserva da Jaqueira seja obliterada, os Pataxó teriam que recorrer a outras possibilidades de obtenção de renda, escassas na região e de difícil viabilidade nas condições atuais em que vive o grupo, dispõe de pouquíssimos recursos financeiros e cujo espaço territorial em que habita é bastante diminuto.

Em relatório de viagem apresentado em dezembro de 2004 à Coordenação Geral de Patrimônio Indígena e Meio Ambiente (CGPIMA) da FUNAI, a antropóloga Júlia de Paiva e a técnica Ludmila Guerra chegam - acertadamente, do nosso ponto de vista - a seguinte conclusão:

(...) acreditamos que o programa de Ecoturismo hoje realizado na Reserva da Jaqueira pode servir como modelo de geração de trabalho e renda, e principalmente de resgate cultural para povos que tenham sofrido perdas significativas de sua cultura no processo de contato com a sociedade não-indígena. Nessas comunidades, o ecoturismo pode ser não só uma alternativa de sustentabilidade, mas um importante instrumento de afirmação étnica.

Cabe ressaltar também que, em muitas dessas comunidades que possuem maior tempo de contato e maior proximidade com a sociedade nacional, já existe presença não-indígena freqüente. Por isso, talvez seja mais proveitoso e menos danoso às comunidades indígenas que, nesse contexto, a preocupação da FUNAI se dê no sentido de organizar e acompanhar essa relação do que proibir uma atuação que já acontece, e que dificilmente poderia ser revertida. ${ }^{42}$

Assim sendo, entende-se aqui que seria bastante razoável a transformação da experiência ecoturística da Reserva Pataxó da Jaqueira em um projeto piloto de ecoturismo em terras indígenas a ser monitorado e avaliado durante um determinado tempo, a fim de que se possa ter um conhecimento mais apurado das conseqüências que tal atividade pode acarretar.

\footnotetext{
${ }^{42}$ GUERRA, Ludmila M. da Costa; PAIVA, Júlia de. Relatório de Viagem. Documento de circulação restrita à Fundação Nacional do Índio. 12 a 17 de dezembro de 2004.
} 


\section{BIBLIOGRAFIA}

AGOSTINHO, Pedro. Bases para o estabelecimento da reserva Pataxó. Revista de Antropologia, São Paulo, v. 23, p. 19-29, 1980.

AGUIAR, Leila B. Os Sítios Urbanos como Atração Turística: o caso de Porto Seguro. In: Instituto Virtual do Turismo (IVT). Caderno Virtual de Turismo. Vol. 3, no 1, 2003. p. 10-17. Disponível em: www.ivt.coppe.ufrj.br/caderno/ojs/include/getdoc.php?id=90\&article=28\&mode=pdf Acesso em 08/01/2007.

AMORIM, Siloé S. de. Notas etnográficas: a construção da auto-imagem de povos indígenas surgidos - Os Tumbalalá, os Kalankó e os Karuazu, Kóiupanká e Catókinn. Disponível em: <http://www.studium.iar.unicamp.br/13/5.html?studium=2.html>. Acesso em: 15 jan. 2006.

ALMEIDA, Jacione. A problemática do Desenvolvimento Sustentável. In: BECKER, Dinizar F. Desenvolvimento Sustentável: necessidade e/ou possibilidade? - 4. ed. - p. 21-29. Santa Cruz do Sul: EDUNISC, 2002.

ARAÚJO, Cristina P. de. Turismo e Desenvolvimento Local. FAU/USP, 2002.

ARRUTI, José M. A. Morte e Vida do Nordeste Indígena: a emergência étnica como fenômeno histórico regional. Estudos Históricos, Rio de Janeiro: APDOC, v. 8, n. 15, p. 57-94, 1995.

Disponível em http://www.cpdoc.fgv.br/revista/arq/165.pdf. Acesso em 20/07/2006.

ASPECTUR - ASSOCIAÇÃO PATAXÓ DE ECOTURISMO. PROJAQ - Programa de Desenvolvimento Sustentável e Preservação da Mata Atlântica na Reserva Indígena Pataxó da Jaqueira. Eunápolis-BA, 2007.

BAGGIO, Anery J. Ecoturismo: alternativa sustentável de valorização do patrimônio natural e cultural da Terra Indígena de Mangueirinha-PR. Dissertação apresentada como requisito parcial para a obtenção do título de Mestre em Ciências Sociais Aplicadas - Universidade Estadual de Ponta Grossa, Ponta Grossa-PR, 2006. (acessada através do Processo 0024/2007/CGEPFUNAI). Mimeografado.

BERGAMO, Mônica. Dança da Chuva. Folha de São Paulo. Caderno Ilustrada, p. E2. São Paulo, 03 de julho de 2006.

BRASIL, Sérgio A. Programa de Turista: Aldeias do Monte Pascoal, no sul da Bahia, abrem-se ao turismo para resgatar as tradições e preservar o que restou da Mata Atlântica na região. Revista HOST - hospitalidade \& turismo sustentável. Ano 3, v. 13, p. 22-29, abr./maio 2006.

BRASIL, Embratur. Diretrizes para uma política nacional de ecoturismo. [Coordenação de Silvio M. Barros II e Denise H. M. de La Penha]. Brasília, 1994.

BRASIL, Ministério do Turismo. Programa de Regionalização do Turismo - Roteiros do Brasil: Sustentabilidade Sociocultural - Princípio Fundamental. Brasília, 2006. Disponível em: <http://institucional.turismo.gov.br/regionalizacao/pdf/Sustentabilidade_Sociocultural.pdf.>. Acesso em 22/01/2007. 
BRASILEIRO, Sheila, Políticas oficiais de conservação ambiental: nova modalidade de subordinação dos índios? In: RICARDO, Fany (org.). Terras Indígenas e Unidades de Conservação: o desafio das sobreposições. São Paulo: Instituto Socioambiental, 2005.

BURMAN, Grazia; Santana, Marivone. Porto Seguro na Dianteira do Turismo Baiano. Bahia Análise e Dados n 3. Salvador: CEI, 1992, v. 2, pp. 65-69.

CAMARGO, Adilson. Parceria leva crianças à aldeia de Avaí. In: JC Regional. Bauru: 14 abr. 2006. p 15.

CARDOSO, Juliana de Souza. O Resgate da Identidade como Estratégia de Sobrevivência entre os Índios Pataxó. Dissertação (Mestrado em Psicologia Social) - Universidade Federal do Rio de Janeiro, Rio de Janeiro, 2000.

COHN, Clarice. Culturas em Transformação: os índios e a civilização. São Paulo: Perspectiva, v.15, no 2, p.36-42. abr./jun. 2001.

COMISSÃO BRUNDTLAND. Nosso Futuro Comum. Rio de Janeiro: Fundação Getúlio Vargas, 1991.

CONSELHO INDIGENISTA MISSIONÁRIO - CIMI. Assembléia da Frente de Resistência Pataxó fortalece a organização política do povo Pataxó no Monte Pascoal. Porantim, Brasília, v. 25, n. 256, p. 11, jun./jul. 2003.

Coroa Vermelha está virando favela. Jornal A Tarde. Salvador-BA, 23/11/2003.

DIAS, Reinaldo. Turismo Sustentável e Meio Ambiente. São Paulo: Atlas, 2003.

ESPÍRITO SANTO, Marco Antônio do. Diagnóstico Socioeconômico da comunidade Pataxó da Coroa Vermelha. FUNAI, Brasília, 1998.

FARIA, Ivani F. de. Ecoturismo: etnodesenvolvimento e inclusão social no Amazonas. In: PASOS. Revista de Turismo y Patrimonio Cultural. Vol. 3, nº 1, págs. 63-77. 2005a.

FARIA, Ivani F. de. Ecoturismo Indígena e Valorização do Patrimônio na Região do Alto Rio Negro. In: Noticias de Antropología y Arqueología. 2005b. Disponível em:

<http://www.naya.org.ar/turismo/articulos/ivani_ferreira.htm>

FIALHO, Vânia. Configurando a mobilização indígena no Nordeste brasileiro. Disponível em <http://www.comciencia.br/reportagens/2005/04/11.shtml>. Acesso em: 9 ago. 2005.

FIGGIS, Penélope. Prefácio. In: WEARING, Stephen; NEIL, John. Ecoturismo: impactos, potencialidades e possibilidades. 1. ed. Barueri-SP: Manole, 2001.

FIGUEIREDO, Antônio M. L. A Função Turística do Patrimônio: questionamentos sobre a idéia de sustentabilidade do turismo cultural. In: IVT. Caderno Virtual de Turismo no 18, dez. 2005. Disponível em: <http//www.ivt-rj.net>. Acesso em: 16 fev. 2006.

FOLHA dE SÃO PAULO. Tribo Pataxó Apresenta Seus Costumes em Reserva. Turismo. p. F1. 07/09/2006. 
FREIRE, José R. B. O Canibalismo Turístico. Artigo publicado em 19 dez. 2005. Disponível em: <http://www.ipol.org.br/imprimir.php?cod=352>. Acesso em: 21/06/2006.

FUNDAÇÃO NACIONAL DO ÍNDIO. Brasil Indígena. Ano III, n 3, jul./ ago./ set de 2006.

FUNADAÇÃO NACIONAL DO ÍNDIO. Conferência Nacional dos Povos Indígenas, em 12 a 19 de abril de 2006, Brasília-DF - Documento Final. Brasília: FUNAI/CGDTI, 2006.

FUNDAÇÃO NACIONAL DO ÍNDIO - NÚCLEO DE APOIO LOCAL DE PORTO SEGURO. Auê Pataxó. $1^{\mathrm{a}}$ edição. Porto Seguro-BA: out./nov. de 2006.

GALVÃO, Eduardo. Áreas Culturais Indígenas do Brasil: 1900/1959. In: Encontro de Sociedades. Rio de Janeiro: Paz e Terra, 1979. pp. 193-228.

GAMA, Hélio F. L. N. da. Turismo e Sustentabilidade: um olhar sociológico sobre os lugares Ponta do Corumbau, Brasil e Havana, Cuba. Tese (Doutorado em Sociologia) - Universidade de Brasília, Brasília, 2005.

GIMENEZ, Célia B.; COELHO, Raimundo S. Bahia Indígena: encontro de dois mundos verdade do descobrimento. Rio de Janeiro: Topbooks, 2005.

GORGULHO, Silvestre. O Índio, a Natureza e o Turismo. Artigo publicado no website Estudos Turísticos em 19/04/2002. Disponível em:

<http://www.etur.com.br/conteudocompleto.asp?idconteudo=765>. Acesso em: 06/07/2002.

GRÜNEWALD, Rodrigo A. Os Índios do Descobrimento: Tradição e Turismo. Rio de Janeiro: Contra Capa, 2001. v. 1. 224 p.

GRÜNEWALD, Rodrigo A. A Reserva da Jaqueira: Etnodesenvolvimento e Turismo. In: RIEDL, Mário; ALMEIDA, Joaquim A.; VIANA, Andyara L. B.. (Org.). Turismo Rural: Tendências e Sustentabilidade. Santa Cruz do Sul: EDUNISC, 2002, p. 205-230.

GRÜNEWALD, Rodrigo A. Turismo e Etnicidade. Horizontes Antropológicos, Porto Alegre, v. 9, $\mathrm{n}^{\circ} 20$, p.15-29, out 2003.

GRÜNEWALD, Rodrigo A. Turismo e o Resgate da Cultura Pataxó. In: Álvaro Banducci Jr.; Margarita Barretto. (Org.). Turismo e Identidade Local. $5^{a}$ ed. Campinas: Papirus, 2005, p. 127148.

GTC AMAZÔNIA - GRUPO TÉCNICO DE COORDENAÇÃO DA AMAZONIA. Manual Indígena de Ecoturismo. Brasília. NAC - Núcleo de Arte e Cultura, 1997.

GUERRA, Ludmila M. da Costa; PAIVA, Júlia de. Relatório de Viagem. Documento de circulação restrita à Fundação Nacional do Índio. 12 a 17 de dezembro de 2004.

HECK, Egon Dionísio. Pataxó do Monte Pascoal: a resistência das retomadas. Porantim, Brasília, v. 24, n. 248, p. 8-9, set. 2002.

KRIPPENDORF, Jost. Sociologia do Turismo: para uma nova compreensão do lazer e das viagens. Rio de Janeiro: Civilização Brasileira, 1989. 
LAC, Flávia. O Turismo e os Kaingang na Terra Indígena de Irai/RS. Dissertação (Mestrado em Antropologia Social). Universidade Federal do Paraná - UFPR. Curitiba, 2005.

LAKATOS, Eva M. Sociologia Geral. São Paulo: Atlas, 1991.

LAYRARGUES, Philippe P. A Função Social do Ecoturismo. Boletim técnico do SENAC, Rio de Janeiro, v. 30, n. 1, p. 39-45, 2004.

LEAL, Renata. Programa de Índio: novo roteiro de turismo leva viajantes para conhecer o dia-adia de uma aldeia na borda do Parque Indígena do Xingu. Revista Época, 9 de maio de 2005, Turismo, pp. 88-90.

LEME, Fernanda B. M.; NEVES, Sandro C. Planejamento, Turismo e Cultura: o contato com o outro como fator de sustentabilidade para movimentos identitários. In: Noticias de Antropología y Arqueología. 2005. Disponível em:

<http://www.naya.org.ar/turismo/congreso2005/ponencias/Fernanda_Beraldo_Maciel_Leme.htm> Acesso em 31/01/2007.

LEME, Fernanda B. M.; Trevizan, Salvador D. P. O Resgate da Identidade Cultural: meio para uma sustentabilidade local. In: Interações Revista Internacional de Desenvolvimento Local. Vol. 7, № 12, p. 101-110, Campo Grande-MS: UCDB, Mar. 2006.

LIMA, Ana Claudia; GITA, Ana. Trabalho com Populações Tradicionais. In: Melhores Práticas para o Ecoturismo. Manual MPE, Versão 1.0. Set, 2001. Disponível em www.funbio.org.br. Capturado em 13.11.2006.

LUÍNDIA, Luiza Elyane Azevedo. Ecoturismo en Sociedades Indígenas ¿Una Propuesta Sostenible? Paper apresentado na décima conferência da associação internacional para 0 estudo da propriedade comum, Oaxaca, México, 9 a 13 de agosto de 2004. Disponível em: <http://www.iascp2004.org.mx/downloads/paper_360.pdf.>. Acesso em 12/01/2007.

LUSTOSA, Edson. Índios em pé de guerra: turismo em terra indígena gera conflito e denúncias. Reportagem publicada no jornal Imprensa Popular. Porto Velho-RO, 21/03/2006. Disponível em: http://www.imprensapopular.com/see.asp?codnews=1910\&categoria=reportagem Acesso em: 04/07/2006.

MACEDO, Sérgio. Pataxós: a vida dos índios que receberam Cabral. Ecologia e Desenvolvimento, Rio de Janeiro, v. 2, nº. 14, p. 42-47, abr. 1992.

MAXIMILIANO, Príncipe de Wied-Neuwied. Viagem ao Brasil. Belo Horizonte: Itatiaia; São Paulo: Edusp, 1989. (Coleção Reconquista do Brasil. 2. Série; v.156)

MELO, Erick S. O. de, Turismo Sustentável em Áreas Indígenas: uma alternativa para a aldeia Guarani Araponga no município de Paraty/RJ. Monografia [Graduação: Bacharelado em Turismo]. Universidade Estácio de Sá. Rio de Janeiro, 2005.

MENDONÇA, Roberto Costa e Silva. Associação Pataxó de Ecoturismo - Reserva da Jaqueira, Porto Seguro, Bahia: facilidades e restrições para a sua sustentabilidade. Dissertação (Mestrado em Desenvolvimento Regional e Meio Ambiente) - Universidade Estadual de Santa Cruz, Ilhéus, 2002. 
MENDONÇA JÚNIOR, Érico P., GARRIDO, Inez M. D. A., VASCONCELLOS, Maria do Socorro M. O Turismo como Fator de Desenvolvimento Socioeconômico da Costa do Descobrimento - Bahia - Brasil. In: BAHIA ANÁLISE \& DADOS. SEI v.11, n.2, p.118-124. Salvador-BA: Setembro de 2001.

METRE, Léia. Ecoturismo em terras de índios Pataxó. Porã'duba, Brasília, v. 2, n. 19, p. 3, jul. 2002.

MMA/Instituto EcoBrasil. Programa Piloto de Ecoturismo em Terras Indígenas. Workshop. Bela Vista de Goiás-GO, 3 a 7 de março de 1997.

MOURÃO, Roberto M. F. Ecoturismo e Turismo Especializado: conceitos. In: Melhores práticas para o Ecoturismo. Manual MPE, Versão 1.0. Set, 2001. Disponível em www.funbio.org.br. Capturado em 13.11.2006.

MURICY, Ivana T. O Éden Terrestre: o consumo da cidade como mito. In: BAHIA ANÁLISE \& DADOS. SEI. v.11 n. 2. p.180-193. Salvador-BA: Setembro de 2001.

MUSEU DO ÍNDIO, Povos Indígenas do sul da Bahia: Posto Indígena Caramuru-Paraguaçu (1910-1967)/Sônia O. Coqueiro (Coord.), M. Elizabeth B. Monteiro, Sheila M. G. de Sá, Carlos A. M. Perez. Rio de Janeiro: Museu do Índio, 2002. - (Coleção Fragmentos da História do Indigenismo, 1).

OLIVEIRA, João Pacheco de. Uma etnologia dos "índios misturados"? Situação colonial, territorialização e fluxos culturais. Mana, v. 4, n.1, p. 47-77, abr. 1998,

OLIVEIRA, João Pacheco de.(Org.). A viagem da volta: etnicidade, política e reelaboração cultural no Nordeste indígena. Rio de Janeiro: Contra Capa, 1999.

OLIVEIRA, João Pacheco de. Três Teses Equivocadas Sobre o Indigenismo: em especial sobre os índios do Nordeste.

OURIQUES, Helton R. A produção do turismo: fetichismo e dependência. Campinas: editora Alínea, 2005.

PARAÍSO, Maria Hilda B. Os Capuchinhos e os Índios no Sul da Bahia: uma análise preliminar de sua atuação. In: Revista do Museu Paulista, São Paulo, v. XXXI, p. 148-196, 1986.

PARAÍSO, Maria Hilda B. Caminhos de Ir e Vir e Caminhos sem Volta: índios, estradas e rios no sul da Bahia. Dissertação [Mestrado em Ciências Sociais]. Salvador: UFBA, 1982.

PINHÃO, Ailson O.; Trevizan, Salvador D. P. Cultura e Turismo: imagem dos índios Tupinambá sobre Olivença. In: Revista Internacional de Desenvolvimento Local, Vol. 7, N. 11, p. 121-127, Set. 2005.

PIRES, Paulo dos Santos. Dimensões do Ecoturismo.. São Paulo: Editora SENAC, 2002.

RAMOS, Paulo Cezar M. A importância das Unidades de Conservação de Proteção Integral e as comunidades Pataxó no extremo-sul da Bahia. In: RICARDO, Fany (org.). Terras Indígenas e Unidades de Conservação: o desafio das sobreposições. São Paulo: Instituto Socioambiental, 2005. 
RIBEIRO, Darcy. Os Índios e a Civilização: a integração das populações indígenas no Brasil moderno. 5a ed. - Petrópolis: Vozes, 1986.

ROCHA, Diana Ribeiro. Informação $n^{\circ}$ 170/CAA/PGF/PFE-FUNAI/2006. Processo $n^{\circ}$ 08620.0812/PJ-FUNAI/2006.

ROCHA JUNIOR, Omar. Yes, nós também temos índios. Cadernos do CEAS, n. 111, Salvador, p. 38-48.

ROCHA JUNIOR, Omar. A Arte de ser Índio: os Pataxó e os turistas na Coroa Vermelha. Tese (Mestrado em Comunicação e Cultura Contemporâneas), Universidade Federal da Bahia, 1990.

SALVATI, Sérgio S. O Perfil do Ecoturista. Artigo publicado no website "Estudos Turísticos" em 21 nov. 2001. Disponível em:

<http://www.estudosturisticos.com.br/conteudocompleto.asp?IDConteudo=238>. Acessado em 21 set. 2003.

SAMPAIO, José Augusto L. Terras e Povos Indígenas do Nordeste: Notas para um Mapa da Fome. In: Mapa da Fome entre os Povos Indígenas no Brasil. INESC - PETI/MN - ANAÍ/BA, 1995.

SAMPAIO, José Augusto L. Relatório Circunstanciado de Identificação e Delimitação da Terra Indígena Coroa Vermelha. Brasília, FUNAI, 1996a.

SAMPAIO, José Augusto L. Especulação Imobiliária e os Pataxó de Coroa Vermelha. In: RICARDO, C. A. (Org.) Povos Indígenas no Brasil 1991/95 - Instituto Socioambiental: São Paulo, 1996b.

SAMPAIO, José A. L. Breve história da presença indígena no extremo sul baiano e a questão do território Pataxó de Monte Pascoal. In: ESPÍRITO SANTO, Marco Antônio do (org.). Política indigenista: Leste e Nordeste brasileiros. Brasília: FUNAI, 2000.

SAMPAIO, José Augusto L. Pataxó: retomadas na rota do quinto centenário. Povos indígenas no Brasil: 1996/2000, p. 715-721. São Paulo: Instituto Socioambiental, 2000.

SEABRA, Giovanni. Ecos do Turismo: o turismo ecológico em áreas protegidas. Campinas: Papirus, 2001.

SIMBIOS - Consultoria e Projetos LTDA. Estudo de Impacto Ambiental do Memorial do Encontro. Porto Seguro, 1999. v 2.

SILVA, Marcelo S.; FERNANDES, Fábio M. Turismo, Desenvolvimento Local e Pobreza no Município de Porto Seguro-BA. In: Revista Espaço Acadêmico. Ano V - N051 - Ago./2005. Disponível em: <http://www.espacoacademico.com.br/051/51fernandes_silva.htm>.

SILVEIRA, A. Desenvolvimento Sustentável e Atividade Turística. In: RODRIGRES, Adyr Balastreri. (Org.) - Turismo e Desenvolvimento Local. 2 ed. São Paulo: Editora Cortês, 1999.

SOWERBY, Valeria Poey. Turismo em Comunidades Indígenas. Disponível em:

< http://www.indigenas.bioetica.org/inves14.htm>. Acesso em 22 mar. 2006. 
URRY, John. O Olhar do Turista: lazer e viagens na sociedade contemporânea. 3 ed. São Paulo: Studio Nobel, 1996.

VALLERIO, Ciça. Quarup dos Cuicuros, em São Paulo. O Estado de São Paulo. Caderno Viagens \& Aventura, p. V6. São Paulo, 11 de abril de 2006.

VALLE, Claúdia Netto do. Sou brasileiro, baiano, pataxó. Tese (Doutorado) - Ciências Sociais (Antropologia) / PUC-SP. São Paulo: PUC-SP, 2000.

VERACRUZ FLORESTAL LTDA. As Comunidades Indígenas da Região Sul da Bahia: diagnóstico sócio-econômico. Porto Seguro, 1995. 45 p. Mimeografado.

VIANNA, Fernando L. B. Razão indigenista e razão conservacionista desafiadas no sul da Bahia. In: RICARDO, Fany (org.). Terras Indígenas e Unidades de Conservação: o desafio das sobreposições. São Paulo, Instituto Socioambiental, 2005.

VIEIRA, José Glebson. O eu e outro: o turismo étnico no grupo indígena Potyguara da Paraíba Nordeste brasileiro. In: Il Congreso Virtual de Turismo, 2003. Disponível em:

<http://www.naya.org.ar/turismo/congreso2003/ponencias/Jose_Glebson_Vieira.htm>.

XAVIER, Adriana C. O Papel Social do Turismo. In: Caderno Virtual de Turismo. Instituto Virtual de Turismo. Vol. 6. №1. Rio de Janeiro, mar. 2006. p. 9-15. Disponível em: <http://www.ivt-rj.net>. Acessado em: 10/06/2006.

WEARING, Stephen; NEIL, John. Ecoturismo: impactos, potencialidades e possibilidades. 1. ed. Barueri-SP: Manole, 2001.

ZARUR, Fernando. Turismo em Terras Indígenas. Disponível em:

<http://www.brasiloeste.com.br/noticia/174/>. Acesso em: 21/05/2005. Artigo publicado em 17/09/2002.

\section{Sites consultados:}

Associação Guarani Nhe'e Porã

<http://www.culturaguarani.hpg.ig.com.br/> Acesso em 10/01/2007.

Associação Pataxó de Ecoturismo

$<$ http://www.rabarsa.com/pataxo/> Acesso em 08/01/2007.

Bahiatursa

<http://www.bahiatursa.ba.gov.br/> Acesso em: 08/01/2007.

Descubra Minas

<http//www.descubraminas.com.br/destinosturisticos/lst_circuito.asp> Acesso em:

19/05/2006.

Instituto Socioambiental.

<www.socioambiental.org>. Acesso em 09/01/2007.

Secretaria Municipal de Turismo de Porto Seguro-BA

<http://www.portosegurotur.com.br/porto_lazer-jaqueira2.htm> Acesso em: 08/01/2007. 
ANEXOS 


\section{ILUSTRAÇÕES}

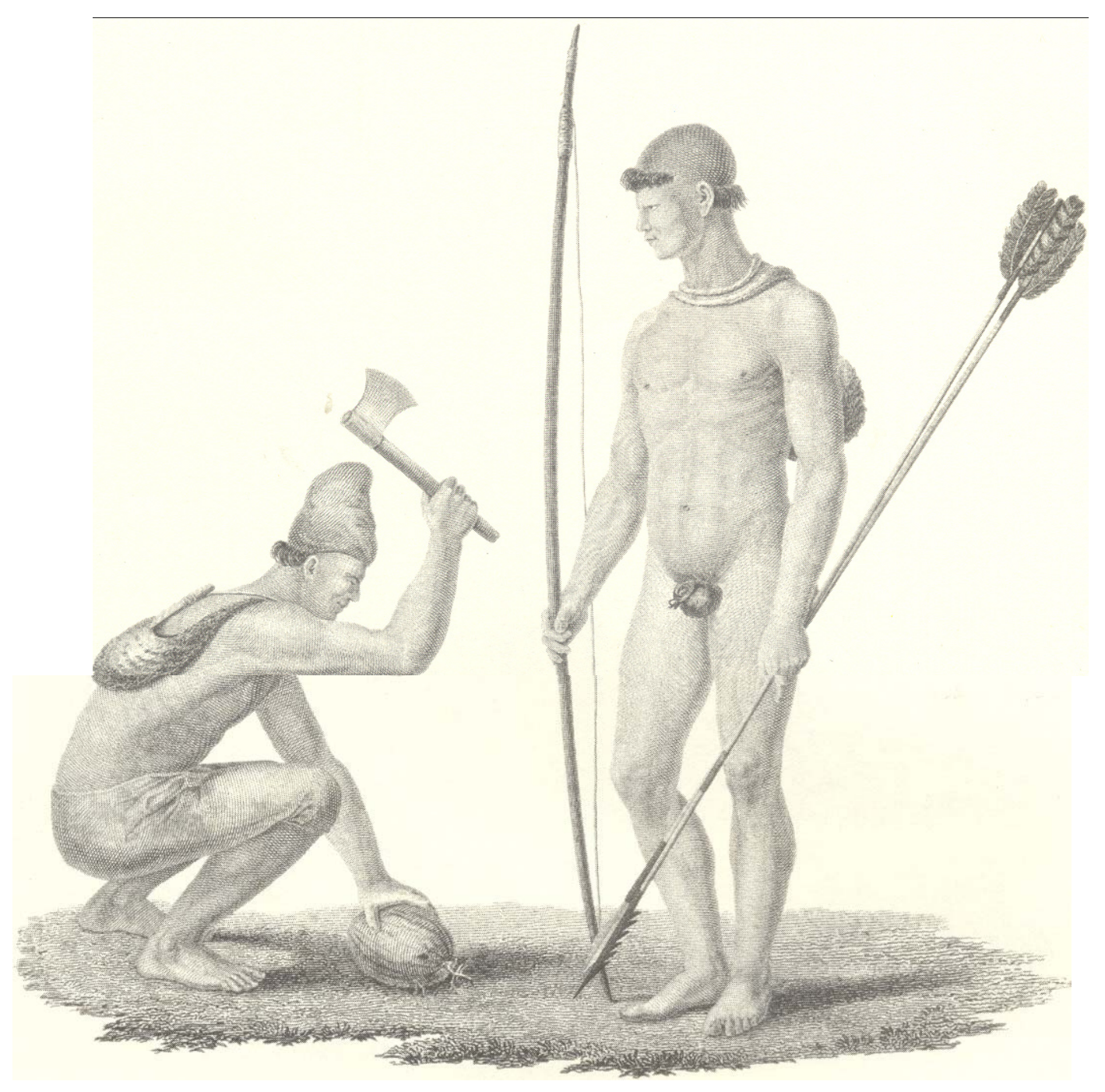

Na gravura reproduzida logo acima*, pertencente hoje ao acervo do Arquivo Nacional, o príncipe alemão Maximiliano de Wied-Newied retrata os índios Pataxó do Rio Pardo na época em que esteve em contato com esse grupo (1821-1822). Nota-se que os índios acima retratados diferem muito em aparência dos seus atuais descendentes.

\footnotetext{
* A gravura reproduzida nesta página foi copiada da seguinte publicação:

MUSEU DO ÍNDIO, Povos Indígenas do sul da Bahia: Posto Indígena Caramuru-Paraguaçu (1910-1967)/Sônia O. Coqueiro (Coord.), M. Elizabeth B. Monteiro, Sheila M. G. de Sá, Carlos A. M. Perez. Rio de Janeiro: Museu do Índio, 2002. - (Coleção Fragmentos da História do Indigenismo, 1). p.23.
} 


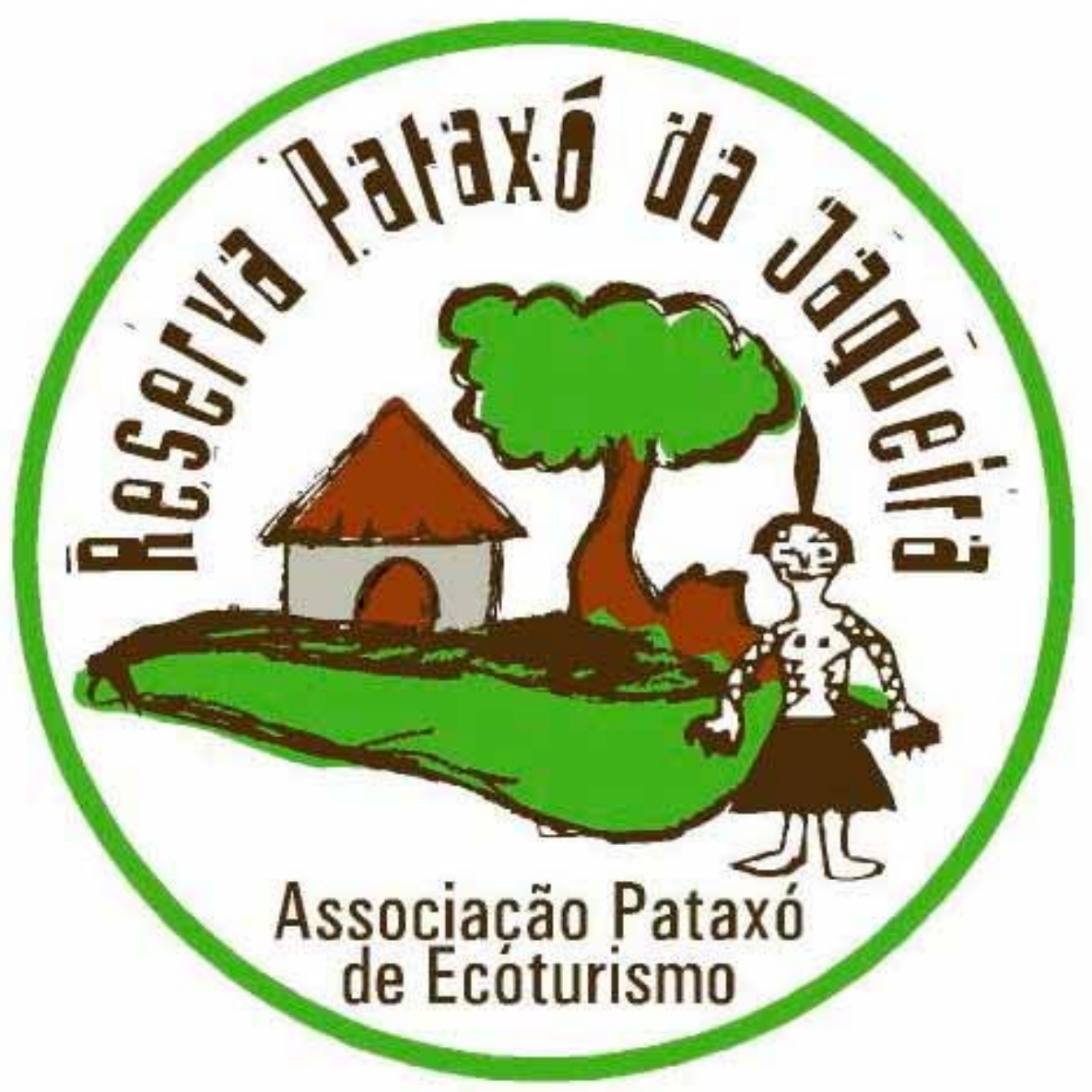

Acima se vê o emblema** da ASPECTUR (Associação Pataxó de Ecoturismo), responsável pela administração do empreendimento turístico da Reserva Pataxó da Jaqueira.

\footnotetext{
** Retirado do endereço eletrônico: <http://www.rabarsa.com/pataxo/> Acesso em 08/01/2007.
} 


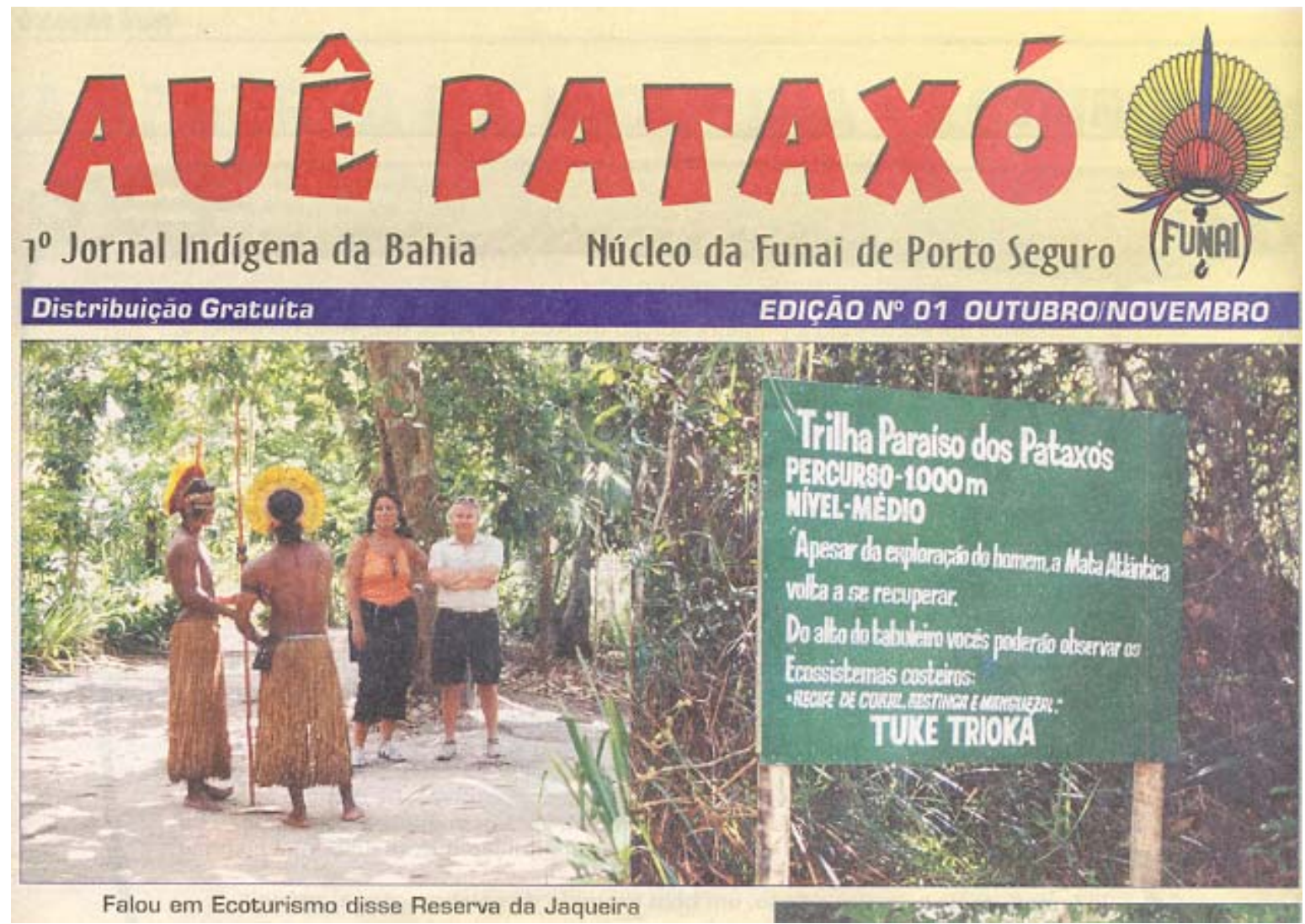

Edição do jornal "Auê Pataxó" publicado pelo Núcleo de Apoio Local da Funai em Porto Seguro-BA. Logo na capa se vê uma propaganda do ecoturismo na Reserva da Jaqueira. 


\section{MAPA DA TERRA INDÍGENA COROA VERMELHA*}

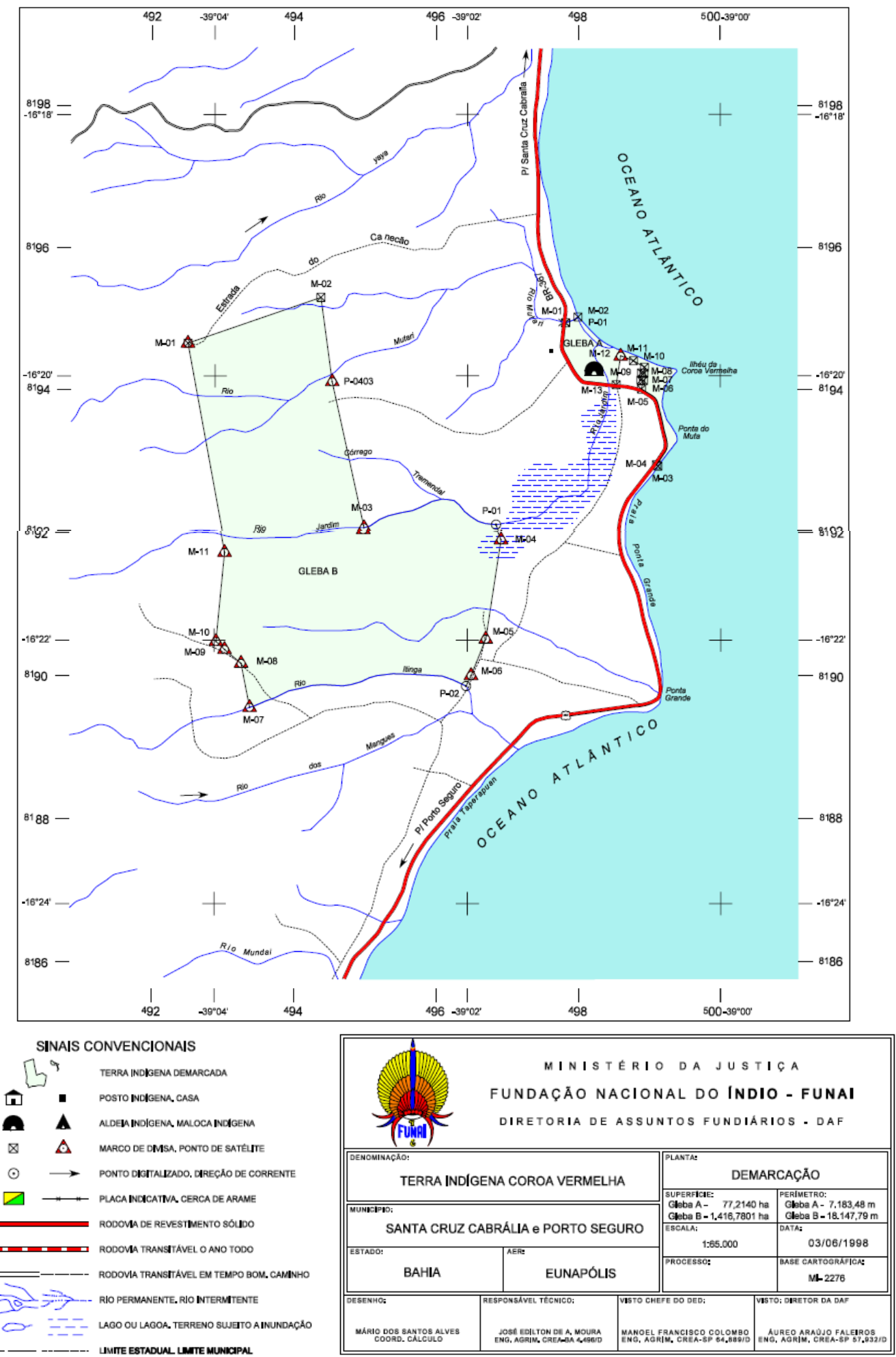

\footnotetext{
* Mapa elaborado pela Diretoria de Assuntos Fundiários da FUNAI e copiado através do sistema de intranet deste órgão. Obs: A TI de Coroa Vermelha encontra-se atualmente sob jurisdição do Núcleo de Apoio Local de Porto Seguro, subordinado a Administração Executiva Regional (AER) de Ilhéus-BA, sendo que a AER de Eunápolis, citada no documento acima foi extinta. A Reserva da Jaqueira está situada no interior da Gleba B desta TI.
} 


\section{FOTOGRAFIAS}
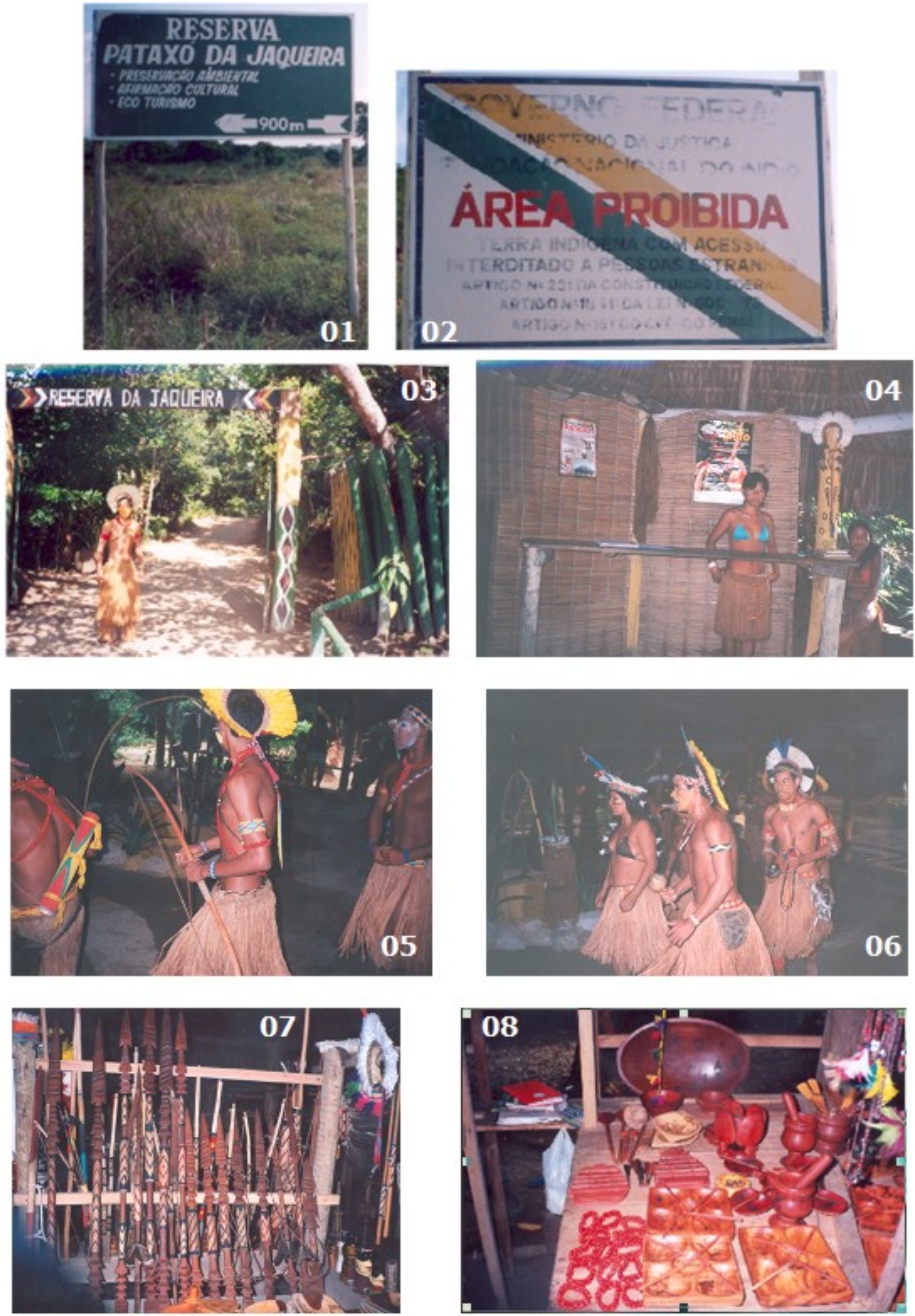

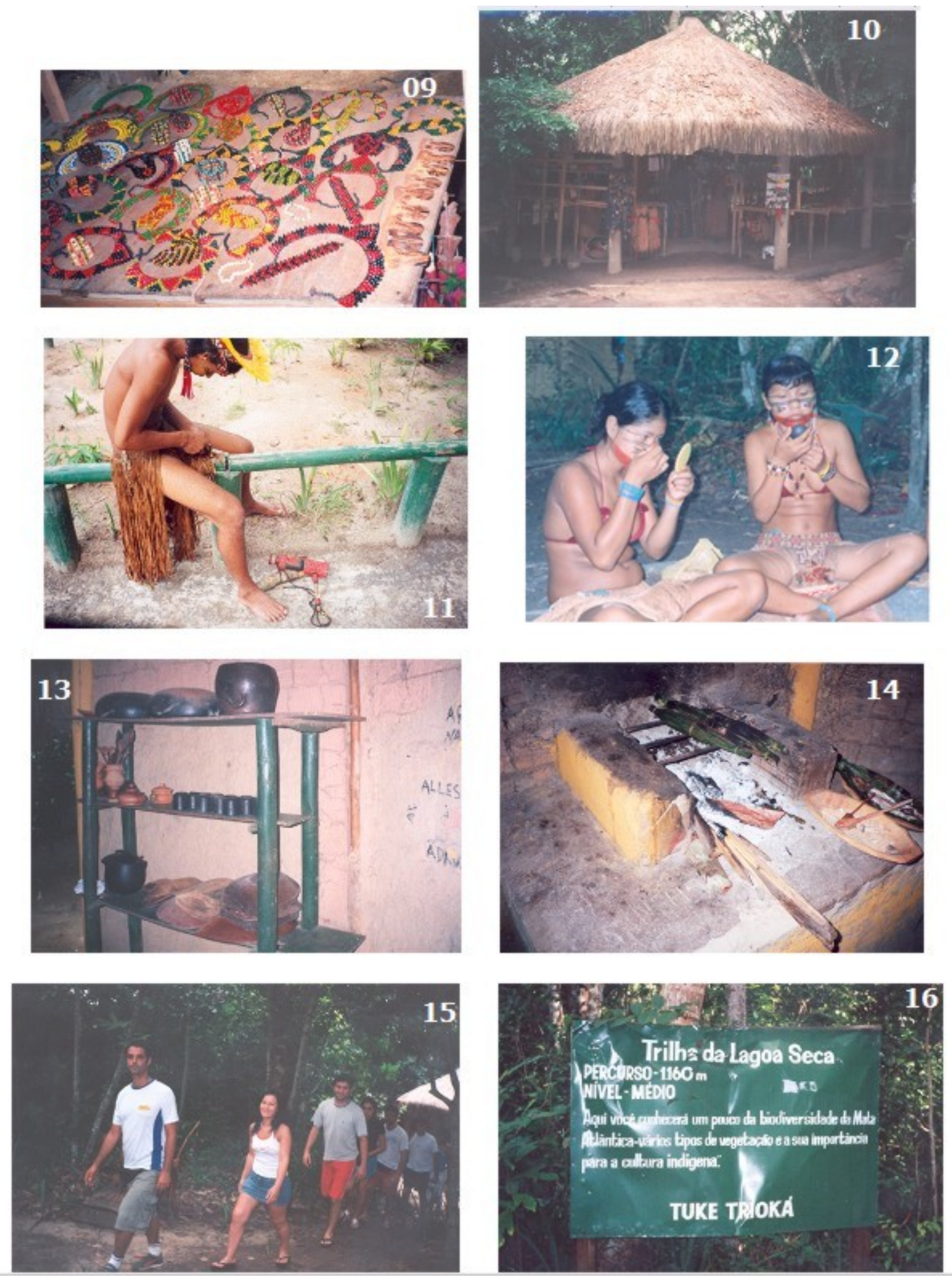

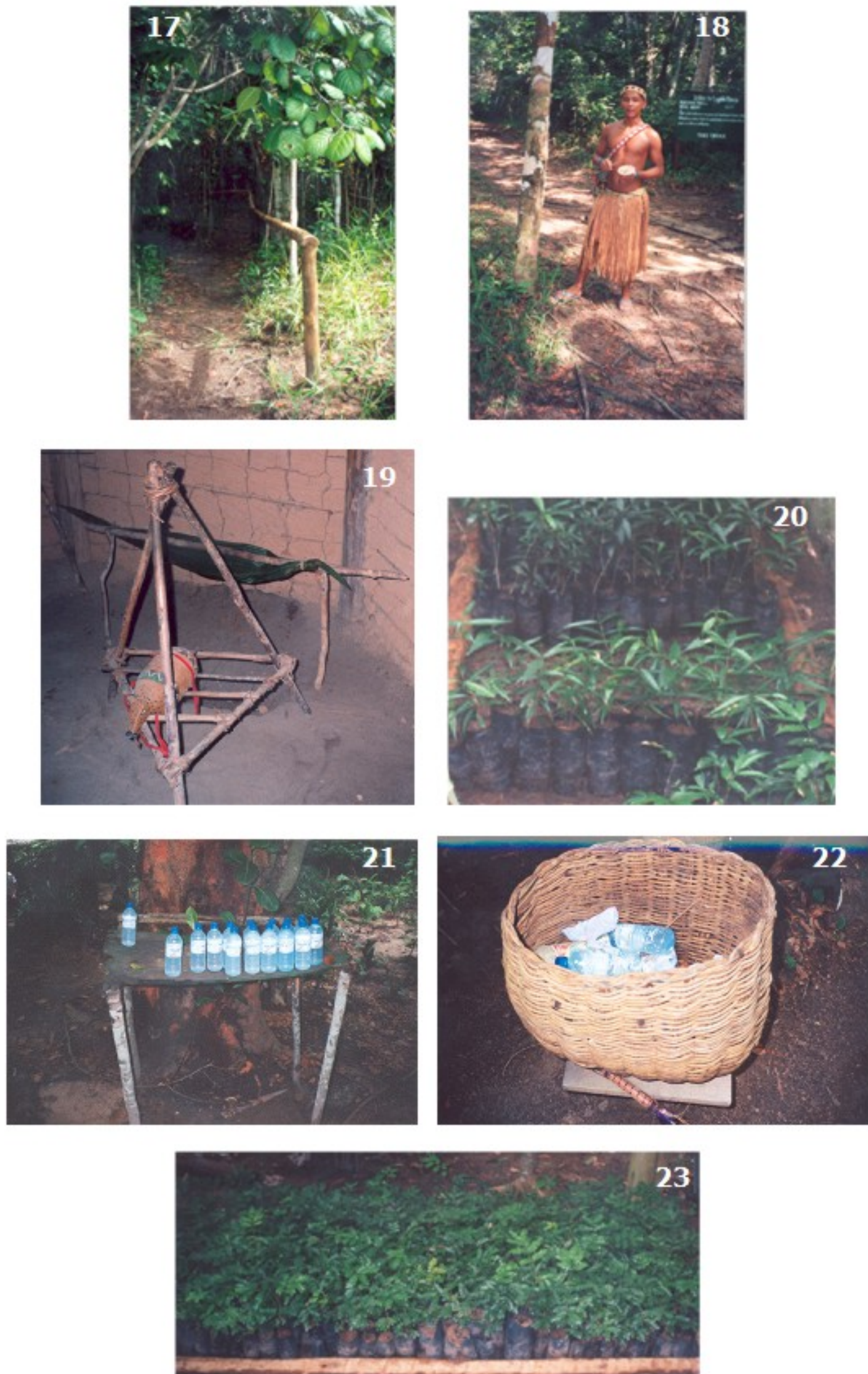

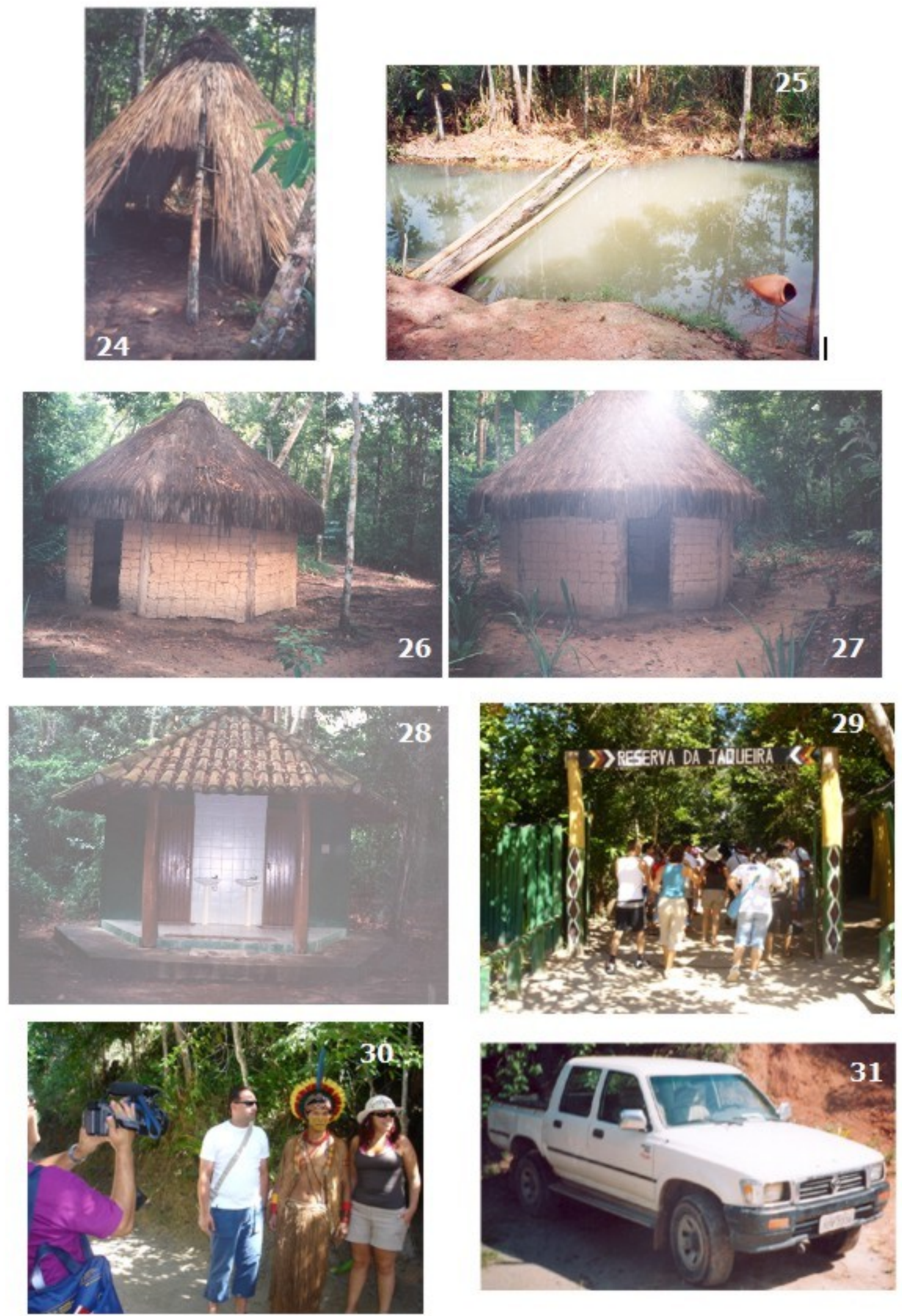


\section{LEGENDAS DAS FOTOGRAFIAS *}

1- Placa de sinalização localizada na estrada que leva à Reserva da Jaqueira.

2- Placa de sinalização de território indígena colocada pela FUNAI na entrada da reserva.

3- Portal de entrada da Reserva da Jaqueira.

4- Centro de recepção ao turista na entrada da reserva.

5 e 6 - Índios dançando o awê para os turistas.

7 - Lanças produzidas pelos índios e colocadas à venda para os turistas.

8 - Artigos em madeira vendidos no centro de artesanato.

9 - Colares expostos para a venda no centro de artesanato.

10 - Fachada do Centro de Artesanato Indígena.

11 - Índio Pataxó confeccionando peça de artesanato em madeira.

12 - Índias se pintando para a dança.

13 - Prateleira com utensílios de cozinha utilizados pelos Pataxó.

14 - Peixe assado na folha de patióba. Especialidade da culinária Pataxó.

15 - Turistas percorrendo uma das trilhas na mata.

16 - Placa de sinalização e informação de uma das trilhas ecológicas.

17 - Entrada de uma das trilhas na mata, onde se nota a existência de um corrimão.

18 - Índio Pataxó demonstra aos turistas o processo de produção de uma essência aromática feita com substratos extraídos de uma árvore da Mata Atlântica.

19 - Réplica de armadilha utilizada para caçar animais.

20 e 23 - Viveiro de mudas que serão utilizadas no reflorestamento da Mata Atlântica.

21 - Banca de venda de água mineral para os turistas.

22 - Cesto de palha onde é descartado o lixo produzido pelos visitantes.

24 - Cabana construída em estilo indígena com madeira e coberta com piaçava.

25 - Córrego que passa dentro da reserva.

26 e 27 - Kijemes temáticos.

28 - Sanitários para o uso dos turistas.

29 - Turistas entrando na Reserva Pataxó da Jaqueira.

30 - Turistas fazendo filmagem junto com um indígena.

31 - Caminhonete doada pela empresa Veracel Celulose para a ASPECTUR, estacionada no pátio em frente à Reserva da Jaqueira.

\footnotetext{
* Todas as fotografias foram tiradas no ano de 2006. A foto $\mathrm{n}^{\circ} 12$ foi cedida pela antropóloga Leila Soto Maior; as fotos de $\mathrm{n}^{\circ}$ 29 e 30 foram cedidas pelo geógrafo Sandoval Amparo. As demais fotografias foram tiradas pelo autor desta monografia.
} 